\title{
The Effect of State Taxes on the Geographical Location of Top Earners: Evidence from Star Scientists
}

\author{
Enrico Moretti \\ University of California, Berkeley \\ Daniel Wilson \\ Federal Reserve Bank of San Francisco
}

March 2017

Working Paper 2015-06

http://www.frbsf.org/economic-research/publications/working-papers/wp2015-06.pdf

\section{Suggested citation:}

Moretti, Enrico, and Daniel Wilson. 2017. "The Effect of State Taxes on the Geographical Location of Top Earners: Evidence from Star Scientists.” Federal Reserve Bank of San Francisco Working Paper 2015-06. http://www.frbsf.org/economicresearch/publications/working-papers/wp2015-06.pdf

The views in this paper are solely the responsibility of the authors and should not be interpreted as reflecting the views of the Federal Reserve Bank of San Francisco or the Board of Governors of the Federal Reserve System. 


\title{
The Effect of State Taxes on the Geographical Location of
}

\section{Top Earners: Evidence from Star Scientists}

\author{
By ENRICO MORETTI AND DANIEL J. WILSON*
}

We quantify how sensitive is migration by star scientist to changes in personal and business tax differentials across states. We uncover large, stable, and precisely estimated effects of personal and corporate taxes on star scientists' migration patterns. The long run elasticity of mobility relative to taxes is 1.8 for personal income taxes, 1.9 for state corporate income tax and -1.7 for the investment tax credit. While there are many other factors that drive when innovative individual and innovative companies decide to locate, there are enough firms and workers on the margin that state taxes matter.

\footnotetext{
* Moretti: Department of Economics, University of California, Berkeley, 619 Evans Hall \#3880, Berkeley, CA 94720-3880 (moretti@berkeley.edu). Wilson: Federal Reserve Bank of San Francisco, 101 Market St., Mail Stop 1130, San Francisco, CA 94105 (daniel.wilson@sf.frb.org). We are thankful for very helpful comments received from the editor, four referees, and seminar participants at Barcelona GSE, Berkeley, Federal Reserve Bank of San Francisco, IZA, National Tax Association, New York Fed, Stanford GSB, and the University of Hawaii, and also from discussions by Jon Bakija, Jorge De La Roca, Alex Gelber, Juan Carlos Suárez Serrato and Danny Yagan. Yifan Cao provided excellent research assistance. Moretti gratefully acknowledges financial support from Microsoft. The views expressed in the paper represent those of the authors and do not necessarily represent the views of the Federal Reserve Bank of San Francisco or the Federal Reserve System. The authors declare that they have no relevant or material financial interests that relate to the research described in the paper.
} 


\section{Introduction}

In the United States, personal taxes vary enormously from state to state. These geographical differences are particularly large for high income taxpayers. Figure 1 shows the average tax rate (ATR) component due solely to state individual income taxes for a taxpayer with income at the $99^{\text {th }}$ percentile nationally in 2010. ${ }^{1}$ The ATRs in California, Oregon, and Maine were $8.1 \%$, 9.1\%, and 7.7\%, respectively. By contrast, Washington, Texas, Florida, and six other states had 0 income tax. ${ }^{2}$ Large differences are also observed in business taxes. As shown in Figure 2, Iowa, Pennsylvania, and Minnesota had corporate income taxes rates of $12 \%, 9.99 \%$, and $9.8 \%$, respectively, while Washington, Nevada, and three other states had no corporate tax at all. And not only do tax rates vary substantially across states, they also vary within states over time. Figure 3, for instance, shows how states’ individual income ATRs changed during various intervals spanning 1977 to 2010. Corporate tax rates exhibit similar within-state variation (see Appendix Figure 1).

If workers and firms are mobile across state borders, these large differences over time and place have the potential to significantly affect the geographical allocation of highly skilled workers and employers across the country. The literature on the effect of taxes on the labor market has largely focused on how taxes affect labor supply, and by and large it has ignored how taxes might affect the geographical location of workers and firms. This is surprising because the effect of state taxes on the ability of states to attract firms and jobs figures prominently in the policy debate in the U.S.

Many states aggressively and openly compete for firms and high-skilled workers by offering low taxes. Indeed, low-tax states routinely advertise their favorable tax environments with the explicit goal of attracting workers and business activity to their jurisdiction. Between 2012 and 2014, Texas ran TV ads in California, Illinois and New York urging businesses and high-income taxpayers to relocate. Governor Rick Perry visited dozens of California companies to pitch Texas' low taxes, famously declaring: “Texas rewards success with no state income tax.” Similarly, Kansas has paid for billboards in Midwestern states to advertise its recent tax cuts. Wisconsin Governor Scott Walker has called upon Illinois and Minnesota employers to “escape to Wisconsin.” Louisiana and Indiana have followed similar strategies. In the 2014 election cycle, state taxes and their effect on local jobs were a prominent issue in many gubernatorial races.

\footnotetext{
${ }^{1}$ We map here the average tax rate component due solely to state income taxes, rather than the full average tax rate which accounts additionally for federal income taxes, in order to illustrate the ATR differences driven by state tax policy differences. Our empirical analyses in the remainder of the paper utilize the full ATR.

${ }^{2}$ One of those six, Alaska, is not shown on the map.
} 
But despite all the attention from policy makers and voters, the effect of taxes on the geographical location of high earners and businesses remains poorly understood because little systematic evidence on their effects is available. As noted in a recent paper by Kleven, Landais and Saez (2013) there is "very little empirical work on the effect of taxation on the spatial mobility of individuals, especially among high-skilled workers”.

In this paper, we seek to quantify how sensitive is internal migration by high-skilled workers to personal and business tax differentials across U.S. states. Personal taxes might shift the supply of workers to a state: states with high personal taxes presumably experience a lower supply of workers for given before-tax average wage, cost of living and local amenities. Business taxes might shift the local demand for skilled workers by businesses: states with high business taxes presumably experience a lower demand for workers, all else equal.

We focus on the locational outcomes of star scientists, defined as scientists - in the private sector as well as academia and government - with patent counts in the top 5\% of the distribution. Using data on the universe of U.S. patents filed between 1976 and 2010, we identify their state of residence in each year. We compute bilateral migration flows for every pair of states (51x51) for every year. We then relate bilateral outmigration to the differential between the destination and origin state in personal and business taxes in each year. To this end, we compiled a comprehensive data set on state personal income tax rates, corporate income tax rates, $R \& D$ tax credits, and investment tax credits.

Star scientists are important for at least two reasons. First, star scientists are well educated, highly productive workers with high income levels. By studying them, we hope to shed some light on the locational decisions of other well-educated, productive and high income workers. Second, and more fundamentally, star scientists are an important group of workers because their locational decisions have potentially large consequences for local job creation. Unlike professional athletes, movie stars and rich elderly people - the focus of some previous research - the presence of star scientists in a state is typically associated with research and production facilities and in some cases, with the fostering of new industries, from biotech to software to nano-tech. ${ }^{3}$

\footnotetext{
3 The literature has highlighted the role that stars scientists have historically played in the birth and localization of new R\&D-intensive industries. For example, the initial location of star scientists played a key role in determining the localization of the three main biotech clusters in the US (Zucker, Darby and Brewer, 1998). Similar patterns have been documented for semiconductors, computer science and nano-tech (Zucker and Darby, 2006).
} 
Of course, taxes are not the only factor that can determine the location of star scientists. Indeed, we find a limited cross-sectional relationship between state taxes and number of star scientists in a state as the effect is swamped by all the other differences across states. California, for example, has relatively high taxes throughout our sample period, but it is also attractive to scientists because the historical presence of innovation clusters like Silicon Valley and the San Diego biotech cluster.

Our models estimate the elasticity of migration to taxes by relating changes in number of scientists who move from one state to another to changes in the tax differential between the two states. By focusing on changes over time, within a given state pair, our models absorb all timeinvariant factors that can shift the demand and supply of scientists across states.

We uncover large, stable, and precisely estimated effects of personal and business taxes on star scientists' migration patterns. The probability of moving from state $o$ (origin) to state $d$ (destination) increases when the net-of-tax rate (hence after-tax income) in d increases relative to $o$. For the average tax rate faced by an individual at the $99^{\text {th }}$ percentile of the national income distribution, we find a long-run elasticity of about 1.8: a 1\% increase in after-tax income in state $d$ relative to state $o$ is associated with a 1.8 percent long-run increase in the net flow of star scientists moving from $o$ to $d$. The elasticity of the stock of scientists in a given state to a change in that state's ATR is, of course, lower given that the base is larger. To be clear: The flow elasticity implies that if after tax income in a state increases by one percent due to a personal income tax cut, the stock of scientists in the state experiences a percentage increase of 0.4 percent per year until relative taxes change again.

As an illustration, our estimates imply that the effect of New York cutting its statutory personal income tax rate on the top $1 \%$ of earners from $7.5 \%$ to $6.85 \%$ in 2006 was to increase the net inflow of star scientists to the state by about 3 per year, which is a sizable effect over time. Over a ten year period, for instance, this implies an addition of 30 to New York's stock of star scientists - a $2.6 \%$ increase.

We find a similar elasticity for state corporate income tax as well as the investment tax credit (in the opposite direction), while the elasticity for the R\&D credit rate is smaller and statistically insignificant in some specifications. In all, our estimates suggest that both the supply of, and the demand for, star scientists are highly sensitive to state taxes. 
These estimates capture the long run effect of taxes on mobility. When we look at the dynamics of the effects, we find that the effect is smaller in the year after a tax change, and tends to grow over time, presumably because it takes time for firms and workers to relocate. ${ }^{4}$

We can't completely rule out the possibility that our estimates are biased by the presence of unobserved shocks to demand or supply of scientists, but the weight of the available evidence lends credibility to our estimates. First, we find no evidence of pre-trends: Changes in mobility follow changes in taxes and do not to precede them.

Second, we find no evidence that changes in state taxes are correlated with changes in the fortunes of local firms in the innovation sector in the years leading up to the tax change, suggesting that states do not strategically change taxes to help local patenters at times when they are struggling (or thriving). In particular, when we regress changes in state taxes on lagged changes in the market value of the top five patenting companies in the state, we find no relationship.

It is still possible that there are changes in other state policies that could be correlated with taxes. For example, a pro-business state legislature could both cut taxes and relax state level regulations on labor and the environment. It is also possible that states tend to raise personal income taxes during local recessions, and that mobility may be affected by the recession. Our estimated elasticities, however, don't change when we control non-parametrically for time varying shocks to the origin state or destination state. These models fully absorb differences in local business cycles and differences in time-varying policies across origin or destination state. ${ }^{5}$

We present a number of specification tests to further probe the validity of our estimates.

First, corporate taxes should have a larger effect on the demand for private sector scientists than the demand for academic or government scientists. We find that the effect of changes in corporate income taxes is concentrated among private sector inventors. We uncover no effect on academic

\footnotetext{
${ }^{4}$ In interpreting the estimates, two additional points need to be highlighted. First, our estimated elasticities are reducedform parameters reflecting the underlying elasticities of labor demand and labor supply. Changes in personal (corporate) income taxes shift the supply (demand) of scientists to a specific state and therefore involve a movement along the labor demand (supply) curve. For example, if labor demand is inelastic, the change in number of scientist will be small - not because taxes don't matter, but because with fixed demand the only effect of the policy change is higher wages. A second point to keep in mind is that variation in taxes may be associated with variation in public services and local public goods. Our estimates need to be interpreted as measuring the effect of taxes on scientist mobility after allowing for endogenous changes in the supply of public services.

${ }^{5}$ The fact that the local business cycle is not an important issue is not too surprising, given that the overwhelming majority of star scientists work in the traded sector, so that changes to their labor demand reflects national and global shocks, rather than local shocks.
} 
and government researchers. ${ }^{6}$ In addition, while individual inventors are not subject to corporate taxes, they can typically take advantage of R\&D credits. Empirically, we find that individual inventors are not sensitive to corporate taxes but they are sensitive to $R \& D$ tax credits.

Second, and most importantly, corporate taxes should only matter in states where a firm's wage bill has a positive weight in the state's statutory formula for apportioning multi-state income. Empirically, corporate taxes have no effect on the migration flow of stars in states that apportion a corporation's income based only on sales, in which case how much labor the corporation employs in the state has no effect on its tax bill.

Third, we conduct a firm-level analysis in which we focus on firms with research operations in multiple states, like GE or Microsoft. We estimate within firm models to test whether a given firm changes its share of scientists in each state when relative state taxes change - a potentially important channel that could explain part of the overall effect of taxes uncovered above. We find that taxes do indeed affect firms' geographical allocation of scientists. A ten percent increase in a state's corporate income net-of-tax rate results in an increase in the average firm's share of star scientists in that state of 0.7 percentage points. Investment tax credits and R\&D credits have similar effects, while the personal ATR has no effect. Combined with our earlier findings, this implies that within firm geographical reallocation is an important channel explaining the overall effect of business taxes on state employment, although it does not explain the effect of personal taxes.

Overall, we conclude that state taxes have a significant effect of the geographical location of star scientists. While there are many other factors that determine where innovative individuals and innovative companies decide to locate, there are enough firms and workers on the margin that relative taxes matter. This cost of higher state tax rates should be taken into consideration by local policymakers when deciding whom to tax and how much to tax.

Our paper is part of a small group of papers on the sensitivity of employment to local taxes. Existing studies for the U.S. uncover generally mixed results. Cohen, Lai, and Steindel (2011) find mixed evidence of tax-induced migration of the general population. Young and Varner (2011) and Varner and Young (2012) find no evidence of tax-induced migration in the case of "millionaires taxes” in California and New Jersey. Serrato and Zidar (2014) focus on corporate taxes and find

\footnotetext{
${ }^{6}$ Interestingly, while mobility of corporate scientists is sensitive to changes in personal taxes, mobility of academic scientists is not, possibly reflecting the fact that academic scientists are not entirely driven by pecuniary motives and that their mobility decisions depend on presence of colleagues, academic prestige, and other non-monetary factors.
} 
moderate effects on wages, total employment and land prices. Giroud and Rauh (2015) find an effect of business taxes on the number of establishments and establishment size. Bakija and Slemrod (2004) find a moderate effect of state personal income tax on the number of federal estate tax returns. There is also a small, related literature on taxes and international mobility. The paper closest to ours is contemporaneous work by Akcigit et al. (2015), who, like us, focus on scientists and find lower elasticities of the number of domestic and foreign inventors with respect to the personal income tax rate. Kleven, Landais, and Saez (2013) focus on European soccer players, while Kleven, et al. (2014) study a specific tax change in Denmark and find elasticities similar to ours. ${ }^{7}$

\section{Data and Basic Facts}

\subsection{Scientists}

We use a unique dataset obtained by combining data on top scientists to data on state taxes. Specifically, to identify the location of top scientists, we use the COMETS patent database (Zucker, Darby, \& Fong, 2011). Each patent lists all inventors on that patent as well as their address of residence. Exact addresses are frequently not reported, but state of residence nearly always is. We define "star" inventors, in a given year, as those that are at or above the $95^{\text {th }}$ percentile in number of patents over the past ten years. In other words, stars are exceptionally prolific patenters. The $95^{\text {th }}$ cutoff is arbitrary, but our empirical results are not sensitive to it. In some models we use star measures where patents are weighted by number of citations and obtain similar results. ${ }^{8}$

One advantage of our data is that our information on geographical location is likely to reflect the state where a scientist actually lives and works (as opposed to tax avoidance). Patenters must report their home address on their patent application and have no economic incentive to misreport it. There is no legal link between where a patent's inventor(s) live and the taxation of any income generated by the patent for the patent assignee/owner. ${ }^{9}$

\footnotetext{
${ }^{7}$ See also Kirchgassner and Pommerehne (1996), Schmidheiny (2006), and Liebig, Puhani and Sousa-Poza (2007).

${ }^{8}$ If a patent has multiple inventors, we assign fractions of the patent to each of its inventors. For example, if a patent has four inventors, each inventor gets credited with one-quarter of a patent.

${ }^{9}$ In our analysis we use patents simply to locate the taxpayers, irrespective of where the R\&D activity takes place. Consider a computer scientist who patents software. It is conceivable that one year he may apply for a patent while living in CA, then the next year apply for a patent in Texas, the year of a tax increase in CA. The fact that he may have been working on the technology he patented in Texas while living in CA seems irrelevant. Separately, we note that a small but growing share of patents is made of defensive patents. To the extent such patenting yields some misidentification of "stars", this causes measurement error in the dependent variable and should reduce the precision
} 
The sample of inventors consists of roughly 260,000 star-scientist*year observations over the period from 1977 to 2010. Year is defined as year of the patent application, not the year when the patent is granted. For each scientist observed in 2 consecutive years, we identify their state of residence in year $t$, which we call their "origin" state, and their state of residence in year $t+1$, which we call their "destination" state. ${ }^{10}$ For each origin-destination pair of states (including those where the origin and destination are the same) and year in our sample, we then compute the number of star scientists moving from origin state to destination state. From this we form our primary outcome of interest, the probability of a star scientist moving from a given origin state to a given destination state relative to the probability of not moving at all. This measure is known as the outmigration odds-ratio.

Not every star scientist applies for a patent every year, so we don't observe the location of every star in every year. We are therefore likely to underestimate the overall amount of geographical mobility of star scientists, as our data miss the moves that occur between patent applications. This problem is unlikely to be quantitatively very large. Our population of star scientists is, by construction, comprised of prolific patenters and the typical individual is observed patenting in most years (over the period in which they patent at all). The mean number of patents per star scientist in the decade between 1997 and 2006 is 15.7. Thus, star scientists in our sample patent an average of 1.5 patents per year. The $25^{\text {th }}$ percentile, median and $75^{\text {th }}$ percentiles over the decade are 4, 10 and 19 respectively. As a check, we have tested whether our estimates are sensitive to including all years in between patents, assuming that the scientist location in a year reflects the state where the most recent patent was filed. Our estimates are not sensitive to this change.

While we might underestimate overall mobility, our estimates of the effect of taxes remain valid if the measurement error in the dependent variable is not systematically associated with changes in taxes. Intuitively, we underestimate the amount of mobility in states that change taxes and in states that do not change taxes by the same amount. One concern is the possibility that moving lowers the probability of patenting - either because it is distracting and time consuming or because it coincides with a job spell with a new employer, and the scientist may be restricted from using intellectual property created while working for previous employer. This could lead us to

of our estimates, but not bias our estimates. Moreover, when we alternatively define stars based on citations, which should downweight defensive patents, we find very similar results.

${ }^{10}$ If the inventor has multiple patents with multiple state addresses in a single year, we use the modal state. 
underestimate mobility following tax increases and therefore it could lead us to underestimate the effect of taxes. In practice, we expect this bias to be relatively minor. As we mention, most of our scientists patent very frequently. Moreover, in many fields the timing of patent application and of measured formal R\&D is close, often contemporaneous (Griliches, 1998). One exception, of course, is pharmaceuticals. There is also anecdotal evidence on patents being applied for at a relatively early stage of the R\&D process (see Wes Cohen 2010). A similar bias would occur if taxes are systematically associated with selection in and out of the labor force. For example, if high state taxes induce some star scientists to exit the labor force and stop patenting, we underestimate the true effect.

Appendix Figure 2 shows where top scientists were located in 2006. Appendix Table A1 shows these levels along with their changes over the sample period. Star scientists are a mobile group: Not unlike top academic economists, they face a national labor market and intense competition among employers. Indeed, the vast majority of star scientists either work in the private sector (90\%) or academia (4\%), with the remainder working in government, other nonprofit institutions, or for themselves.

Despite the labs and fixed capital associated with some fields, star scientists on the whole manage to have high rates of cross-state mobility. In particular, the gross state-to-state migration rate for star scientists was 6.5\% in 2006. By comparison, the rates in the entire US adult population and the population of individuals with professional/graduate degree were $1.7 \%$ and $2.3 \%$, respectively (Kaplan \& Schulhofer-Wohl 2013). Overall, 6\% of stars move at least once; the average moves per star is 0.33 ; and the average moves per star, conditional on moving at least once, is 2.6 .

In Table 1, we show the bilateral outflows among the ten largest states in terms of population of star scientists on average over the recent decade, 1997-2006. The state pair with the most bilateral flows over this decade was California-Texas. 26 star scientists per year moved from Texas to California and 25 per year moved from California to Texas. Close behind was CaliforniaMassachusetts, with 25 per year moving from Massachusetts to California and 24 moving in the opposite direction.

The sample that we use in the empirical analysis has the bilateral migration flows for every pair of states (plus District of Columbia) (51x51) for every year from $t=1977$ to 2009 (measuring the number of star scientists that report residing in the origin state in year $t$ and the destination state 
in year $t+1$ ). Out of the potential 84,150 origin*destination*year cells ${ }^{11}$, 15,247 have positive migration flows. Because the log odds-ratio is undefined when the migration flow is zero, 15,247 is the number of observations used in our baseline regressions. We come back to the implications of this point in Section 5.4.

\subsection{State Taxes}

We combine this patenter data with a rich comprehensive panel data set that we compiled on personal and business tax and credit rates at the state-year level. ${ }^{12}$

(A) For personal taxes, we focus on state-level variation in the individual income average tax rate (ATR) faced by a hypothetical taxpayer at the $99^{\text {th }}$ percentile of the national income distribution. We stress that we don’t observe scientist income; we assume that their salary and capital gain income is in the top $1 \%$. Given how productive these scientists are, this assumption is realistic; it is also consistent with confidential IRS data analyzed by Bell et al. (2015). We find generally similar results if we assume an income level at the $99.9 \%$ or $95 \%$ percentiles of the distribution.

ATR is not a statutory rate. Rather, it is the individual income tax liability as a share of gross income for a given taxpayer. For our baseline analysis, we use the ATR - rather than statutory marginal tax rates - because workers deciding on where to locate should in principle focus on average tax rates, not marginal tax rates. In practice, the ATR is monotonically increasing in the MTR and the two are highly correlated. For star scientists, this correlation is even higher: because stars scientists are highly paid, their average rate is well approximated by the top marginal rate in many states. Empirically, our results based on ATR and MTR are generally similar. (We report estimates based on the MTR in the Appendix)

We use total ATR, inclusive of both federal and state taxes. The reason for using total ATR instead of just the component due solely to state income tax (i.e., the individual's state tax liability divided by their income) is to account for interactions between state and federal tax rates. While the vast majority of the geographical variation in ATR is driven by differences in statutory tax rates across states, states also vary in how they treat federal taxes. In some states, federal taxes can be

\footnotetext{
11 Total number of potential origin*destination*year cells, excluding cells where origin $=$ destination, is [(51*51) $51]^{*}(2009-1977)=84,150$.

${ }^{12}$ From the NBER's TaxSim calculator, we obtained both marginal and average individual income tax rates by state and year for a hypothetical scientist whose salary and capital gains income are at a specific national income percentile for that year $\left(50^{\text {th }}, 95^{\text {th }}, 99^{\text {th }}\right.$, or $99.9^{\text {th }}$ percentile). The national income percentiles are obtained from the World Top Incomes Database (Alvaredo, Atkinson, Piketty \& Saez 2013). We obtain statutory rates by state and year for corporate income taxes, investment tax credits, and research and development tax credits from Chirinko \& Wilson (2008), Wilson (2009), and Moretti \& Wilson (2014). See the Online Data Appendix for more details.
} 
deducted from state taxes, while in other states they cannot. In addition, state individual income taxes can affect whether someone is subject to the federal alternative minimum tax. Our ATR measure takes into account the interactions between state and federal tax rates, as well as other complicated features of state and federal personal income taxes. See the Online Data Appendix for more details.

For some specifications, we also use data on state sales tax rates from Fajgelbaum, et al. (2015) and on property taxes as a share of state income from the U.S. Census Bureau's Survey of State and Local Government Finances.

(B) For business taxes, we focus our analysis primarily on the corporate tax rate, which is the primary business tax faced by corporations at the state level. Since states generally have only a single corporate income tax rate, marginal and average rates are the same. We also consider the effects of the investment tax credit rate and the $R \& D$ tax credit rate, as most states offer one or both of these credits. The investment tax credit typically is a credit against corporate income tax proportional to the value of capital expenditures the company puts in place in that state. Similarly, an R\&D tax credit is proportional to the amount of research and development spending done in that state. In many states, the $R \& D$ credit is available both to corporations (against corporate income tax) and non-corporations (against individual income tax).

Figure 3 and Appendix Figure 1 show how top individual income tax rates and CIT rates have evolved over time. Two points emerge. First, changes in taxes do not appear very systematic. We see examples of blue states with high taxes lowering their rates, and examples of red states with low taxes raising their rates. Second, while in the cross-section personal taxes and business taxes are positively correlated, changes over time in personal taxes and business taxes are either not correlated or slightly negatively correlated. For example, Appendix Figure 3 shows a scatter plot of the five-year change in the CIT against the five-year change in the $99^{\text {th }}$ percentile ATR for the five-year intervals from 1980 to 2010. The estimated slope of this relationship is far from one, at 0.064. The correlations between changes in $99^{\text {th }}$ percentile ATR's and changes in ITC or R\&D are also slightly negative. This suggests that any source of endogeneity applying to one of these tax policies is unlikely to apply to the other.

It is important to clarify exactly why corporate taxes might be expected to affect employer location decisions. As we note above, state taxation of income generated by patents (e.g., royalties) is independent of where the patents' inventors reside. For instance, suppose a patent's inventors 
live in California and work for a multistate corporation, the patent owner. California has no more claim to taxing the corporate income generated by that patent than any other state in which the corporation operates. The patent income becomes part of the corporate taxpayer's national business income, which is apportioned to states based on each state's apportionment formula (described below). Hence, to the extent that labor demand for star scientists in a state is affected by that state's corporate tax rate, it is because star scientists and the associated R\&D operations account for part of the company's payroll in that state, not because the patenting income is disproportionately taxed by that state.

Each state has an apportionment formula to determine what share of a corporation's national taxable business income is to be apportioned to the state. Prior to the 1970s, virtually all states had the same formula: the share of a company's income in the state was determined by an equalweighted average of the state's shares of the company's national payroll, property, and sales. Over the past few decades, many states have increased the weight on sales in this formula as a means of incentivizing firms to locate property and payroll in their state. Today, many states have a salesonly apportionment formula. In such states, a corporate taxpayer's tax liability is independent of the level of employment or payroll in the state. Therefore, the effect of changes in corporate tax rates should be small in states with a sales-only formula - a hypothesis we test in Section 5.5. ${ }^{13}$

Note that what matters for an employer is not just the part of the company's payroll associated with a given star scientist, or set of star scientists, directly. Even more relevant is the part of the payroll associated with the entire R\&D operation (lab, research center, etc.) tied to them. In most cases, payroll for the entire R\&D activity is much larger than the scientist payroll. In other words, a scientist location affects corporate taxes not simply because her salary directly affects the amount of corporate income taxes in that location, but because the presence of all the other R\&D personnel affects the amount of corporate income taxes in that location (through the payroll factor in formulary apportionment of income).

\section{Framework and Econometric Specification}

\footnotetext{
${ }^{13}$ Even for states with zero apportionment weight on payroll we expect some sensitivity to the corporate tax rate because of single-state corporations and the potential effect of corporate taxes on new business start-ups. In most states, R\&D tax credits can be claimed on either corporate or individual income tax forms (but not both), so they could potentially affect locational outcomes of all scientists, not just those working for corporations. Investment tax credits (ITCs), on the other hand, generally can only be taken against corporate income taxes. ITCs and the corporate income tax itself, of course, we would expect to affect only locational outcomes of scientists working for corporations. We test this hypothesis below.
} 
In this section, we present a simple model of scientist and firm location designed to guide our empirical analysis. We use the model to derive our econometric specification.

\subsection{Location of Scientists and Firms}

We model personal income taxes as shifters of the supply of scientist labor supply to a state: higher taxes lower labor supply to a state, all else equal. We model business taxes and credits as shifters of the demand for scientists in a state: higher taxes lower the labor demand for scientists in a state, all else equal.

Scientist Location. In each period, scientists choose the state that maximizes their utility. The utility of a scientist in a given state depends on local after-tax earnings, cost of living, local amenities, and the worker's idiosyncratic preferences for the state. Mobility is costly, and for each pair of states $o$ (origin) and $d$ (destination), the utility of individual $i$ who lived in state $o$ in the previous year and moves to state $d$ at time $t$ is

$$
U_{\text {iodt }}=\alpha \log \left(1-\tau_{d t}\right)+\alpha \log w_{d t}+Z_{d}+e_{\text {iodt }}-C_{o d}
$$

where $w_{d t}$ is the wage in the current state of residence before taxes; $\tau_{d t}$ is personal income taxes in the state of residence; $\alpha$ is the marginal utility of income; $Z_{d}$ captures amenities specific to the state of residence and cost of living; $e_{\text {iodt }}$ represents time-varying idiosyncratic preferences for location, and measures how much worker $i$ likes state $d$ net of the after-tax wage, amenities and cost of living; and $C_{o d}$ is the utility cost of moving from $o$ to $d$, which does not need to be symmetric and is assumed to be 0 for stayers $\left(C_{o o}=0\right){ }^{14}$

The utility gain (or loss) experienced by scientist $i$ if she moves from state $o$ to state $d$ in year $t$ is a function on the difference in taxes, wages, amenities and any other factors that affect the utility of living in the two states, as well as moving costs:

$$
U_{\text {iodt }}-U_{\text {ioot }}=\alpha\left[\log \left(1-\tau_{d t}\right)-\log \left(1-\tau_{o t}\right)\right]+\alpha\left[\log \left(w_{d t} / w_{o t}\right)\right]+\left[Z_{d}-Z_{o}\right]-C_{o d}+\left[e_{\text {iodt }}-e_{\text {ioot }}\right]
$$

Individual $i$ currently living in state $o$ chooses to move to state $d$ if and only if the utility in $d$ net of the cost of moving is larger than the utility in $o$ and larger than the utility in all other 48

\footnotetext{
${ }^{14}$ Our models is kept deliberately simple, and ignores some important determinants of utility. For example, we assume that each scientist works and ignore labor supply reactions. We also ignore utility from non-pecuniary aspects of the job; and we ignore any household considerations. As it will become clear below, these simplifying assumptions do not affect our estimation strategy or the interpretation of our estimates.
} 
states: $U_{\text {iodt }}>\max \left(U_{\text {iod' }} t\right)$ for each $d \neq d$ Thus, in this model, scientists move for systematic reasons

(after-tax wage and amenities) and idiosyncratic reasons. A realistic feature of this setting is that it generates migration in every period, even when taxes, wages and amenities don't change. This idiosyncratic migration is driven by the realization of the random variable $e_{\text {iodt }}$. Intuitively, workers experience shocks that affect individual locational decisions over and above after tax-wages and amenities. Examples of these shocks could include family shocks or taste shocks.

Consider the case of an unexpected and permanent change in taxes occurring between $t-1$ and $t$. We are interested in how the change in taxes affects the probability that a scientist chooses to relocate from state $o$ to $d$. The magnitude of the effect of a tax increase depends on how many marginal scientists are in that state, and therefore on the distribution of the term $e$. If $e_{\text {iodt }}$ follows an i.i.d. Extreme Value Type I distribution (McFadden, 1978), the log odds ratio is linear in the difference in utility levels in the origin and destination state:

$$
\log \left(P_{\text {odt }} / P_{\text {oot }}\right)=\alpha\left[\log \left(1-\tau_{d t}\right)-\log \left(1-\tau_{o t}\right)\right]+\alpha\left[\log \left(w_{d t} / w_{o t}\right)\right]+\left[Z_{d}-Z_{o}\right]-C_{o d}
$$

where $P_{\text {odt }} / P_{\text {oot }}$ is the scientist population share that moves from one state to another $\left(P_{\text {odt }}\right)$ relative to the population share that does not move $\left(P_{o o t}\right)$.

This equation can be interpreted as the labor supply of scientists to state $d$. Intuitively, in each moment in time, residents of a state have a distribution of preferences: while some have strong idiosyncratic preferences for the state (large $e$ ), others have weak idiosyncratic preferences for the state (small $e$ ). A tax increase in the origin state induces residents with marginal attachment to move away. Similarly, a tax decrease in a potential destination state induces residents in other states that have marginal attachment to those states to move to the destination state. By contrast, inframarginal residents - those with stronger preferences for the origin state - don't move: they optimally decide to stay and to take a utility loss. Of course, both movers and stayers are made worse off by the tax. The marginal movers are made worse off because they need to pay the moving costs. The inframarginal stayers are made worse off because the tax reduces some of the rent that they derive from the state.

Our setting differs from the standard random utility model of location choice where individuals decide every period where to locate, irrespective of where they were last period. By contrast, in our model the utility of being in any location at time $t+1$ is always conditional on the 
state of origin in year $t$. We consider this assumption plausible, because it implies that the cost of moving is not a constant, but can be different for different pairs of states. Moving from, say, California to Massachusetts probably involves different costs than moving from Rhode Island to Massachusetts. ${ }^{15}$

An implication of this assumption is the existence of non-random permanent migration flows across states that do not come from changes in relative wages or amenities. This prediction is consistent with the evidence. Data on star scientist migration show long run differences in outflows across states. By contrast, in the standard model, individuals do move across states in equilibrium, but these movements are random because they are only driven by the realization of the idiosyncratic component of utility $e_{\text {odt }}$.

Firm Location. The location of star scientists is not only a reflection of where scientists would like to live, but also where firms who employ scientists decide to locate. Hence, migration flows may well be sensitive not only to the individual income tax rates faced by star scientists, but also to the business tax rates faced by employers.

In each period, firms choose the state that maximizes their profits. ${ }^{16}$ Assume that firm $j$ located in state $d$ uses one star scientist and the state productive amenities to produce a nationally traded output $Y$ with price equal to 1:

$$
Y_{j d t}=f\left(Z^{\prime}, v_{j d t}\right)
$$

where $Z^{\prime}{ }_{d}$ represents productive amenities available in state $d$. In each potential state and year, a firm enjoys a time-varying productivity draw $v_{j d t}$ that captures the idiosyncratic productivity match between a firm and a state. Some firms are more productive in a state because of agglomeration economies, location of clients, infrastructure, local legislation, etc. For instance, in the presence of agglomeration economies, the existence of a biotech cluster in a state might increase the productivity of biotech firms in that state but have no effect on the productivity of software firms. The term $v_{j d t}$ is important because it allows firm owners to make economic profits in equilibrium, so that the elasticity of location choice with respect to taxes is not infinite (Serrato and Zidar, 2014). It is possible to generalize this technology to include other types of labor and capital.

\footnotetext{
${ }^{15}$ We do not constrain these costs to be symmetric.

${ }^{16}$ We use the term "firm" here for exposition, but the model would also apply to a unit within a multi-state firm.
} 
If a firm relocates to state $d$, its profits are equal to revenues net of labor costs and corporate taxes in $d$ and net of moving costs to $d$. Assume in particular that the profits of a firm that relocates from state $o$ to state $d$ can be approximated as

$$
\log \pi_{j o d t}=Z^{\prime}{ }_{d}+v_{\text {iodt }}-\log w_{d t}+\beta \log \left(1-\tau_{d t}{ }_{d t}\right)-C^{\prime}{ }_{\text {od }} .
$$

where $\tau^{\prime}{ }_{d t}$ is the corporate income tax rate; and $C^{\prime}{ }_{o d}$ is the cost for firms of moving from $o$ to $d$, assumed to be 0 for stayers and potentially different from the cost faced by individuals. Firm $j$ moves to state $d$ if and only if $\pi_{\text {iodt }}>\max \left(\pi_{\text {iod }} t\right)$ for each $d \neq d^{\prime}$. If $v_{\text {iodt }}$ follows a iid Extreme Value Type I distribution, the log odds ratio takes the form

$\log \left(P^{\prime}{ }_{\text {odt }} / P^{\prime}{ }_{\text {oot }}\right)=\beta\left[\log \left(1-\tau^{\prime}{ }_{d t}\right)-\log \left(1-\tau^{\prime}{ }_{o t}\right)\right]-\left[\log \left(w_{d t} / w_{o t}\right)\right]+\left[Z^{\prime}{ }_{d}-Z^{\prime}{ }_{o}\right]-C^{\prime}{ }_{o d}$

where $\left(P{ }^{\prime}{ }_{\text {odt }} / P{ }^{\prime}{ }_{o o t}\right)$ is the population share of firms starting in $o$ that move to $d$ between $t$ and $t+1$, divided by the population share of firms initially in state $o$ that do not move. Since each firm employs one star scientist, this equation can be interpreted as the labor demand for scientists in state $d$.

In our setting, taxes and credits matter for individual and firm location choice, although the elasticity is not necessarily infinite as it would be in the case of homogenous individuals and firms (Moretti 2011, Serrato and Zidar 2014).

\subsection{Econometric Model}

Equation (1) expresses the probability that a star scientist relocates from state $o$ to state $d$ as a function of the wage difference between $o$ and $d$ and the personal tax difference. Equation (2) expresses the probability that a firm employing a star scientist relocates from state $o$ to state $d$ as a function of the wage difference between $o$ and $d$ and the corporate tax difference. In equilibrium, labor demand needs to equal labor supply in each state and year. Equating $\log \left(P_{\text {odt }} / P_{\text {oot }}\right)$ in (1) to $\log \left(P{ }^{\prime}{ }_{\text {odt }} / P^{\prime}{ }^{\prime}{ }_{\text {ot }}\right)$ in (2) yields an expression for the equilibrium number of scientists who move as a function of tax differentials:

$$
\log \left(P_{\text {odt }} / P_{\text {oot }}\right)=\eta\left[\log \left(1-\tau_{d t}\right)-\log \left(1-\tau_{o t}\right)\right]+\eta^{\prime}\left[\log \left(1-\tau_{d t}^{\prime}\right)-\log \left(1-\tau^{\prime}{ }_{o t}\right)\right]+\gamma_{d}+\gamma_{o}+\gamma_{o d}+u_{o d t}
$$

where $\eta=\alpha /(1+\alpha)$ is the effect of personal taxes; $\eta^{\prime}=\beta \alpha /(1+\alpha)$ is the effect of corporate taxes; $\gamma_{d}=[\alpha /(1+\alpha)]\left[Z_{d}+Z_{d}^{\prime}\right]$ is a vector of state fixed effects that captures both consumption and production amenities in the state of origin; $\gamma_{o}=[\alpha /(1+\alpha)]\left[Z_{o}+Z_{o}^{\prime}\right]$ is a vector of state fixed effects that captures both consumption and production amenities in the state of destination; and $\gamma_{\text {od }}=-\left(C_{o d}\right.$ 
$\left.+C^{\prime}{ }_{o d}\right)$ is a vector of state-pair fixed effects that captures the cost of moving for individuals and firms for each state pair; and we have added an error term $u_{\text {odt. }}$

Equation (3) represents our baseline econometric specification, although in some models, we include additional controls. (To control for time-varying regional shocks, we augment equation (3) by including region-pair*year effects. To control for time-varying state specific shocks, in some models we augment it by including state-of-origin*year effects or state-of-destination*year effects.)

In interpreting our estimates of the parameters $\eta$ and $\eta$ ', three important points need to be considered. First, the parameters $\eta$ and $\eta$ ' are the reduced form effect of taxes on employment. As such, their magnitude depends on labor demand and supply elasticities, which in turn are a function of $\beta$ and $\alpha$. Changes in personal income taxes shift the supply of scientists to a specific state and therefore involve a movement along the labor demand curve. The ultimate impact on the equilibrium number of scientists depends on the slope of labor demand curve. If labor demand is highly elastic, the change in scientists will be large. If demand is inelastic, the change in number of scientist will be small - not because taxes don't matter, but because with fixed demand the only effect of the policy change is higher wages.

Similarly, changes in business taxes affect the demand of scientists in a given state and therefore involve a movement along the supply curve. The ultimate impact on the equilibrium number of scientists depends on the slope of labor supply curve. For a given shift in demand, the change in number of scientists will be larger the more elastic is labor supply. Empirically, we expect labor demand faced by a state to be elastic in the long run. Since in the long run firms can locate in many states, local labor demand is likely to be significantly more elastic than labor demand at the national level.

Although our estimates of $\eta$ and $\eta$ ' are reduced form estimates, they are the parameters of interest for policy makers interested in quantifying employment losses that higher taxes might cause. $^{17}$

A second point to consider is that our empirical models capture the long run effect of taxes. The long run effects are likely to be larger than the immediate effect, because it takes time for people and firms to move. In addition, some of the tax changes are temporary. Permanent tax changes are

\footnotetext{
17 Scientists often receive complicated compensation contracts. It's in principle possible that the importance of forms of non-monetary compensation change in reaction to changes in state taxes. This affects the way our estimates are to be interpreted, not their validity because our models capture the reduced form effect of taxes including any offsetting effect that might come from the endogenous adjustment of contracts.
} 
likely to have stronger effects than temporary changes. Moreover, our models measure not only the direct effect of taxes, but also any indirect effect operating through agglomeration economies, if they exist. For example, consider the case where a tax cut results in an increases in the number of biotech scientists in a state; and such exogenous increases makes that state endogenously more attractive to other biotech scientists. Our estimates will reflect both the direct (exogenous) effect and the indirect (endogenous) agglomeration effect.

A third point to keep in mind in interpreting our estimates is that variation in taxes may be associated with variation in public services and local public goods. Our estimates need to be interpreted as measuring the effect of taxes on scientist mobility after allowing for endogenous changes in the supply of public services. If higher taxes translate into better public services, our estimates are a lower bound of the effect of taxes holding constant the amount of public services. Consider for example the case where a state raises taxes in order to improve schools, parks and safety. If star scientists and their families value these services, the disincentive effect of higher taxes will be offset to some extent by the improved amenities. In the extreme case where the value of the new public services is equal to the tax increase, the disincentive effect disappears.

In general, however, the cost of taxation to high income taxpayers is unlikely to be identical to the benefits of public services enjoyed by high-income individuals. First, a significant part of state taxation is progressive and redistributive in nature. High income individuals tend to pay higher tax rates and receive less redistribution than low income individuals. Second, it is realistic to assume that high income individuals are likely to consume less public services than low income individuals. For example, high income individuals are more likely to send their children to private schools than low income individuals. Finally, due to deadweight loss of taxation, and overall inefficiency of the public sector, the disincentive effect will still exist, but it will be lower than the pure monetary value of the tax increase.

With estimates of the parameters $\eta$ and $\eta$ ', it is straightforward to calculate the average elasticity of the probability of moving with respect to the net-of-tax rate. For example, for personal taxes the elasticity is

$$
e=E\left[\frac{d \log P_{o d t}}{d \log \left(1-\tau_{o t}\right)}\right]=\eta(1-P)
$$


where $P$ is the weighted average of $P_{o d t}$ over all $(d, o, t)$ observations, weighting each combination by the number of individuals in that observation cell. In our sample, $P=0.06$, so the elasticities will be very close to $\eta$.

\subsection{Inference}

In estimating standard errors, we face two issues that need to be accounted for.

(i) First, errors might be correlated, within a given year, across pair*year observations sharing the same origin state because the origin tax rates are constant across the 51 observations involving that origin state in that year. Likewise, errors could be correlated across observations within a given year that share the same destination state. This gives rise the classic clustering concern addressed in Moulton (1990).

(ii) Second, errors might be correlated over time within the panel dimension (Bertrand, Duflo and Mullainathan, 2004).

Throughout the paper, we show standard errors that are robust to heteroskedasticity and allow for three-way clustering by origin*year, destination*year and origin-destination pair. Our threeway clustering deals with the first problem because it has clustering by origin-state*year and destination-state*year. It deals with the second problem by allowing unrestricted serial correlation over time within each origin-destination pair, which is the cross-sectional unit in our panel. To be clear: it rules out correlation in the residual between an origin-destination pair in year $t$ and a different pair in a different year.

Formally, if edt is the residual for origin state $o$, destination state $d$ in year $t$, we allow for unrestricted serial correlation within the $o-d$ pair: $\operatorname{corr}\left(\mathrm{e}_{\text {odt }}, \mathrm{e}_{\text {odt }+\mathrm{k}}\right)$ can be $\neq 0$, for any $k$; but we assume that $\operatorname{corr}\left(\mathrm{e}_{\mathrm{odt}}, \mathrm{e}_{\mathrm{pqt}}+\mathrm{k}\right)=0$ if $p \neq o$ or $q \neq d$. In words, we require that the unobserved determinants of migration flows between a pair of states in a given year are uncorrelated with unobserved determinants of migration flows between a different pair of states in a different year. For example, take CA, TX, MA and WA. We allow for the residual for the CA-TX pair in year $t$ to be correlated with the residual in any other year, however distant. But we assume that the residual for the CATX pair in year $t$ is uncorrelated with the residual for the MA-WA pair in a different year. Keep in mind that our preferred specification conditions on pair fixed effects and region-pair*year effects.

Empirically, this assumption seems consistent with the data. We tested for and rejected firstorder autocorrelation between the residual for a given origin-destination pair in year $t$ and the 
residual for each other pair in year $t-1$ (even if they share a common origin state or a common destination state.) A regression of the former residual on the latter residual yielded a statistically insignificant coefficient of -0.002 (p-value - 0.649).

We also present standard errors based on an alternative estimator proposed by Driscoll and Kraay (1998). Recall that our 3-way clustering approach allows for general correlation of errors across time within a state pair. The Driscoll-Kraay of the variance-covariance (VC) matrix estimator addresses the concern that there could be correlation over time between observations for different pairs. In our context, this could occur because different pairs could share the same origin state or share the same destination state. The Driscoll-Kraay VC estimator generalizes the standard panel Newey-West VC estimator to additionally allow for cross-sectional dependence in the error term. ${ }^{18}$ This approach allows cross-sectional correlation not only within the same time period but also across time periods up to an assumed maximum autocorrelation lag.

In our context, Driscoll-Kraay assumptions on cross-sectional correlation are more general than 3-way clustering because they allow for correlation between two pairs sharing the same origin (or destination) not only within the same year but also across years up to the assumed maximum lag. However, the Driscoll-Kraay assumptions on within-pair serial correlation are less general because 3-way clustering makes no assumptions on the structure or length of serial correlation. Despite relying on a different set of assumptions, 3-way clustering and Driscoll and Kraay yield estimated standard errors that are remarkably similar.

\section{Identification, Threats to Validity and Non-Random Selection}

\section{(A) Omitted variables.}

Taxes are set by state legislatures, certainly not in random ways. The key concern is that there are omitted determinants of scientist migration decisions that may be correlated with changes in personal or corporate taxes.

Our identification relies on the assumption that, absent tax changes, differences in migration flows of scientists across pairs of states are fixed over time (after controlling for regional shocks)

\footnotetext{
${ }^{18}$ The resulting standard errors are robust to "heteroskedasticity, serial correlation, and spatial correlation" (Vogelsang 2012). The only requirement for consistency is that the time dimension ( $T$ ) is "large" (which is also required for consistency of the cluster-robust estimator) and that the data are covariance stationary in the time dimension (the same requirement of the standard Newey-West estimator), which essentially means that autocorrelation decays with lag length. Vogelsang develops asymptotically valid Driscoll and Kraay standard errors and p-values for the case of panel and time fixed effects. We use Vogelsang's stata code.
} 
or, if they vary, they vary for reasons that are not correlated with tax changes. A plausible alternative assumption would be that, absent tax changes, differences in stocks of scientists across states are fixed over time (after controlling for regional shocks) or, if they vary, they vary for reasons that are not correlated with tax changes. We consider our identifying assumption more likely to be valid because it relies on weaker assumptions. By estimating how bilateral flows react to changes in origin-destination tax differentials, we are differencing out all the permanent factors that might affect stocks of scientists and might be possibly correlated with tax changes.

Put differently, our models control for permanent heterogeneity in migration flows, not just at the state level, but at the state pair level. Thus, we account not only for the fact that in our sample period some states tend to lose scientists and other states tend to gain scientists, but also for the typical migration flow between every pair of states during our period. For example, if star scientists tend to move to California from mid-western states because they value local amenities like weather or because California has historically important clusters of innovation-driven industries (e.g., Silicon Valley), state pair effects will account for these factors, to the extent that they are permanent.

Of course, there may be omitted determinants of changes in migration flows that are correlated with changes in taxes. Consider the business cycle, for example, which in many states is an important determinant of changes in taxes. If states tend to increase personal income taxes during recessions, and scientists tend to leave the state during recessions, then our estimates overestimate the true effect of taxes because they attribute to taxes some of the effect of recessions. ${ }^{19}$ On the other hand, if states are reluctant to impose higher taxes during recessions, when local employers are struggling, then we underestimate the effect of taxes.

The possibility of unobserved labor demand shocks driven by local business cycle is probably not a major issue because the overwhelming majority of star scientists work in the traded sector. Shocks to the demand of star scientists are likely to reflect shocks that are national or global in scope, and unlikely to reflect state specific shocks. For example, Google is based in California, but its customers are all over the country and the world. When demand for search engines and online advertising increases, Google hires more scientists and engineers; and when it declines Goggle hires fewer scientists and engineers. These shocks are unlikely to reflect the state of the California

\footnotetext{
${ }^{19}$ Diamond (2014) for example argues that local governments are more likely to extract rents during good times.
} 
economy relative to other states. Rather, these shocks more likely reflect the general state of the national economy, interest rates, etc. ${ }^{20}$

In practice, our models control for region-of-origin*region-of-destination*year effects. Thus, the regional component of local business cycle is fully absorbed. In some of our models, we even control for state-of-origin*year effects or state-of-destination*year effects. Thus, the state component of local business cycle is partially absorbed. In addition, we show that the estimated effect of taxes on star migration is robust to conditioning on the contemporaneous unemployment rates and the population growth rate in both the origin and destination states.

Another concern is the possibility that state legislatures change tax policies to help local patenters. Our models yield inconsistent estimates if state governments tend to change their tax policies based on criteria that are correlated with unobserved determinants of the economic fortunes of local employers - and in particular if they target local patenters. This may happen, for example, if state governments tend to use tax policy to help local patent-intensive industries that are struggling and are experiencing declines in employment over and above those experienced in other states. A similar concern arises in the opposite scenario, if state governments tend to use tax policy to help employers that are thriving, and experiencing increases employment over and above those experienced in other states. In either case, OLS estimates will be biased. The sign of the bias is $a$ priori undetermined. If states help winners, the correlation between taxes and unobserved labor demand shocks is negative. If states help losers (compensatory policies), the correlation is positive. Note that for this to be a problem it is not enough that states change taxes to help local employers. They also need to specifically target local patenters.

Empirically, changes in taxes do not appear to be systematically associated with the fortunes of local patenters. We identify the top publicly traded patenting companies in each state and then test whether personal and corporate state tax rates in a given year are a function of local patenter stock returns in the same year or in previous years. If states change their taxes to help struggling local patenters, we should observe that tax changes systematically occur when local patenters' stock are under-performing. If states change their taxes to help thriving local patenters, we should observe that tax change systematically occur when local patenters’ stock are under-performing.

We first identify the top five patent assignees (in terms of patent counts over the full 1977-2010 sample) in each state. The majority of these assignees are publicly traded companies; for those, we

\footnotetext{
${ }^{20}$ If anything, the weakness of the local economy may help retain Google scientists because of lower cost of housing.
} 
match by company name to the Compustat financial database. We then calculate the sum of market capitalization over these top patenting companies, by state and by year. Finally, in a state-by-year panel, we regress state tax rates (for each of our four tax variables) on contemporaneous and lagged values of the percentage change in market capitalization of these companies, along with state and year fixed effects.

The results are shown in Appendix Tables A2-A5. We find no evidence that any of these state tax policies is systematically associated with the recent fortunes of local patenting companies.

Another potential concern is the possibility that changes in economic policies other than taxes are correlated with taxes. For example, a pro-business state legislature could both cut taxes and relax state level regulations on labor and the environment. In this case, our models would likely overestimate the true effect of taxes. In this respect, models that control for state of origin*year effects or state of destination* year effects are informative of the amount of bias. For example, if an origin state both cut taxes and regulations, a model that includes origin*year effects will account for it.

Of course, we can't rule out with certainty that there are other omitted determinants of changes in migration flows that are correlated with changes in taxes. We provide indirect evidence on the validity of our estimates with four specification tests.

First, we exploit the exact timing of tax changes and we test for pre-trends.

Second, we provide a specification test based on the fact that corporate taxes should affect some scientists more than others:

(i) On the most obvious level, changes in corporate taxes and the ITC should affect scientists in the corporate sector but should have a more limited effect on scientists employed by universities, government agencies, and other non-profit research institutions which are not subject to corporate taxation. ${ }^{21}$

(ii) Non-corporate inventors provide an even sharper test: they should not be sensitive to corporate taxes and ITC but they should be sensitive to the ATR and possibly R\&D tax credits.

(iii) Moreover, we exploit variation in the apportionment formula. A testable hypothesis is that corporations' demand for labor, including star scientists, should be sensitive to corporate tax rates

\footnotetext{
${ }^{21}$ It is in principle possible that academic scientists may hope to commercialize their inventions and may prefer to do so in a place with low corporate taxes. Even so, it is reasonable to expect that the effect of corporate taxes is significantly stronger for corporate scientists whose employers are directly subject to such taxes.
} 
in states where payroll is one of the primary apportionment factors and should be less sensitive in other states.

Third, we estimate models that exploit the longitudinal nature of our data and include firm fixed effects. These models focus on firms that have a presence in multiple states. We test whether a given firm with operations in multiple states changes the share of scientists it employs in each state when relative state taxes change. Thus, these models absorb all permanent unobserved differences across firms. Finally, in an effort to investigate whether individual heterogeneity might play a role, we estimate an individual-level destination choice model that includes scientist fixed effects.

\section{(B) Non Random Selection}

In our data, not all origin-destination state pairs exhibit positive migration flows in every year and some state pairs never exhibit a positive flow. Origin*destination*year cells with a zero flow are necessarily dropped from the estimation because their outmigration log odds-ratio is undefined. A concern is that our parameters are being estimated only for the sample of state pairs that are "similar enough" to have some marginal scientists close to being indifferent between the two states. State pairs that are so "different" that all the scientists are inframarginal (and hence never move between them) do not contribute to the estimation. Even if the parameter estimates are unbiased for the selected sample of cells with non-zero frequencies, they may not be representative if the missing cells are not random.

Put differently, the reported coefficients might describe well the effects of tax differentials across states that are sufficiently similar to have top scientists indifferent at the margin, but might not describe well the effects of tax differentials across states that are very “different”. For example, consider two origin-destination pairs: California-Washington, which has a large flow of star scientists every year, and Nevada-Vermont, which has some years with zero flow. If Washington and Vermont increase their net-of-tax rates in a given year, the California-Washington flow may rise while the Nevada-Vermont flow remains at zero. This latter "zero" effect will not be reflected in our estimates because the Nevada-Vermont log odds ratio is undefined in that year, leading to an upward bias in the tax elasticity. Of course, there is no reason to expect that missing cells are necessarily only associated with tax cuts. If Washington and Vermont decrease their net-of-tax rates, the California-Washington flow may fall while the Nevada-Vermont flow remains at zero; the latter "zero" effect of a tax increase also will not be reflected in our estimates, leading to a downward bias. 
To see graphically the potential for bias, consider Appendix Figure 4. As in the right panel of Figure 4, each panel plots the log odds ratio on the y-axis against the net of tax differential on the x-axis, but for a hypothetical data set. Each dot represents a hypothetical origin-destination-year cell. Assume that the four blue dots on the x-axis are not in the estimation sample, as in the NevadaVermont example. Dots to the right (left) of the y-axis represent cases of an increase (decrease) in the net of tax rate in the destination state relative to the origin state. For each hypothetical data set, the blue line has slope equal to the true effect of tax differentials on mobility in the population, $\eta$. By contrast, the slope of the red line is the estimated effect. It differs from the true slope because it ignores the blue dots. In the top panel, the estimated slope is lower than the true one (downward bias). In the bottom panel, the opposite is true (upward bias). Thus the figure illustrates that the bias can be either positive or negative. The bias depends on the relationship between residual (vertical distance between dots and the line) and net-of-tax rates (conditional on controls such as pair and year fixed effects).

To see under what conditions cells might be missing, assume for simplicity that there are only two states, $o$ and $d$. The $\log$ odds-ratio $\log \left(P_{\text {odt }} / P_{o o t}\right)$ is non-missing only if there is at least one scientist moving from state $o$ to state $d$ in year $t$. Utility in state $d$ is higher than state $o$ for at least 1 scientist if

$$
\max \left[e_{\text {iodt }}-e_{\text {ioot }}\right]+\alpha\left[\log \left(1-\tau_{d t}\right)-\log \left(1-\tau_{o t}\right)\right]+\alpha\left[\log \left(w_{d t} / w_{o t}\right)\right]+\left[Z_{d}-Z_{o}\right]>C_{o d}
$$

where max is defined over all scientists $i$ who live in state $o$. Intuitively, a origin-destination-year cell is non-missing if the utility gains from moving from $o$ to $d$ for the individual with the strongest idiosyncratic taste for state $d$ compared to state $o$ exceed the cost of moving. The utility gains from moving are the sum of the elements on the left hand side of equation (5) - namely the gains stemming from idiosyncratic preference, tax, wage and amenity differences. The individual with the strongest idiosyncratic taste for state $d$ compared to state $o$ is the one with the largest [ $\mathrm{e}_{\text {iodt }}-$ $\left.\mathrm{e}_{\text {ioot }}\right]$ difference.

Similarly, the $\log$ odds-ratio $\log \left(P_{\text {odt }} / P_{\text {oot }}\right)$ is also non-missing if there is at least one firm moving from state $o$ to state $d$ in year $t$. In turn this requires that

$$
\max \left[v_{\text {iodt }}-v_{\text {ioot }}\right]+\beta\left[\log \left(1-\tau^{\prime}{ }_{d t}\right)-\log \left(1-\tau^{\prime}{ }_{o t}\right)\right]-\beta\left[\log \left(w_{d t} / w_{o t}\right)\right]+\left[Z^{\prime}{ }_{d}-Z^{\prime}{ }_{o}\right]>C{ }^{\prime}{ }_{o d}
$$

where max is defined over all firms located in state $o$. This requires that the profit gains from moving from $o$ to $d$ for the firm with the strongest productivity match in state $d$ compared to state $o$ exceed the cost of moving. The profit gains from moving are the sum of the elements on the left 
hand side of equation (6) - namely the gains stemming from the productivity match, tax, wage (with minus in front) and productive amenity differences.

In estimating equation (3), the magnitude of the bias generated by missing cells depends on $\mathrm{E}\left\{u_{o d t} T_{\text {odt }} \mid T_{\text {odt }}\left[\log \left(1-\tau_{d t}\right)-\log \left(1-\tau_{o t}\right)\right], T_{\text {odt }}\left[\log \left(1-\tau_{d t}^{\prime}\right)-\log \left(1-\tau_{o t}^{\prime}\right)\right], \quad T_{\text {odt }} \gamma_{d}, T_{o d t} \gamma_{o}, T_{o d t} \gamma_{o d}\right\}$, where $T_{\text {odt }}$ is an indicator for whether (5) or (6) hold. In Section 5.5 below, we provide evidence suggesting that there is no systematic relationship in our data between the net-of-tax rate differentials and the probability of a potential cell being missing.

\section{Main Empirical Results}

\subsection{Graphical Evidence: Scatterplots}

In Figure 4 we show a series of bin-scatterplots of the log odds-ratio against the log net-of-tax rate after conditioning on state-pair and year fixed effects. In other words, we demean the log oddsratio and the log net-of-tax rate by their within-pair and within-year sample means. The two panels on the far left show outmigration between a given origin-destination pair versus the indicated netof-tax rate in the origin state. The two panels in the center use the destination state's tax rate on the $\mathrm{x}$-axis. If taxes affect the migration decisions of scientists, one would expect the relationship between origin net-of-tax rates and outmigration to be negative, as higher net-of-tax rates in the origin state (i.e. lower taxes in origin state) result in less outmigration. Similarly, one would expect the effect of destination net-of-tax rates to be positive, as higher net-of-tax rates in the destination state (i.e. lower taxes in destination state) result in more migration to that state. Empirically, this is what we observe.

The two panels on the far right of the figure show the same type of bin-scatterplots except that the measure on the x-axis is now the difference between the destination state's log net-of-tax rate and the origin state's log net-of-tax rate. This specification is equivalent to those in the first four panels, but it is more parsimonious in that it forces the effect of tax changes in the origin and destination state to be the same but of opposite sign. The plots shows that higher destination-origin net-of-tax rate (after-tax income) differentials are associated with higher origin-to-destination migration.

\subsection{Graphical Evidence: Timing}


In Figure 5 we present evidence on the timing of the effect and the existence of pre-trends with a simple non-parametric graph. Each panel shows the difference in star scientist outmigration (relative to the year (0) prior to the tax change) between observations in which the destinationorigin tax differential changes and those in which it does not. We plot this difference for a number of years before and after the tax change event. The left panel is for personal income taxes (ATR at $99^{\text {th }}$ percentile); the right panel is for corporate taxes.

As discussed above, our key identifying assumption is that the migration flows of scientists for state pairs in which their tax differential changes would be, if not for the tax change, similar to those for pairs in which the tax differential did not change. An obvious starting point for probing the validity of this assumption is to see whether migration flows for these two groups is similar in the years before a tax differential change.

For parsimony, in the graph we impose symmetry. That is, we restrict the migration response to a tax differential decrease to be equal, but of opposite sign, to the response to a tax increase. Specifically, the graph plots the estimated coefficients $\beta_{h}$ from a series of regressions - one for each horizon, $\mathrm{h}-$ of the outmigration log odds-ratio in $t+h$ relative to the its value in the year prior to the tax change $(t)$ on an event indicator $D_{\text {odt }}$ :

$$
\log \left(P_{\text {odt } t h} / P_{\text {oot }+h}\right)-\log \left(P_{\text {odt }} / P_{\text {oot }}\right)=\beta_{h} D_{\text {odt }}+\mathrm{e}_{\text {odt }}
$$

where $D_{\text {odt }}$ takes the value 1 if the destination-origin differential in the net-of-tax rate increases between $t$ and $t+1,-1$ if the differential decreases between $t$ and $t+1$, and 0 if the differential does not change.

Consider the case of a tax hike in the origin state or, equivalently, a tax cut in the destination state, so that $D_{\text {odt }}=1$. The coefficients plotted in the Figures measure how much outmigration from origin to destination increases in state pairs where the tax differential changes relative to state pairs where the tax differential does not change. For example, a positive coefficient in period $h=3$ means that outmigration 3 years after the tax change has increased relative to outmigration in the year just before the tax change in state pairs where the tax change took place compared to state pairs where the tax change did not take place.

Essentially, this is a difference in difference specification for each year since the tax change. The coefficient is set equal to 0 at $h=0$ (i.e. the year just before the tax change) by construction. A similar interpretation applies to the case of a tax cut in the origin state or a tax increase in the 
destination state in year $t$, so that $D_{o d t}=-1$. To minimize noise, we focus on a balanced panel of pairs with data from 5 years before an event to 10 years after, and we focus “permanent” tax changes - defined as changes that are not reversed for at least the next 5 years. ${ }^{22}$

The plot for personal taxes in the left panel of Figure 5 shows three important features of the data. First, we uncover no obvious pre-trend. In the five years leading up to the tax change, scientist mobility is not trending upward or downward in any visible way relative to other states. Second, in the years after the tax change, outmigration increases: scientists appear more likely to move from one state to another when taxes in the destination state fall relative to the origin state. The dashed horizontal line indicates the average coefficient over the pre-treatment period. Thus the difference between the dashed line and the dots in the years after the tax change is a measure of the average effect of the tax change on mobility. Third, the full effect of the tax change does not manifest itself immediately after the tax change; it tends to grow over time.

We see similar patterns for business taxes. Our main variable of interest for business taxes is CIT, shown in the right panel of Figure 5. Here too we see no pre-trend, and an increase in outmigration after the tax change. This increase is partially reversed after 5 years. While the effect appears visually smaller for CIT than ATR, we cannot directly compare the magnitudes of their effects yet, since for now we are using an indicator for tax change events, and therefore ignoring the magnitude of the tax change. The average tax change could be different for ATR and CIT. ${ }^{23}$

Investment tax credits also present clear evidence of the timing of the effect (Appendix Figure 5, left panel). The picture that emerges from the R\&D tax credits graph is somewhat more mixed. Unlike the other three, it visually seems to suggest that it might display a small positive pre-trend. (Appendix Figure 5, right panel). We can't reject that the pre-trend is statistically equal to zero. For completeness, in Appendix Figures 6-7, we also show analogous graphs based on the stock of scientists in a given state before and after a tax change in that state.

\footnotetext{
${ }^{22}$ To further reduce noise, for the ATR, we exclude very small tax differential changes by keeping only changes of at least 1 percentage point in absolute value. Unlike for our other three tax variables---CIT, ITC and R\&D credit---the exact value of the ATR in any given state changes nearly every year in our data both because of the nominal income of our hypothetical taxpayer changes every year and because of minor changes to federal tax exemptions and deductability. These small changes are not a problem for our main models because, in those models, we focus on slope parameters, and therefore make full use of information on the magnitude of the change. But tiny tax changes add significant noise in models with dummy variables, like the one used here.

${ }^{23}$ Adding controls to Figure 5 does not change the results. Specifically, adding for the full vector of controls that we use in our baseline regression (column 6 of Table 2a) results in a graph that is almost identical to the one shown here and has tighter confidence intervals.
} 
Figure 5 is intended to present simple, non-parametric evidence on the evolution of mobility. Since in this Figure we uses a dummy variable to measure tax changes, the Figure does not exploit information on the magnitude of tax changes. In Section 5.8 below we will come back to the timing of the effect and show analogous Figures that are more tightly linked to our econometric model in Section 3. Those graphs differ from the ones above because they make full use of information on the magnitude of the effect and because they also include all the controls that we use in the regressions.

\subsection{Baseline Regressions}

The baseline regression results are shown in Table 2a. The table shows variants of equation (3).

Each column represents a regression of the outmigration log odds-ratio on the log differential of the net-of-tax rate between the destination and origin states, for each of our four tax variables. In this and all the other tables, we simultaneously include all four tax variables: personal income tax variable along with the three business tax variables jointly in the same regression.

All regressions contain year fixed effects. The regression underlying column (1) does not condition on state or state-pair fixed effects and therefore is based on cross-sectional variation. The estimated coefficient on the net-of-tax rate on corporate taxes is negative, contrary to expectations of a positive effect from after-tax income. Column (2) adds state of origin and state of destination fixed effects, while column (3) adds state-pair fixed effects. Now the coefficients on all net-of-tax rate variables becomes positive and statistically different from zero at conventional levels. Column (3) is equivalent to the fit lines shown in the two far-right panels of Figure 4. Next, we add a yearspecific fixed effect for the region of the origin state (using Census Bureau's nine-region categorization)(column 4), a year-specific fixed effect for the region of the destination state (column 5), a year-specific fixed effect for the pair defined by the origin region and destination region (column 6).

Our preferred specification is that of column (6), which absorbs both state-pair permanent characteristics as well as time-varying year-specific shocks that are specific to each region-pair. The coefficients on the $99^{\text {th }}$ ATR and CIT net-of-tax rate are 1.89 and 1.93 , respectively. Both are significant at the $1 \%$ level. The coefficients on the investment credit is 1.73 . The coefficient for the R\&D credit is much smaller - only 0.40 - and significant only at the $10 \%$ level. 
Given the average probability of moving in our sample, the implied elasticities of the moving probability with respect to the $99^{\text {th }}$ ATR and CIT net-of-tax rate are 1.76 and 1.85 , respectively (equation (4)). To get a sense of the magnitude of our estimated elasticity, we estimate the implied increase in star scientists in New York following that state's 2006 cut in its personal income tax rate. New York cut its statutory rate for the top tax bracket from 7.5\% to 6.8\%, which resulted in a decline in our measure of the $99^{\text {th }}$ percentile ATR (federal plus state) from $32.4 \%$ to $32.0 \%$, or a $0.6 \%$ increase in the net-of-tax rate. An elasticity of 1.76 implies that the long-run effect of this tax cut will be a decline in New York's outmigration rate of star scientists by 1.1 percentage points (p.p.). It also implies an increase in New York's inmigration rate of 1.1 p.p., so an increase in net migration rate of 2.2 p.p.. New York's outmigration rate and inmigration rate were each about 5.9\% in 2005 (66 stars coming and 66 stars going from a stock of 1,118 stars). Thus, the effect of this tax change is to increase New York's net inflow of star scientists by about 3.0 per year. ${ }^{24}$

Of course, these elasticities are naturally large due to the small base of scientists who move in each year. The elasticities of the stock of scientists with respect to taxes are necessarily smaller, because the base is much larger. These are the relevant elasticities from the point of view of a revenue maximizing state planner. We calculate that the implied elasticities of the stock of scientists with respect to the $99^{\text {th }}$ ATR and CIT net-of-tax rate are .40 and .42 respectively. To be precise, the way to interpret these elasticities is: if after-tax income in a state increases by one percent because the personal income average tax rate or the corporate tax permanently decline, the stock of scientists in the state experiences a percentage increase of 0.4 or 0.42 percent per year forever, everything else constant. ${ }^{25}$ In our New York example, the 0.4 stock elasticity implies a $0.26 \%$ change per year in New York's stock of star scientists. Over time, these effects can be large. For instance, over ten years, the increase net inflow of star scientists of 3 per year means 30 additional star scientists living in New York, a 2.6\% increase in its stock. In practice, of course, everything else in the state economy rarely remains constant, and relative tax changes are almost never permanent.

\footnotetext{
24 Our estimated elasticities for personal income taxes are in line with those by Kleven, et al. (2014). They find that the elasticity of the number of top earners who move to Denmark with respect to taxes is between 1.5 and 2. Our estimates are larger than the ones by Akcigit et al. (2015). They find an elasticity of the number of domestic and foreign inventors with respect to the personal income tax rate equal to 0.03 and 1, respectively, significantly lower than ours. We note that estimates based on within country mobility and estimates based on international mobility do not necessarily need to be similar, since moving across international borders entails larger costs than moving across US states. Moreover, our estimates reflect the long term effect of taxes, which are larger than the short run effects.

${ }^{25}$ The stock elasticity is the flow elasticity times the gross flow (flow(o to d) + flow(d to o)) divided by the base stock of scientists. The average ratio of the gross flow to the stock in our sample is 0.238 .
} 
For completeness, in the last two columns, we add a year-specific fixed effect for the origin state (column 7), and a year-specific fixed effect for the destination state (column 8). These models are almost fully saturated. They generally confirm the qualitative picture that emerges from column 6. While precision declines, the net-of-tax rate effects on outmigration remains positive except those involving ATR in column 7 and R\&D tax credit in column 8.

We also repeat the regressions in Table 2a using two alternative measures of the personal tax rate. First, we use an alternative measure of the ATR using a different approach to constructing the hypothetical taxpayer used for eliciting federal and state tax liabilities from the NBER's TaxSim tax simulator. As described in Section 2, our baseline approach to eliciting the ATR for a given income percentile from TaxSim requires only data on primary-taxpayer wage earnings and longterm capital gains for that percentile. As an alternative approach, we use the NBER's yearly samples of federal tax returns from the IRS statistics on income. These returns do not identify state of residence, so they cannot be used to obtain state-specific inputs, but they can be used to calculate national averages of other TaxSim inputs such as number of dependent exemptions, charitable donations, mortgate interest payments, and rental income (Bakija and Gentry, 2014). See the Online Data Appendix for full details. The results using this alternative measure of the ATR are shown in Table $2 \mathrm{~b}$. The results are quite similar to those in Table 2a, though the estimated elasticity of the outmigration odds-ratio for the ATR net-of-tax rate generally is slightly lower. Standard errors are also lower.

Second, Appendix Table A6 shows models where personal income taxes are measured based on the marginal tax rate for taxpayers in the top $1 \%$ of the distribution, instead of their average tax rate. As we argue above, ATR is the variable that a rational fully-informed taxpayer should consider when deciding where to locate, but the MTR is more visible and salient. The results are generally similar. This is not surprising given that the within-state correlation between the $99^{\text {th }}$ percentile ATR and the $99^{\text {th }}$ MTR is high: a regression of the former on the latter, with state and year fixed effects, yields a slope coefficient of 0.41 with a t-statistic of $39 .^{26}$

Next, we relax the assumption that destination and origin taxes have symmetric effects on pairwise migration. We repeat the regressions underlying Table 2a but allow the coefficient on log

\footnotetext{
${ }^{26}$ We have also estimated models where we include one tax variable at a time (available on request). The point estimates are generally similar to those found in Table 2a. There is little correlation in changes in different taxes over time. For ATR and CIT, the correlation between mean-differences is around 0.01 and is not different from zero.
} 
net-of-tax rate in the destination state to be different than that in the origin state. The results are shown in Table $3 .^{27}$ Column (1) shows the results of a specification including state-pair fixed effects while column (2) adds region-pair*year fixed effects. These models are somewhat less precise, because they do not impose the symmetry assumption, but still informative.

For individual and corporate net-of-tax rates, we find evidence of a negative and significant effect from the origin state net-of-tax rate. That is, fewer star scientists move out of their current state of residence as net-of-tax rates, and hence after-tax incomes, rise there. Moreover, we find that migration of star scientists into a given state tends to rise as its net-of-tax rate increases, though the magnitude of this effect is smaller and not significant for the ATR. The finding that the effect of net-of-tax changes in the origin state is larger than the effect in the destination state might indicate that individuals have more information on taxes in their state of residence - after all, there are 50 potential destination states, and they frequently change their rates.

For the two tax credit variables, the relative importance of destination and origin state taxes is reversed, with the origin state effect smaller. The fact that tax incentives have a stronger "pull” effect is probably not too surprising: tax credits are specifically designed to attract and targeted to out-of-state businesses doing site selection searches and are often advertised to specific industries and even specific firms. Results based on the MTR are generally similar (Appendix Table A6.)

\subsection{Non-Random Selection}

In our data, all states have at least one star in virtually every year. But not all origindestination state pairs exhibit positive flows in all years. Overall, only $18 \%$ of all possible origin*destination*year triplets have a positive flow, and this fraction varies somewhat over time. Appendix Table A8 shows for each year the number of state pairs with no migration flow. Appendix Table A9 shows for each origin-destination pair the number of years with no migration flow. Not surprisingly, state pairs involving sparsely populated states such as Alaska, South Dakota, or Wyoming tend to exhibit few if any star scientists moves over the sample period.

As discussed in Section 4, one potential concern is the possibility of bias. To better understand the implications of the missing cells, we turn to two pieces of evidence. First, we test whether the presence of cells with zero mobility flows is systematically associated with tax

\footnotetext{
${ }^{27}$ For these specifications we cannot include either origin-state*year fixed effects or destination-state*year fixed effects as that would leave no variation with which to identify the coefficients of interest.
} 
increases or tax cuts. In Appendix Table A10, we regress the probability of a missing cell on netof-tax rate differentials, conditioning on our baseline controls. The estimated coefficients are both individually and jointly not distinguishable from zero, indicating that there is no systematic correlation. This lack of correlation is reassuring, because it indicates that whatever selection there is in the data is not systematically correlated with tax changes, suggesting any bias is likely to be minimal.

As a second piece of evidence, in Table 4 we estimate models based on cells with an increasingly small number of scientist moves. Entries show that estimates based on our full sample (column 1) are generally similar to estimates based on the sample of cells where only 1 scientist moves (column 2). For example, the coefficients on ATR and CIT net-of-tax rates change from 1.89 and 1.93, respectively, to 1.92 and 2.10. The same is true for models based on the sample of pairs for which we have no more than 2, 4, 6, 8 or 10 scientists (columns 3 to 10). Overall, there appear to be little relationship between number of observed moves in a cell and the magnitude of the estimated tax elasticity. The stability of the coefficients in the table is reassuring.

Of course we do not know what our estimates would be if we included the cells that are missing due to the absence of any move. But based on these two pieces of evidence we conclude that in practice the magnitude of the problem might be limited.

\subsection{Specifications Tests}

The results in Table 2a indicate a strong effect from the personal ATR, the corporate income tax rate, and the investment tax credit rate and a more modest effect from the R\&D tax credit. To mitigate concerns that these results reflect some spurious correlation, we perform several additional tests.

Specification Tests for Business Taxes. We now consider several specification tests based on business taxes. First, we exploit the fact that states vary in whether, and how much, employment location matters for corporate taxation of companies generating income in more than one state. As we described in Section 2.2, a corporation in a given state must determine what share of its national taxable income to apportion to that state based on the state's apportionment formula, which is a weighted average of the state's shares of the company's national payroll, property, and sales. The weight on employment (payroll) varies across states and over time, and ranges from zero to onethird. With a zero weight, a corporation's tax liability in a given state is independent of its level of 
employment in that state (conditional on having a tax liability in that state at all). Therefore, a testable hypothesis is that corporations' demand for labor, including star scientists, should be more sensitive to corporate tax rates in states with larger apportionment weights on payroll.

To test this hypothesis, we construct an indicator variable that equals one if the origin state, in that year, has a payroll weight equal to the traditional formula's one-third weight and that equals zero otherwise. (About half of our sample have a one-third payroll weight; the other half generally have either zero or 0.1.) We construct an analogous variable for destination states. We then estimate models that include these two indicator variables as well as their interactions with the origin and destination CIT net-of-tax rates. The results are shown in Table 5. The negative coefficient on the interaction between the payroll dummy and origin state CIT indicates that the origin state's net-oftax corporate rate reduces outmigration significantly more in origin states with a relatively high apportionment weight on payroll. Similarly, the positive coefficient on the interaction between payroll dummy and destination state CIT indicates that the destination state's net-of-tax corporate rate increases migration to that state significantly more when the destination state has a high payroll weight. The results are robust to conditioning on non-CIT rates (see column 2).

At the bottom of the table we show the Implied Origin CIT Effect, which is the sum of the coefficients in rows 1 and 3; as well as the Implied Destination CIT Effect, which is the sum of the coefficients in rows 2 and 4 . The implied overall effect of CIT on mobility for states with positive payroll weight is quite large. By comparison, the overall effect of CIT on mobility for states with states with zero payroll weight - shown in the top two rows - is indistinguishable from zero. Thus, the CIT has a strong effect on employment only in states where the tax liability is a function of firm employment, and has a smaller, possibly zero, effect in other states.

We now investigate whether migration of star scientists who work in the private sector are more sensitive to business taxes than are scientists who work for not-for-profit organizations, like academia and government. The COMETS patent database classifies the organization type of the patent owner into the following categories: firm, academic institution, government, or other. Furthermore, it identifies the actual name of the organization. This allows us to additionally screen out firms that appear to be pass-through entities (such as S corporations) and not standard C corporations, and therefore are not subject to the corporate income tax. Specifically, we screen out organizations (patent assignees) whose name in the patent record contains "limited liability corporation," "limited liability partnership", and related abbreviations. 
The results are shown in Table 6. We find that corporate income taxes and the investment tax credit significantly affect migration for star scientists working for corporations (after excluding clear pass-through organizations; column 2) but have no significant effect on migration of stars working for academic or governmental institutions (column 3). This likely reflects the fact that universities and government agencies are not subject to corporate income taxes and cannot benefit from the investment tax credit.

Interestingly, mobility of academic and government scientists also appears insensitive to changes personal income taxes. This stands in contrast to mobility of corporate scientists, which has a coefficient of 2.43. While we can't be certain, it is possible that academic and government scientists are less affected by pecuniary motives than their corporate counterparts who, after all, self-selected into a form of employment than typically offers higher pay. ${ }^{28}$

In Column (4), we look at migration of individual inventors - that is, patenters who own their own patent rather than assigning it to some organization. Consistent with the fact that these inventors would not be subject to the corporate income tax rate, their migration appears to be insensitive to the corporate income tax rate. ${ }^{29}$ In most states, both individual and corporate income taxpayers can claim R\&D tax credits for qualified expenditures. Many individual inventors may have non-trivial $R \& D$ expenditures (especially given that $R \& D$ includes their own labor expenses) and hence could be sensitive to the $R \& D$ tax credit. The results in column (4) suggest this is the case: the coefficient on the investment net-of-tax credit rate is insignificant while the coefficient on the R\&D net-of-tax credit rate is relatively small but statistically significant. ${ }^{30}$

We attempted to identify pass-through entities based on the name of the firm reported on the patent application. Unfortunately, the pass-through sample is too small to allow meaningful estimates. The small sample size reflects the fact that we are only able to identify pass-throughs if they have an obvious identifier like “Limited Liability," “LLP”, or "LLC” in their organization name listed on the patent (under patent assignee). Moreover, pass-through entities, while common

\footnotetext{
${ }^{28}$ It is also possible that higher state income taxes may be associated with higher funding for publicly funded universities.

${ }^{29}$ The only case in which CIT would matter for an individual inventor is the case where the inventor plans to create a firm in the future and is forward looking enough to take future CIT into consideration.

${ }^{30}$ While not shown in these tables, we also estimated the effect of the individual income net-of-tax rate, for the $99^{\text {th }}$ percentile, on migration of individual inventors. This net-of-tax rate has a coefficient of 2.08 (with a standard error of 0.67), roughly similar to the coefficients on the individual ATR from the full sample.
} 
for professional services (doctor, lawyers, etc.), are not very common in high tech fields. We also miss all pass-through subsidiaries of large firms, if patents are filed under the parent firm.

\subsection{Property and Sales Taxes}

Business and personal income taxes are not the only taxes that vary by state. It is in principle possible that property or sales taxes might play a role in mobility decisions. If states that change personal income or business taxes also tend to systematically change property or sales taxes, our estimates would be biased.

In Table 7 we show models that include personal income taxes and business taxes as well as property and sales taxes. To our knowledge, there is no comprehensive state panel data on effective property taxes, likely due to the complexity and wide variety of property tax systems across the U.S. (e.g., in how the property tax base is defined). Thus, we simply use the ratio of state and local government property tax revenues to aggregate personal income, in a given state and year, as a crude measure of the effective property tax rate. We obtained data on state sales tax rates from Fajgelbaum, et al. (2015). These data cover sales taxes levied by state governments, but not by local governments within the state (which are not uncommon). A limitation to keep in mind is that, unlike our data on personal income and business taxes, which are of good quality, the quality of available data on property taxes and sales taxes is not ideal. It would be better to separate out personal and business property taxes, and get something closer to an effective sales tax burden (accounting, for example, for the fraction of state consumption subject to sales taxes and for local sales taxes) instead of a statutory rate.

With these limitations in mind, Table 7 indicates that our baseline estimates are not very sensitive to conditioning on sales and property net-of-tax rates. For example, a model that conditions on property taxes in column 2 yield coefficients for ATR, CIT, ITC and R\&D net-of-tax rates of 1.38, 2.03, 1.53 and 0.40 , respectively. A comparison with our baseline estimates (reproduced in column 1) suggests that our estimates appear generally robust. Models that condition on both property and sales taxes are even closer to the baseline (see column 3).

In principle, the effect of property taxes is not necessarily identical to the effect of income taxes. For one, property taxes are probably in part capitalized into property values. Thus, from the point of view of someone moving to a state in response to a tax change, a higher property tax is in part offset by a lower cost of housing. Moreover, only part of household income is spent on housing. 
Similarly, only some consumption expenditures are taxed: health, education, food consumed at home, rents and mortgages are typically not subject to sales taxes.

In practice, the estimated coefficient on property taxes is positive, with an implied elasticity of .53 - this is lower than other elasticities, possibly due to capitalization into land prices. By contrast, the estimated coefficient on the sales net-of-tax rate is negative - opposite of what one might expect. Taking it at face value, it would imply that holding personal income taxes, business taxes, and property taxes constant, a higher sales tax rate in a state (relative to other states) makes that state more attractive to star scientists. We do not have a good explanation. We note, however, that unlike state income taxes - which are generally progressive - sales taxes are regressive. Thus, their effect on top earners may be different.

In column 5 we show estimates based on a specification where we combine property and sales tax data into a single effective tax rate. Specifically, we define the "effective consumption tax rate" (ECTR) based on the share of income spent (1) on consumption goods subject to sales taxes and (2) on housing (subject to property taxes): ECTR $=(1-\mathrm{ATR}) * 0.3 * \mathrm{STR}+\mathrm{PTSHR}$, where STR is the sales tax rate and PTSHR is property taxes as a share of income. ${ }^{31}$ The coefficient on the log of the ECTR net-of-tax rate is 0.54, similar to the one in column 2, and statistically significant, indicating that the combined effect of sales and property taxes has the expected sign. Finally, in column 6 we use an "effective personal tax rate" that combines ATR, property and sales taxes and is defined as ATR + ECTR. The coefficient drops to 0.29 and remains statistically significant.

\subsection{Robustness}

In this section, we assess whether our findings are robust to a number of alternative specifications and alternative samples.

We begin in Table 8 by probing the robustness of our baseline estimates of the standard errors to alternative assumptions regarding the correlation among residuals. Recall that our baseline model

\footnotetext{
${ }^{31}$ Define the share of income spent on goods subject to sales taxes and on housing, respectively as $\mathrm{w}_{\text {sales }}$ and $\mathrm{w}_{\text {housing. }}$. The remaining share of income, $1-\mathrm{w}_{\text {sales }}$ - Whousing, is either saved or spent on non-taxed goods like education and health. Consider a worker who receives $\$ 1$ in income. He first pays ATR in income taxes, leaving (1 - ATR) for consumption and saving. He spends (1-ATR)* $\mathrm{W}_{\text {sales }}$ on goods subject to sales taxes and (1-ATR)* $\mathrm{W}_{\text {housing }}$ on housing. We assume $\mathrm{w}_{\text {sales }}=0.3$ (based on evidence that high income households typically spend about $30 \%$ of their income on housing (Moretti 2013 based on CEX data) and assuming star scientists have a saving rate around 0.2 and spend $20 \%$ of their income on goods not subject to sales taxes). The total tax payment as a share of income then amounts to ATR + (1-ATR)* $\mathrm{W}_{\text {sales }}{ }^{*} \mathrm{STR}+(1-\mathrm{ATR}) * \mathrm{w}_{\text {property }}{ }^{*}($ property tax rate). Notice this last component, (1ATR)* $\mathrm{W}_{\text {property }} *$ (property tax rate), is simply property tax revenues as a share of income (PTSHR).
} 
(reproduced in column 1) allows for residuals to be clustered, within origin-state*year, destinationstate*year and state-pair.

Columns 2 to 7 are based on six variants of the Driscoll and Kraay (1998) estimator described in Section 3.3. In column 2, we use the Driscoll-Kraay estimator with autocorrelation up to one lag. In columns 3 to 7, we increase the number of lags for autocorrelation from two to six. Although the assumptions on serial correlation of residuals are different from those of the baseline model, the estimated standard errors are generally similar.

In Column (8), we use two-way clustering by origin and by destination. This is an extremely broad level of clustering as it allows for any type of serial correlation of errors across time (even among pairs that are not the same) in addition to the cross-sectional dependence across pairs. This results in about a doubling of the standard errors. We don't use this specification as our baseline because in our view it depends on assumptions that might be overly general - it imposes little restriction on the possible correlation of residuals across pairs in different years. By contrast, threeway clustering by origin-state*year, destination-state*year and state-pair imposes only a mild restriction on serial correlation. As we note in Section 3.3, we cannot reject such a restriction. Thus, we think that in our setting three-way clustering by origin-state*year, destination-state*year and state-pair probably gives a more appropriate characterization of the true precision of the estimates.

Next, we consider whether our baseline results are sensitive to the precise definition of "stars." So far, we have defined stars as scientists in the top 5\% of patent counts over the prior ten years. Appendix Table A11 repeat the same set of regressions as in Table 2a but using a sample where stars are defined as those in the top $1 \%$ or $10 \%$ of the distribution. The results are generally similar to the baseline results. We can also define stars based on citation counts instead of patent counts in order to include scientists that produce fewer but higher quality patents and exclude scientists that produce many but less influential patents. Appendix Table A12 shows that the estimated effects are similar but slightly larger than the baseline results, possibly because these stars have higher average incomes than the baseline set of stars.

In Appendix Table A13 we show how our estimates vary if we use ATR for different income levels. In the top panel we use the $95 \%$ percentile. In the bottom panel we use the $99.9 \%$ percentile. Compared to Table 2a, results are similar for 99.9\%, and larger for the 95\%.

In Appendix Table A14 we focus on additional robustness checks. In column (2), we assess how the baseline results change if one gives more weight to observations from state-pairs with 
larger bilateral migration flows. Specifically, we weight each pair of states based on the average outflow of stars over the full sample. This weighting leads to somewhat larger estimated effects.

Weighting is complicated when errors are spatially or serially correlated. Solon et al. (2015) show that in this situation standard weighting like the one used above could make things worse instead of better, and propose alternative weighting approach. We attempted to follow this approach but were unable to find appropriate weighting variables that were inversely related to the variance of our estimated residual. ${ }^{32}$

In column (3), we condition on current origin and destination state economic conditions via the unemployment rate and the population in each state. We opt not to include these variables in our baseline regressions because they may well reflect endogenous responses of the state economy to changes in state taxes. In column (4) shows that results do not change when we drop post-2006 observations from the sample, indicating that our estimates are not driven by the Great Recession. ${ }^{33}$ In column (5), we use an alternative patent database, constructed by Li, et al. (2014), that applies a disambiguation algorithm to the reported patent inventor names to attempt to separately identify multiple inventors who share a common name and also unique inventors who report their name slightly differently on different patents.

One might be concerned that unobserved individual heterogeneity - like unobserved scientist characteristics - might bias our estimates. Our data allow us to follow scientists over time. We have estimated models that control for individual scientist fixed effects. We were unable to estimate full multinomial logit models (including McFadden’s (1974) alternative-specific logit model), where the dependent variable is the locational choice among 51 possible states and the controls include dummies for each scientist, due to computational constraints and the extremely high number of observations (over 20 million scientist*year*potential-destination observations). However, we were able to estimate the analogous linear probability model (LPM). The estimates in Appendix

\footnotetext{
${ }^{32}$ We began by estimating the un-weighted regression and obtained the residuals. We then regressed the squared residuals on the inverse of the average of outflow for the relevant state-pair over the whole sample period. We obtained predicted values from that regression and used the inverse of those predicted values. The coefficient turned out to be negative, not positive, implying a given observation's variance is not inversely related to the size of the outflows for that pair. We found the same using stock of stars or state population as the regressor.

${ }^{33}$ Some eventually-granted patents are missing in the COMETS patent database because at the time of its construction many patents applied for in 2007 - 2010 (and likely a small number from even earlier years) had not yet been granted and hence are not included in this database. This affects both the numerator and the denominator of the odds ratio that we use as our dependent variable, so it is expected to represent classical measurement error.
} 
Table A15 confirm that personal and business taxes affect mobility, even after conditioning on individual fixed effects.

\subsection{Impulse Response Functions}

So far we have focused on a static model - equation (3). This baseline model is deliberately parsimonious, but it does not allow for any dynamics, nor does it differentiate between short run effects and long run effects. Taken literally, the model would predict that a permanent increase in the net-of-tax rate in a state (a step function in the time series for the rate) would lead to an immediate and permanent increase in the net inflow of star scientists to the state (a step function in the time series for the inflow), all else equal.

However, it is unlikely that the effect takes place immediately, as it may take time for scientists and firms to relocate. Indeed, Figure 5 points to the fact that it may take some time for the effect of tax changes to manifest. Moreover, the effect may not last forever.

We now explore in more detail the timing of the migration responses to tax changes by tracing the impulse response of migration to tax changes. To do so, we shift from the mean-difference model considered in the previous section to a time-difference (e.g., first-difference) model. ${ }^{34}$

We use the direct projections estimator (Jorda 2005) to estimate the impulse response function of outmigration with respect to tax change treatments. Specifically, we estimate the model:

$$
y_{o, d, t+h}-y_{o, d, t-k}=\beta^{h}\left(\tau_{o, d, t}-\tau_{o, d, t-k}\right)+F_{t, R(o), R(d)}+\epsilon_{o, d, t+h}
$$

where the dependent variable is the change in outmigration (log odds-ratio) from before the treatment, $t-k$, to $h$ periods after the treatment. $F_{t, R(o), R(j)}$ represents a year-specific fixed effect for each pair of regions defined by the origin state's region and the destination state's region. We estimate the regression separately for each horizon from $h=0$ to $10 . k$ is the duration of the treatment period. To be consistent with our previous estimates, we condition on region-pair*year effects. To test for pre-trends, we extend this estimator by looking at the association between the treatment (occurring from $t-k$ to $t$ ) and changes in outmigration over intervals prior to when the treatment began (i.e., prior to $t-k$ ).

\footnotetext{
${ }^{34}$ When short-run and long-run effects differ, fixed effects and first differences are not asymptotically equivalent because they put different weights on observations with different values of the coefficients. In other words, migration in year $t$ is a function of a distributed lag of tax rates, not just the contemporaneous tax rate; if we estimate an equation that includes only the contemporaneous tax rate, the asymptotic coefficient on the contemporaneous tax rate is related to the distributed lag coefficients in a way that depends on whether we use fixed effects or first differences.
} 
Long treatment durations are better suited for exploring the full dynamic responses to net-oftax rate shocks. We focus on treatment duration of 3 or 5 years; we also report results for 1 year changes for completeness. First-differences are too high frequency to adequately capture the full effect of tax changes on outmigration: Long run effects are likely larger than short run effects, as it takes time for scientists and firms to relocate (see Section 5.2.) In addition, short-differences, such as a one-year first-difference, are more likely to reflect temporary tax changes or increments of a multi-year phased-in tax change, while long-differences are more likely to reflect permanent tax changes.

Results for the top individual ATR and the CIT are in Figure 6. There are three panels in each figure, one where treatment duration is assumed to be 1 year, one where it is assumed to be 3 years, and one where it is assumed to be 5 years. Results for the R\&D and investment credits are in Appendix Figure 8.

Our preferred specifications are the ones for 3 or 5 years. In these models, the years before treatment are the ones prior to $t-3$ and $t-5$, respectively. For all four tax variables, star outmigration shows no pre-trends. For the individual ATR and CIT, outmigration begins to rise shortly after the treatment period, grows up to about 2-3 years after the end of the tax change, and then slightly declines through the end of the ten-year horizon. For investment tax credit, outmigration begins to rise shortly after the treatment period and then stabilizes. For $R \& D$ credit, the pattern is considerably more mixed, consistent with the weaker estimates uncovered in Table 2a. In models where the treatments are defined by one-year changes, the estimated impulse response is generally positive, but, as expected, too noisy to be informative.

Focusing on the 5-year tax-change models, we find that the dynamic responses to tax changes are not as simple as the step function effect implied by the static model. In particular, for the ATR, CIT, and ITC, a net-of-tax rate increase results in a more gradual increase, with the peak response occuring at least one or two years after the rate change. Also, there is some evidence that the effect, while long-lasting, is not permanent as we see the effect decline somewhat toward the end of the horizon for all three of these taxes. This could reflect the fact that empirically tax rate changes in our data are not necessarily permanent; or it could reflect the fact that within a few years everyone who was at the margin of moving has already moved because of the tax change.

It is informative to consider what these dynamic results imply for the cumulative effect of a tax change over several subequent years. Using the estimates underlying Figure 6 and Appendix Figure 
8, we can calculate the area under the impulse response function for post-treatment horizons to get an estimate of the cumulative effect through the end of the horizon window. If we cumulate the responses in the ATR 5-year change panel in Figure 6 from $t+5$ (end of treatment period) through $t+10$, we obtain a cumulative elasticity of the stock of scientists to the net-of-tax rate of 6.0. In other words, these estimates imply that a permanent 1\% increase in the net-of-tax rate for personal income taking place between year $t$ and $t+5$ would lead to a $6.0 \%$ increase in the stock of scientists by the end of year $t+10$. The cumulative effects for the CIT and ITC are smaller. For the CIT the cumulative stock elasticity is about 3 , and for the ITC the cumulative stock elasticity is a little under 5.

\section{Within-Firm Evidence}

Tax changes might affect firm localization through entry of new firms (either from births or relocation from a different state) or exit of exiting firms (either from deaths or relocation to a different state). For large, established firms with a presence in multiple states, an additional important margin of adjustment is a change in the spatial distribution of employees across establishments in different states. In our data, large patenters with star scientists in two or more states include large companies like GE, IBM, Google and Microsoft. It is possible that changes in state taxes cause a shift in the relative share of scientists that the firm employs in each state.

In this Section, we focus on multi-state firms and study this margin of adjustment. Specifically, we test whether the firm-specific share of top scientists in a given state changes in response to changes in state taxes. In addition to all previous controls, we also condition on firm fixed effects.

As a concrete example, consider a star scientist in our data named Hammam Elabd, employed by G.E in the 1980's and 1990’s. Our data allow us to follow Mr Elabd over time. In the period 1983-1987, Elabd has patent applications for G.E. in New Jersey. But in 1987, California cuts its corporate income tax, while NJ raises its corporate income tax. Possibly influenced by this change in relative taxes, starting in May 1988, Mr. Elabd has patent applications for GE in California. He continues to have patents in California until 2000.

Figure 7 shows the relationship across states between the 1980 to 2005 change in the state's corporate tax rate and the change over the same period in the share of G.E.'s scientists it employs in the state. The relationship is negative, indicating that Mr Elabd's experience is hardly unique: over time G.E. seems to re-allocate its scientists toward states with lower relative business taxes. 
Table 9 quantifies this geographical reallocation more systematically, using data for all corporate firms. The dependent variable in the regressions is a firm's share of top scientists in a given state and year. The Table shows the effect of taxes in a state on the share of top scientists employed by a given firm in that state, conditioning on firm fixed effects. Column 1, shown only for completeness, is for all firms. Column 2 is for multi-state firms and is the relevant one. The results are interesting. We find that the share of scientists in a state is sensitive to state corporate taxes. For multi-state firms, a ten percent increase in the CIT net-of-tax rate results in a 0.72 percentage point increase in the state share. ITC and R\&D tax credits have somewhat smaller effects - 0.44 and 0.28 percentage points, respectively. While the effect of business taxes is both statistically and economically significant, the effect of personal taxes is neither.

Results in this table are to be interpreted as one of the channels through which state taxes affect employment. The table indicates that state corporate taxes affect within-firm labor demand in a state, but state personal taxes do not affect within-firm labor supply to a state. In other words, conditional on having establishments in multiple states, firms shift the relative employment in response to changes in business tax rates toward lower-tax/higher-credit states. But conditional on working for a given firm, workers are unwilling or unable to relocate in response to state personal income taxes.

Combined with our earlier findings in Table 2a above, this indicates that an important channel for the documented effect of business taxes on employment is within-firm geographical reallocation. On the other hand, the documented effect of personal taxes on employment comes entirely from the effect of labor supply on entry and exit of single state firms. ${ }^{35}$

\section{Conclusions}

We uncover large, stable, and precisely estimated effects of personal and corporate taxes on star scientists' migration patterns. The long run elasticity of mobility relative to taxes is 1.7 for personal income taxes, 1.8 for state corporate income tax and 1.6 for the investment tax credit. In terms of stocks, our elasticities imply that if the net-of-tax rate increases in a state (holding other states' rates constant), due to a cut in the personal income average tax rate or the corporate tax, the

\footnotetext{
35 This finding is surprising. In theory one might expect that a multi-state firm's decisions should depend on the cost of putting scientists in different places. A higher personal income tax raises the cost since part of the incidence of the higher personal tax might fall on the firm itself. If wages and productivity are not perfectly aligned within the firm--for example if seniority wage profiles are not identical to productivity---then there might be rents and incidence is more complicated.
} 
stock of scientists in the state will rise by 0.4 or 0.42 percent per year for as long as the increase in the net-of-tax rate differential lasts.

These elasticities are economically large and significantly larger than the conventional labor supply elasticity. The effect on mobility is small in the short run, and tends to grow over time.

While we can't rule out that our estimates are biased by unobserved demand or supply shocks, a number of additional pieces of evidence lend credibility to a causal interpretation of our estimates. First, we find no evidence of pre-trends: Changes in mobility follow changes in taxes and do not to precede them. Second, the effect of corporate income taxes is concentrated among private sector inventors: no effect is found on academic and government researchers. Third, corporate taxes only matter in states where the wage bill enters the state's formula for apportioning multi-state income. No effect is found in states that apportion income based only on sales (in which case labor's location has little or no effect on the tax bill). We also find no evidence that changes in state taxes are correlated with changes in the fortunes of local firms in the innovation sector in the years leading up to the tax change. Finally, within firm evidence suggests that multi-state firms adjust the share of employment in each state as a function of business taxes.

Overall, we conclude that state taxes have significant effect of the geographical location of star scientists and possibly other highly skilled workers. While there are many other factors that drive when innovative individual and innovative companies decide to locate, there are enough firms and workers on the margin that relative taxes matter.

\section{References}

Alvaredo, F, A Atkinson, T Piketty, and E Saez (2013) “The Top 1 Percent in International and Historical Perspective.” Journal of Economic Perspectives, AEA, 27(3), 3-20

Akcigit Ufuk, Salomé Baslandze, Stefanie Stantcheva "Taxation and the International Mobility of Inventors” NBER Working Paper No. 21024 (2015)

Bakija, Jon, and Joel Slemrod (2004) "Do the Rich Flee from High State Taxes? Evidence from Federal Estate Tax Returns.” NBER Working Papers 10645.

Bakija, Jon and William M. Gentry "Capital Gains Taxes and Realizations: Evidence from a Long Panel of State-Level Data”, mimeo, Williams College, June 2014.

Bakija, Jon and Tarun Narasimhan, "Effects of the Level and Structure of Taxes on Long-Run Economic Growth: What Can We Learn from Panel Time-Series Techniques?”

Bartik, Timothy J. (1991). "Who Benefits from State and Local Economic Development Policies?” Kalamazoo: W.E. Upjohn Institute for Employment Research.

Bayer Pat and Robert McMillan (2012) “Tiebout Sorting and Neighborhood Stratification,” Journal of Public Economics: 96: 1129-43 
Bell, Alex, Raj Chetty, Xavier Jaravel, Neviana Petkova, and John van Reenen "The Lifecycle of Inventors” mimeo, 2015.

Bertrand, Marianne, Esther Duflo, and Sendhil Mullainathan. 2004. "How Much Should We Trust Differences-in-Differences Estimates?” Quarterly Journal of Economics, 119(1): 249-275.

Chirinko, Robert, and Daniel J. Wilson. "State Investment Tax Incentives: A Zero-Sum Game?” Journal of Public Economics 92(12), Dec. 2008, pp. 2362-2384.

Cohen, Roger, Andrew Lai, and Charles Steindel. 2011. "The Effects of Marginal Tax Rates on Interstate Migration in the U.S.” Unpublished.

Cohen, Wes "Fifty Years of Empirical Studies of Innovative Activity and Performance," in Handbook of Economics of Innovation, Vol. 1, 2010, pp. 129-213.

Diamond, Rebecca "Housing Supply Elasticity and Rent Extraction by State Governments,” 2014.

Driscoll John and Aart C. Kraay, 1998. "Consistent Covariance Matrix Estimation With Spatially Dependent Panel Data," The Review of Economics and Statistics, 80(4), pages 549-560.

Duranton, Gilles, Laurent Gobillon \& Henry G. Overman, 2011. "Assessing the Effects of Local Taxation using Microgeographic Data," Economic Journal, vol. 121(555), pages 1017-1046.

Duranton, Gilles, Overman, Henry G., 2005. Testing for localization using microgeographic data. Review of Economic Studies 72 (4), 1079-1106.

Duranton Gilles. “California Dreamin': The feeble case for cluster policies” Review of Economic Statistics, 2011, 3(1), 3-45.

Fajgelbaum, Morales, Suarez Serrato, and Zidar, 2015. "State Taxes and Spatial Misallocation.” NBER Working Paper \#21760.

Faulk, Dagney. "Do State Economic Development Incentives Create Jobs? An Analysis of State Employment Tax Credits. National Tax Journal. 2002.

Gideon, Michael S. (2014). “Uncovering Heterogeneity in Income Tax Perceptions.” Unpublished Manuscript, University of Michigan.

Griliches, Zvi "R\&D and Productivity: The Econometric Evidence” University of Chicago Press Volume, January 1998

Head, K., Ries, J., and Swenson, D., 1999. Attracting foreign manufacturing: investment promotion and agglomeration. Regional Science and Urban Economics 29 (2), 197 - 218.

Helsley, Robert W. and William C. Strange, "Matching and Agglomeration Economics in a System of Cities," Regional Science and Urban Economics, 20,1990, pp. 189-212.

Haughwout, Andrew, Robert Inman, Steven Craig, and Thomas Luce. 2004. "Local Revenue Hills: Evidence from Four U.S. Cities.” Review of Economics and Statistics 86 (2): 570-85.

Jordà, Oscar (2005). "Estimation and Inference of Impulse Responses by Local Projections," American Economic Review, Vol. 95(1), pp. 161-182.

Kaplan, G and S Schulhofer-Wohl (2013) "The Age-Time-Cohort Problem and the Identification of Structural Parameters in Life-Cycle Models.” WP 707, Fed. Res. Bank of Minneapolis

Kirchgassner, G and W W. Pommerehne (1996) "Tax Harmonization and Tax Competition in the European Union: Lessons from Switzerland.” Journal of Public Economics, 60(3), 351-71

Kleven, Henrik Jacobsen, Camille Landais, and Emmanuel Saez "Taxation and International Migration of Superstars: Evidence from the European Football Market” AER 103(5), 2013.

Kleven, H J, C Landais, E Saez, and E A Schultz (2014) “Migration and Wage Effects of Taxing Top Earnings: Evidence from the Foreigners’ Tax Scheme in Denmark” QJE 129(1): 333-78

Liebig, T, P A. Puhani, and A Sousa-Poza (2007) "Taxation and Internal Migration- Evidence from the Swiss Census using Variation in Income Tax Rates.” J. of Reg. Science 
Li, Lai, D’Amour, Doolin, Sun, Torvik, Yu, and Fleming (2014) "Disambiguation and Coauthorship Networks of the US Patent Inventor Database ” Research Policy 43, 941-955.

McFadden, D. L. 1974. "Conditional logit analysis of qualitative choice behavior.” In Frontiers in Econometrics, ed. P. Zarembka, 105-142. New York: Academic Press.

McFadden, D. L. 1978. "Modelling the Choice of Residential Location.” In Karlqvist, A., L. Lundqvist, F. Snickars, and J. Weibull (eds.), Spatial Interaction Theory and Planning Models, 75-96, North Holland: Amsterdam.

Moretti, Enrico (2011). “Local labor Markets,” Handbook of Labor Economics.

Moretti, E, and D. Wilson (2014) "State Incentives for Innovation, Star Scientists and Jobs: Evidence from Biotech", The Journal of Urban Economics, forthcoming

Moulton, Brent R. 1990. "An Illustration of a Pitfall in Estimating the Effects of Aggregate Variables on Micro Units.” The Review of Economics and Statistics, 72(2): 334-338.

Nickell, (1981) "Biases in Dynamic Models with Fixed Effects." Econometrica, 49, 14171426

Schmidheiny Kurt (2006), "Income Segregation and Local Progressive Taxation: Empirical Evidence from Switzerland." Journal of Public Economics, 90(3), 429-458.

Solon, Gary, Steven J. Haider and Jeffrey M. Wooldridge, 2015. "What Are We Weighting For?," Journal of Human Resources, University of Wisconsin Press, vol. 50(2), pages 301-316.

Suárez Serrato, Juan Carlos, “Taxation, Entrepreneurship, and the Choice of Organizational Form” (2014)

Suárez Serrato, Juan Carlos, Owen Zidar "State Corporate Taxes, Firm Mobility, and Innovation Productivity: Evidence from US patent data” (2015)

Suárez Serrato, Juan Carlos, and Owen Zidar (2014), "Who Benefits from State Corporate Tax Cuts? A Local Labor Market Approach with Heterogeneous Firms?”, mimeo, U of Chicago.

Varner, Charles, and Cristobal Young (2012) "Millionaire Migration in California: The Impact of Top Tax Rates.” Working Paper. Stanford University Center on Poverty and Inequality.

Vogelsang, Timothy (2012). "Heteroskedasticity, Autocorrelation, and Spatial Correlation Robust Inference in Linear Panel Models with Fixed-Effects,” Journal of Econometrics, 166(2), 303319.

Wilson, Daniel J. (2009). "Beggar Thy Neighbor? The In-State, Out-of-State, and Aggregate Effects of R\&D Tax Credits.” Review of Economics and Statistics 91(2), 431-436.

Young, Christobal, and Charles Varner (2011) "Millionaire Migration and State Taxation of Top Incomes: Evidence from a Natural Experiment.” National Tax Journal, 64(2, part 1) p255-284

Zucker, Lynne G, Michael R. Darby, and Marilynn B. Brewer, 1998. "Intellectual Human Capital and the Birth of U.S. Biotechnology Enterprises,"AER, vol. 88(1), pages 290-306.

Zucker, Lynne G, Michael R. Darby, "Movement of Star Scientists and Engineers and High Tech Firm Entry”, NBER WP, 2006.

Zucker, Lynne G, Michael R. Darby, and Jason Fong, 2011. “Communitywide Database Designs for Tracking Innovation Impact: COMETS, STARS and Nanobank.”NBER WP 17404. 
Table 1: Average Annual Outflow of Star Scientists, 1997-2006

\begin{tabular}{|c|c|c|c|c|c|c|c|c|c|c|}
\hline Origin State & California & Illinois & Massachusetts & Michigan & $\begin{array}{c}\text { Destination } \\
\text { Minnesota }\end{array}$ & $\begin{array}{l}\text { State } \\
\text { New Jersey }\end{array}$ & New York & Ohio & Pennsylvania & Texas \\
\hline California & 4767 & 13 & 24 & 10 & 9 & 17 & 21 & 8 & 12 & 25 \\
\hline Illinois & 14 & 649 & 4 & 2 & 2 & 2 & 4 & 2 & 2 & 5 \\
\hline Massachusetts & 25 & 3 & 873 & 2 & 3 & 4 & 5 & 2 & 4 & 4 \\
\hline Michigan & 12 & 2 & 3 & 654 & 2 & 2 & 3 & 2 & 2 & 4 \\
\hline Minnesota & 13 & 3 & 2 & 3 & 768 & 2 & 2 & 2 & 1 & 4 \\
\hline New Jersey & 23 & 2 & 7 & 2 & 1 & 879 & 8 & 2 & 6 & 4 \\
\hline New York & 25 & 3 & 6 & 4 & 3 & 10 & 1629 & 4 & 3 & 7 \\
\hline Ohio & 8 & 2 & 2 & 3 & 1 & 2 & 2 & 600 & 3 & 3 \\
\hline Pennsylvania & 13 & 2 & 4 & 1 & 1 & 5 & 4 & 3 & 679 & 3 \\
\hline Texas & 26 & 3 & 5 & 5 & 4 & 5 & 7 & 3 & 3 & 1166 \\
\hline
\end{tabular}

Table 2a: The Effect of Net-of-Tax Rates on Outmigration of Star Scientists: Baseline Models

\begin{tabular}{|c|c|c|c|c|c|c|c|c|}
\hline ATR, 99th Perc. $(1$ - atr $)$ & $\begin{array}{c}(1) \\
2.7805^{* * *} \\
(0.8332)\end{array}$ & $\begin{array}{c}(2) \\
2.0938^{* * *} \\
(0.6324)\end{array}$ & $\begin{array}{c}(3) \\
1.8950^{* * *} \\
(0.6564)\end{array}$ & $\begin{array}{c}(4) \\
1.8046^{* * *} \\
(0.5696)\end{array}$ & $\begin{array}{c}(5) \\
2.0697^{* * *} \\
(0.6527)\end{array}$ & $\begin{array}{c}(6) \\
1.8895^{* * *} \\
(0.6160)\end{array}$ & $\begin{array}{c}(7) \\
0.8027 \\
(0.6499)\end{array}$ & $\begin{array}{c}(8) \\
2.8686^{* * *} \\
(1.0557)\end{array}$ \\
\hline State CIT Rate $(1-$ cit $)$ & $\begin{array}{c}-4.0473^{* * *} \\
(0.9367)\end{array}$ & $\begin{array}{c}1.9865^{* * *} \\
(0.7036)\end{array}$ & $\begin{array}{c}1.8802^{* * *} \\
(0.7037)\end{array}$ & $\begin{array}{l}1.4655^{* *} \\
(0.6081)\end{array}$ & $\begin{array}{c}1.1897 \\
(0.7320)\end{array}$ & $\begin{array}{c}1.9286^{* * *} \\
(0.6615)\end{array}$ & $\begin{array}{c}2.1107^{* * *} \\
(0.6801)\end{array}$ & $\begin{array}{l}1.9095 \\
(1.1785)\end{array}$ \\
\hline State ITC $(1+$ itc $)$ & $\begin{array}{c}5.6643^{* * *} \\
(1.4646)\end{array}$ & $\begin{array}{c}1.8245^{* * *} \\
(0.4683)\end{array}$ & $\begin{array}{c}1.7198^{* * *} \\
(0.5498)\end{array}$ & $\begin{array}{c}1.6948^{* * *} \\
(0.5674)\end{array}$ & $\begin{array}{c}1.8006^{* * *} \\
(0.5079)\end{array}$ & $\begin{array}{c}1.7253^{* * *} \\
(0.5825)\end{array}$ & $\begin{array}{c}2.2891^{* * *} \\
(0.7705)\end{array}$ & $\begin{array}{l}1.5642^{* *} \\
(0.7760)\end{array}$ \\
\hline R\&D Credit $(1+$ cred $)$ & $\begin{array}{c}3.3101^{* * *} \\
(0.7070)\end{array}$ & $\begin{array}{l}0.3428^{*} \\
(0.2021)\end{array}$ & $\begin{array}{l}0.3621^{*} \\
(0.2196) \\
\end{array}$ & $\begin{array}{l}-0.0349 \\
(0.2179)\end{array}$ & $\begin{array}{c}0.0734 \\
(0.2117) \\
\end{array}$ & $\begin{array}{l}0.3978^{*} \\
(0.2301)\end{array}$ & $\begin{array}{c}1.0309^{* * *} \\
(0.2869) \\
\end{array}$ & $\begin{array}{l}-0.4218 \\
(0.3335) \\
\end{array}$ \\
\hline Origin, Destination State FE & No & Yes & No & No & No & No & No & No \\
\hline Origin*Destination Pair FE & No & No & Yes & Yes & Yes & Yes & Yes & Yes \\
\hline Origin Region*Year FE & No & No & No & Yes & No & No & No & No \\
\hline Destination Region*Year FE & No & No & No & No & Yes & No & No & No \\
\hline $\begin{array}{l}\text { Origin \& Destination Pair } \\
\text { Region*Year FE }\end{array}$ & No & No & No & No & No & Yes & No & No \\
\hline Origin State*Year FE & No & No & No & No & No & No & Yes & No \\
\hline Destination State*Year FE & No & No & No & No & No & No & No & Yes \\
\hline
\end{tabular}

Table 2b: Alternative Measure of ATR

\begin{tabular}{|c|c|c|c|c|c|c|c|c|}
\hline ATR, 99th Perc. $(1$ - atr $)$ & $\begin{array}{c}(1) \\
0.5966 \\
(0.5035)\end{array}$ & $\begin{array}{c}(2) \\
1.4434^{* * *} \\
(0.3450)\end{array}$ & $\begin{array}{c}(3) \\
1.4474^{* * *} \\
(0.3551)\end{array}$ & $\begin{array}{c}(4) \\
1.3798^{* * *} \\
(0.3013)\end{array}$ & $\begin{array}{c}(5) \\
1.4695^{* * *} \\
(0.3565)\end{array}$ & $\begin{array}{c}(6) \\
1.4587^{* * *} \\
(0.3360)\end{array}$ & $\begin{array}{c}(7) \\
0.9918^{* * *} \\
(0.3377)\end{array}$ & $\begin{array}{c}(8) \\
1.9562^{* * *} \\
(0.5574)\end{array}$ \\
\hline State CIT Rate (1 - cit) & $\begin{array}{c}-3.3335^{* * *} \\
(0.9443)\end{array}$ & $\begin{array}{l}1.7035^{* *} \\
(0.7062)\end{array}$ & $\begin{array}{l}1.6012^{* *} \\
(0.7007)\end{array}$ & $\begin{array}{l}1.2030^{* *} \\
(0.5957)\end{array}$ & $\begin{array}{c}0.9290 \\
(0.7316)\end{array}$ & $\begin{array}{l}1.6459^{* *} \\
(0.6564)\end{array}$ & $\begin{array}{c}1.8578^{* * *} \\
(0.6545)\end{array}$ & $\begin{array}{l}1.5620 \\
(1.1861)\end{array}$ \\
\hline State ITC $(1+$ itc $)$ & $\begin{array}{l}5.0209^{* * *} \\
(1.4752)\end{array}$ & $\begin{array}{c}1.9334^{* * * *} \\
(0.4695)\end{array}$ & $\begin{array}{c}1.8381^{* * *} \\
(0.5502)\end{array}$ & $\begin{array}{c}1.7932^{* * *} \\
(0.5646)\end{array}$ & $\begin{array}{c}1.8935^{* * *} \\
(0.5069)\end{array}$ & $\begin{array}{c}1.8461^{* * *} \\
(0.5818)\end{array}$ & $\begin{array}{c}2.4058^{* * *} \\
(0.7655)\end{array}$ & $\begin{array}{l}1.7122^{* *} \\
(0.7760)\end{array}$ \\
\hline R\&D Credit $(1+$ cred $)$ & $\begin{array}{c}3.1642^{* * *} \\
(0.6996)\end{array}$ & $\begin{array}{c}0.2917 \\
(0.2019)\end{array}$ & $\begin{array}{c}0.3100 \\
(0.2201)\end{array}$ & $\begin{array}{l}-0.0772 \\
(0.2188)\end{array}$ & $\begin{array}{c}0.0280 \\
(0.2117)\end{array}$ & $\begin{array}{c}0.3454 \\
(0.2307)\end{array}$ & $\begin{array}{c}1.0008^{* * *} \\
(0.2894)\end{array}$ & $\begin{array}{l}-0.4843 \\
(0.3309)\end{array}$ \\
\hline Origin, Destination State FE & No & Yes & No & No & No & No & No & No \\
\hline Origin*Destination Pair FE & No & No & Yes & Yes & Yes & Yes & Yes & Yes \\
\hline Origin Region*Year FE & No & No & No & Yes & No & No & No & No \\
\hline Destination Region*Year FE & No & No & No & No & Yes & No & No & No \\
\hline $\begin{array}{l}\text { Origin \& Destination Pair } \\
\text { Region*Year FE }\end{array}$ & No & No & No & No & No & Yes & No & No \\
\hline Origin State*Year FE & No & No & No & No & No & No & Yes & No \\
\hline Destination State*Year FE & No & No & No & No & No & No & No & Yes \\
\hline
\end{tabular}


Table 3: Asymmetric Effects for Origin and Destination Taxes

\begin{tabular}{|c|c|c|}
\hline & (1) & $(2)$ \\
\hline ATR, 99th Perc., Origin (1 - atr) & $\begin{array}{c}-2.9871^{* * *} \\
(1.0713)\end{array}$ & $\begin{array}{c}-2.7239^{* * *} \\
(0.9911)\end{array}$ \\
\hline ATR, 99th Perc., Dest. (1 - atr) & $\begin{array}{c}0.7397 \\
(0.7744)\end{array}$ & $\begin{array}{c}1.0213 \\
(0.8295)\end{array}$ \\
\hline State CIT Rate, Origin (1 - cit) & $\begin{array}{l}-2.0873^{*} \\
(1.1889)\end{array}$ & $\begin{array}{c}-2.2472^{* *} \\
(1.1031)\end{array}$ \\
\hline State CIT Rate, Dest. (1 - cit) & $\begin{array}{c}1.6249^{* *} \\
(0.7994)\end{array}$ & $\begin{array}{l}1.5514^{*} \\
(0.7970)\end{array}$ \\
\hline State ITC, Origin $(1+$ itc $)$ & $\begin{array}{c}-1.5895^{* *} \\
(0.7702)\end{array}$ & $\begin{array}{c}-1.4324^{* *} \\
(0.7235)\end{array}$ \\
\hline State ITC, Dest. $(1+$ itc $)$ & $\begin{array}{l}1.8690^{* *} \\
(0.7423)\end{array}$ & $\begin{array}{l}2.0410^{* *} \\
(0.8580)\end{array}$ \\
\hline 111R\&D Credit, Origin $(1+$ cred $)$ & $\begin{array}{c}0.2483 \\
(0.3337)\end{array}$ & $\begin{array}{c}0.4130 \\
(0.3279)\end{array}$ \\
\hline R\&D Credit, Dest. $(1+$ cred $)$ & $\begin{array}{c}0.9543^{* * *} \\
(0.3023)\end{array}$ & $\begin{array}{c}1.1913^{* * *} \\
(0.3404)\end{array}$ \\
\hline Origin*Destination Pair FE & Yes & Yes \\
\hline $\begin{array}{l}\text { Origin \& Destination Pair } \\
\text { Region*Year FE }\end{array}$ & No & Yes \\
\hline
\end{tabular}

Table 4: Estimates for Cells with Small Number of Movers

\begin{tabular}{|c|c|c|c|c|c|c|c|}
\hline & $\begin{array}{c}(1) \\
\# \text { of movers } \\
\text { in cell = all }\end{array}$ & $\begin{array}{c}(2) \\
\# \text { of movers } \\
\text { in cell }=1\end{array}$ & $\begin{array}{c}(3) \\
\# \text { of movers } \\
\text { in cell } \leq 2\end{array}$ & $\begin{array}{c}(4) \\
\# \text { of movers } \\
\text { in cell } \leq 3\end{array}$ & $\begin{array}{c}(5) \\
\# \text { of movers } \\
\text { in cell } \leq 4\end{array}$ & $\begin{array}{c}(6) \\
\# \text { of movers } \\
\text { in cell } \leq 7\end{array}$ & $\begin{array}{c}(7) \\
\# \text { of movers } \\
\text { in cell } \leq 10\end{array}$ \\
\hline ATR, 99th Perc. $(1-$ atr $)$ & $\begin{array}{c}1.8895^{* * *} \\
(0.6160)\end{array}$ & $\begin{array}{c}1.9154^{* * *} \\
(0.5545)\end{array}$ & $\begin{array}{c}1.9030^{* * *} \\
(0.5840)\end{array}$ & $\begin{array}{c}2.2173^{* * *} \\
(0.5746)\end{array}$ & $\begin{array}{c}2.0132^{* * *} \\
(0.5679)\end{array}$ & $\begin{array}{c}2.0073^{* * *} \\
(0.5737)\end{array}$ & $\begin{array}{c}2.0396^{* * *} \\
(0.5914)\end{array}$ \\
\hline State CIT Rate (1 - cit) & $\begin{array}{c}1.9286^{* * *} \\
(0.6615)\end{array}$ & $\begin{array}{c}2.1043^{* * *} \\
(0.6687)\end{array}$ & $\begin{array}{c}2.1033^{* * *} \\
(0.6659)\end{array}$ & $\begin{array}{c}1.7877^{* * *} \\
(0.6372)\end{array}$ & $\begin{array}{c}2.0505^{* * *} \\
(0.6410)\end{array}$ & $\begin{array}{c}1.8644^{* * *} \\
(0.6341)\end{array}$ & $\begin{array}{c}1.8995^{* * *} \\
(0.6484)\end{array}$ \\
\hline State ITC $(1+$ itc $)$ & $\begin{array}{c}1.7253^{* * *} \\
(0.5825)\end{array}$ & $\begin{array}{l}0.8551^{*} \\
(0.4439)\end{array}$ & $\begin{array}{c}1.3433^{* * *} \\
(0.4360)\end{array}$ & $\begin{array}{c}1.4210^{* * *} \\
(0.4308)\end{array}$ & $\begin{array}{c}1.4016^{* * *} \\
(0.4637)\end{array}$ & $\begin{array}{c}1.3639^{* * *} \\
(0.4602)\end{array}$ & $\begin{array}{c}1.5133^{* * *} \\
(0.4803)\end{array}$ \\
\hline R\&D Credit $(1+$ cred $)$ & $\begin{array}{c}0.3978^{*} \\
(0.2301)\end{array}$ & $\begin{array}{c}0.2283 \\
(0.1889)\end{array}$ & $\begin{array}{c}0.2171 \\
(0.1872)\end{array}$ & $\begin{array}{c}0.2993 \\
(0.1851)\end{array}$ & $\begin{array}{l}0.3695^{*} \\
(0.1919)\end{array}$ & $\begin{array}{l}0.3512^{*} \\
(0.1927)\end{array}$ & $\begin{array}{l}0.3578^{*} \\
(0.1978)\end{array}$ \\
\hline No. Observations & 15247 & 9085 & 12012 & 13318 & 14372 & 14756 & 14974 \\
\hline $\begin{array}{l}\text { Origin*Destination Pair FE } \\
\text { Origin \& Destination Pair }\end{array}$ & Yes & Yes & Yes & Yes & Yes & Yes & Yes \\
\hline Region*Year FE & Yes & Yes & Yes & Yes & Yes & Yes & Yes \\
\hline
\end{tabular}


Table 5: Effect of Payroll Apportionment Formula Weight on Sensitivity to Corporate Tax

\begin{tabular}{|c|c|c|}
\hline State CIT Rate - Origin & $\begin{array}{c}(1) \\
-1.8507 \\
(1.3103)\end{array}$ & $\begin{array}{c}(2) \\
-1.1985 \\
(1.2828)\end{array}$ \\
\hline State CIT Rate - Destination & $\begin{array}{c}0.4892 \\
(0.8544)\end{array}$ & $\begin{array}{c}0.2877 \\
(0.8759)\end{array}$ \\
\hline Payroll Dummy*State CIT Rate- Origin & $\begin{array}{c}-0.9667 \\
(0.9382)\end{array}$ & $\begin{array}{c}-1.5664^{*} \\
(0.9009)\end{array}$ \\
\hline Payroll Dummy*State CIT Rate- Destination & $\begin{array}{c}2.9753^{* * *} \\
(0.9196)\end{array}$ & $\begin{array}{c}2.6523^{* * *} \\
(0.8438)\end{array}$ \\
\hline Payroll Dummy- Origin & $\begin{array}{c}-0.1516^{* *} \\
(0.0765)\end{array}$ & $\begin{array}{c}-1.5664^{*} \\
(0.9009)\end{array}$ \\
\hline Payroll Dummy- Destination & $\begin{array}{c}0.1871^{* *} \\
(0.0737)\end{array}$ & $\begin{array}{c}2.6523^{* * *} \\
(0.8438)\end{array}$ \\
\hline ATR, 99th Perc. Origin & & $\begin{array}{c}-0.1935^{* * *} \\
(0.0746)\end{array}$ \\
\hline ATR, 99th Perc. Destination & & $\begin{array}{c}0.1800^{* *} \\
(0.0707)\end{array}$ \\
\hline State ITC - Origin & & $\begin{array}{c}-2.8435^{* * *} \\
(1.0775)\end{array}$ \\
\hline State ITC - Destination & & $\begin{array}{c}1.1845 \\
(0.7414)\end{array}$ \\
\hline R\&D Credit - Origin & & $\begin{array}{c}-1.8352^{* *} \\
(0.7804)\end{array}$ \\
\hline R\&D Credit - Destination & & $\begin{array}{c}0.6772^{* *} \\
(0.2724) \\
\end{array}$ \\
\hline Implied Origin CIT Effect when Dummy $=1$ & $\begin{array}{c}-2.8175^{* *} \\
(1.2780)\end{array}$ & $\begin{array}{c}-2.7649^{* *} \\
(1.2095)\end{array}$ \\
\hline Implied Destination CIT Effect when Dummy $=1$ & $\begin{array}{c}3.4644^{* * *} \\
(.9398) \\
\end{array}$ & $\begin{array}{c}2.9400^{* * *} \\
(.8838)\end{array}$ \\
\hline Origin*Destination Pair FE & Yes & Yes \\
\hline \multicolumn{3}{|l|}{ Origin \& Destination Pair } \\
\hline Region*Year FE & Yes & Yes \\
\hline $\begin{array}{l}\text { Notes: Each column is from a separate regression. Pay } \\
\text { apportionment formula puts positive weight on firm } \\
\text { parentheses, with three-way clustering by origin-state } \\
\text { and state-pair. Implied Origin CIT effect is the sum o } \\
\text { and 3. Implied Destination CIT effect is the sum of th } \\
\text { All regressions include year fixed effects, and have } 152 \\
{ }^{*} p<0.10,{ }^{* *} p<0.05,{ }^{* * *} p<0.01\end{array}$ & $\begin{array}{l}\text { oll dummy } \\
\text { roll. Standi } \\
\text { ear, destina } \\
\text { the coefficie } \\
\text { coefficients } \\
7 \text { observatio }\end{array}$ & $\begin{array}{l}1 \text { if state } \\
\text { errors in } \\
\text { n-state*year, } \\
\text { in row } 1 \\
\text { row } 2 \text { and } 4 .\end{array}$ \\
\hline
\end{tabular}


Table 6: The Effects of Net-of-Tax Rates on Outmigration of Star Scientists: Selected Subsamples

\begin{tabular}{|c|c|c|c|c|}
\hline & $\begin{array}{c}(1) \\
\text { Baseline }\end{array}$ & $\begin{array}{c}(2) \\
\text { Corporate Scientists }\end{array}$ & Academic \& Gov't Scientists & $\begin{array}{c}(4) \\
\text { Individual Inventors }\end{array}$ \\
\hline Average Tax Rate & $\begin{array}{c}1.8895^{* * *} \\
(0.6160)\end{array}$ & $\begin{array}{c}2.4348^{* * *} \\
(0.6825)\end{array}$ & $\begin{array}{c}0.4544 \\
(1.6091)\end{array}$ & $\begin{array}{l}-0.9877 \\
(0.6359)\end{array}$ \\
\hline State CIT Rate & $\begin{array}{c}1.9286^{* * *} \\
(0.6615)\end{array}$ & $\begin{array}{c}1.9803^{* * *} \\
(0.7520)\end{array}$ & $\begin{array}{c}0.1109 \\
(1.5054)\end{array}$ & $\begin{array}{l}-0.4956 \\
(0.9013)\end{array}$ \\
\hline State ITC & $\begin{array}{c}1.7253^{* * *} \\
(0.5825)\end{array}$ & $\begin{array}{c}1.8127^{* * *} \\
(0.6554)\end{array}$ & $\begin{array}{l}-0.7212 \\
(0.7883)\end{array}$ & $\begin{array}{l}1.4812^{* *} \\
(0.6499)\end{array}$ \\
\hline R\&D Credit & $\begin{array}{l}0.3978^{*} \\
(0.2301) \\
\end{array}$ & $\begin{array}{c}0.3843 \\
(0.2518) \\
\end{array}$ & $\begin{array}{l}0.8454^{* *} \\
(0.3679) \\
\end{array}$ & $\begin{array}{c}0.8625^{* * *} \\
(0.2575) \\
\end{array}$ \\
\hline No. Observations & 15247 & 12564 & 2011 & 4081 \\
\hline $\begin{array}{l}\text { Origin*Destination Pair FE } \\
\text { Origin \& Destination Pair }\end{array}$ & Yes & Yes & Yes & Yes \\
\hline Region*Year FE & Yes & Yes & Yes & Yes \\
\hline
\end{tabular}

Table 7: Models that Include Property and Sales Taxes

\begin{tabular}{|c|c|c|c|c|c|c|}
\hline ATR, 99th Perc. $(1$ - atr) & $\begin{array}{c}(1) \\
1.8895^{* * *} \\
(0.6160)\end{array}$ & $\begin{array}{c}(2) \\
1.3781^{* *} \\
(0.6177)\end{array}$ & $\begin{array}{c}(3) \\
1.6622^{* * *} \\
(0.6092)\end{array}$ & $\begin{array}{c}(4) \\
1.1529^{*} \\
(0.6185)\end{array}$ & $\begin{array}{c}(5) \\
1.3952^{* *} \\
(0.6178)\end{array}$ & $(6)$ \\
\hline State CIT Rate (1 - cit) & $\begin{array}{c}1.9286^{* * *} \\
(0.6615)\end{array}$ & $\begin{array}{c}2.0307^{* * *} \\
(0.6547)\end{array}$ & $\begin{array}{c}2.3595^{* * *} \\
(0.6923)\end{array}$ & $\begin{array}{c}2.4734^{* * *} \\
(0.6923)\end{array}$ & $\begin{array}{c}2.0086^{* * *} \\
(0.6544)\end{array}$ & $\begin{array}{c}2.1962^{* * *} \\
(0.6559)\end{array}$ \\
\hline State ITC $(1+$ itc $)$ & $\begin{array}{c}1.7253^{* * *} \\
(0.5825)\end{array}$ & $\begin{array}{c}1.5286^{* * *} \\
(0.5697)\end{array}$ & $\begin{array}{c}1.6293^{* * *} \\
(0.5680)\end{array}$ & $\begin{array}{c}1.4537^{* * *} \\
(0.5572)\end{array}$ & $\begin{array}{c}1.5317^{* * *} \\
(0.5703)\end{array}$ & $\begin{array}{c}1.4903^{* * *} \\
(0.5629)\end{array}$ \\
\hline R\&D Credit $(1+$ cred $)$ & $\begin{array}{l}0.3978^{*} \\
(0.2301)\end{array}$ & $\begin{array}{l}0.3983^{*} \\
(0.2309)\end{array}$ & $\begin{array}{c}0.3674 \\
(0.2250)\end{array}$ & $\begin{array}{c}0.3633 \\
(0.2254)\end{array}$ & $\begin{array}{l}0.4001^{*} \\
(0.2311)\end{array}$ & $\begin{array}{l}0.4152^{*} \\
(0.2307)\end{array}$ \\
\hline Prop tax revenues/income $(1-\mathrm{ptshr})$ & & $\begin{array}{c}0.5586^{* * *} \\
(0.1489)\end{array}$ & & $\begin{array}{c}0.5653^{* * *} \\
(0.1486)\end{array}$ & & \\
\hline Sales tax rate $(1-$ str $)$ & & & $\begin{array}{c}-3.1153^{* *} \\
(1.2743)\end{array}$ & $\begin{array}{c}-3.2259^{* *} \\
(1.2863)\end{array}$ & & \\
\hline Effective consumption tax rate $(1-$ ectr $)$ & & & & & $\begin{array}{c}0.5398^{* * *} \\
(0.1463)\end{array}$ & \\
\hline Effective personal tax rate $(1-$ eptr $)$ & & & & & & $\begin{array}{c}0.2933^{* * *} \\
(0.0716)\end{array}$ \\
\hline Origin*Destination Pair FE & Yes & Yes & Yes & Yes & Yes & Yes \\
\hline $\begin{array}{l}\text { Origin \& Destination Pair } \\
\text { Region*Year FE }\end{array}$ & Yes & Yes & Yes & Yes & Yes & Yes \\
\hline
\end{tabular}




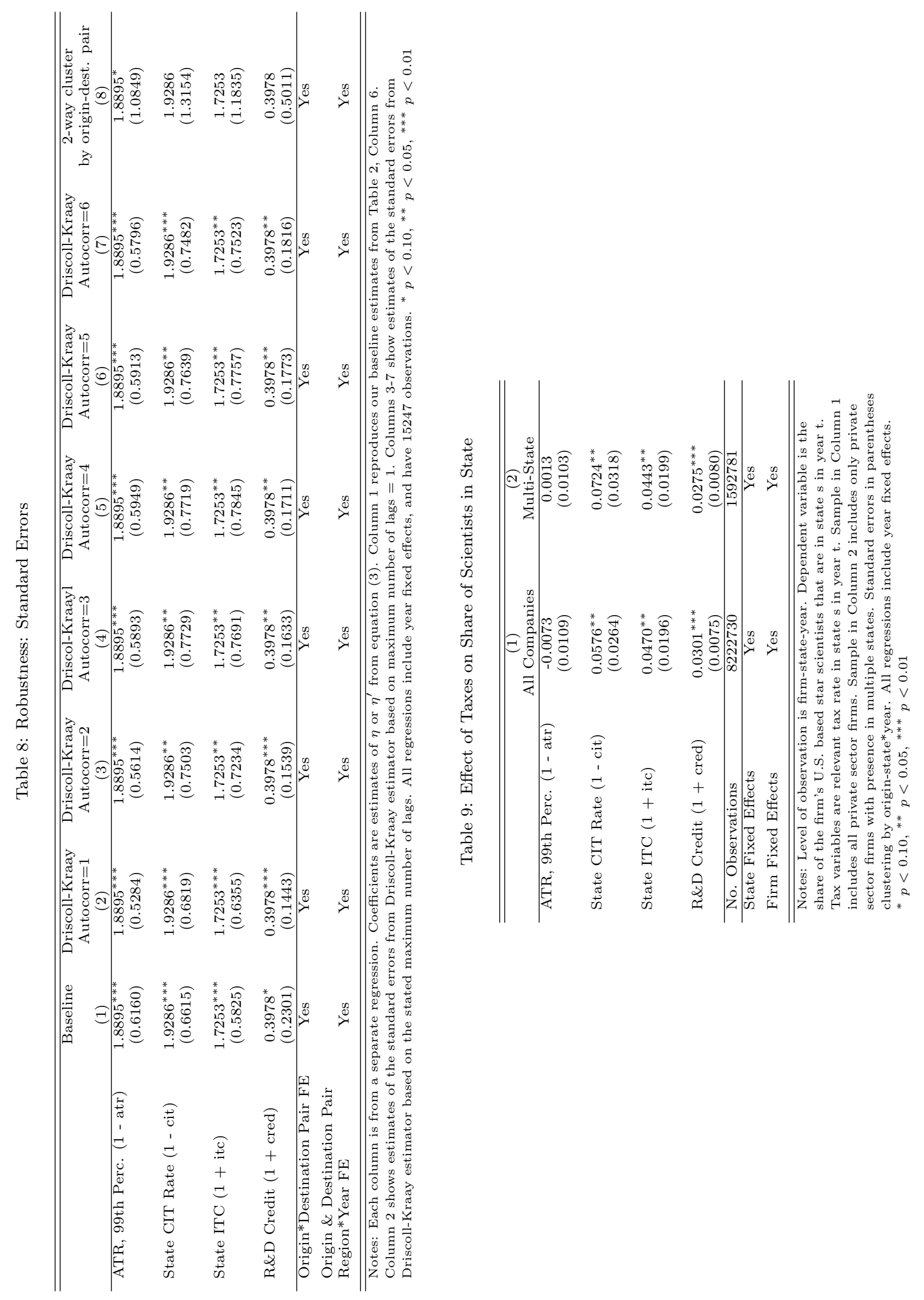


Figure 1

State Average Tax Rate at 99th Income Percentile - 2010

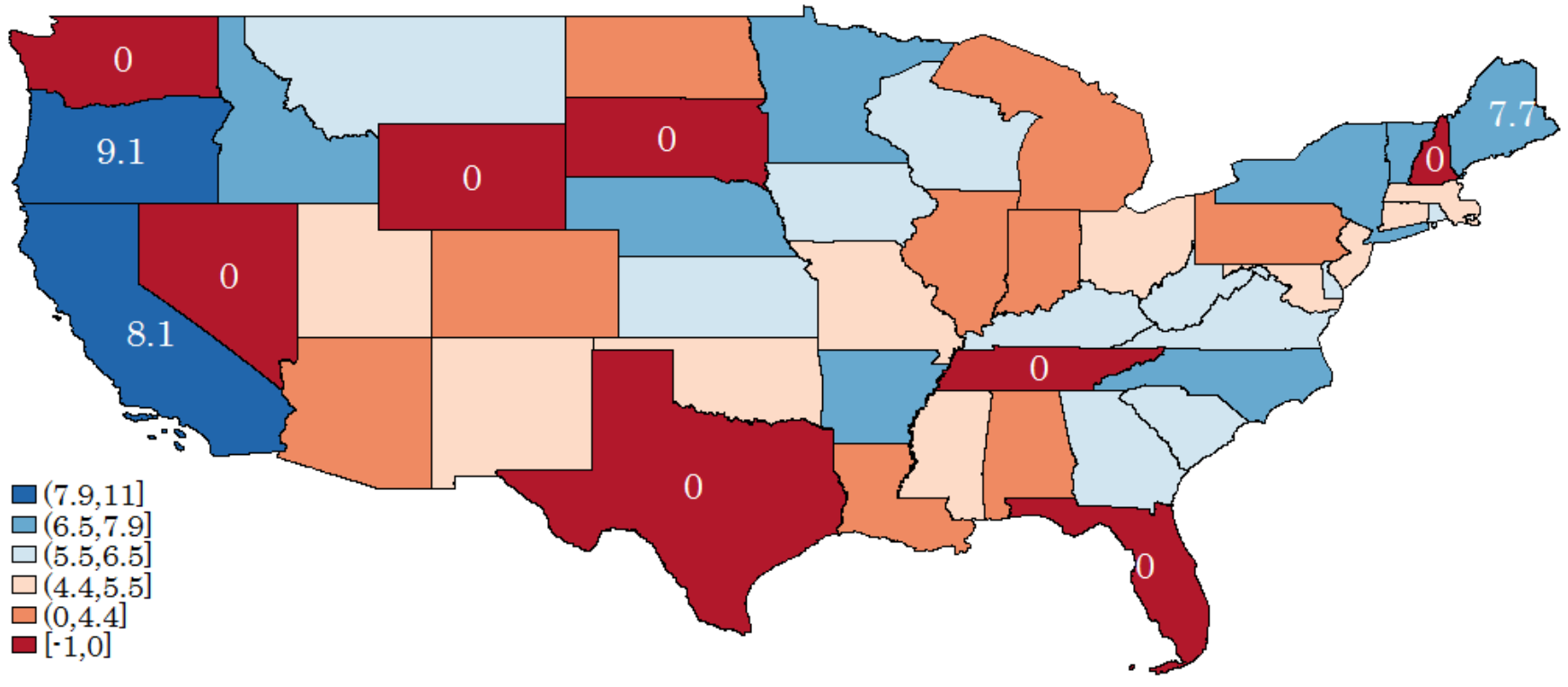

Figure 2

Average Tax Rate - Corporate Income, 2010

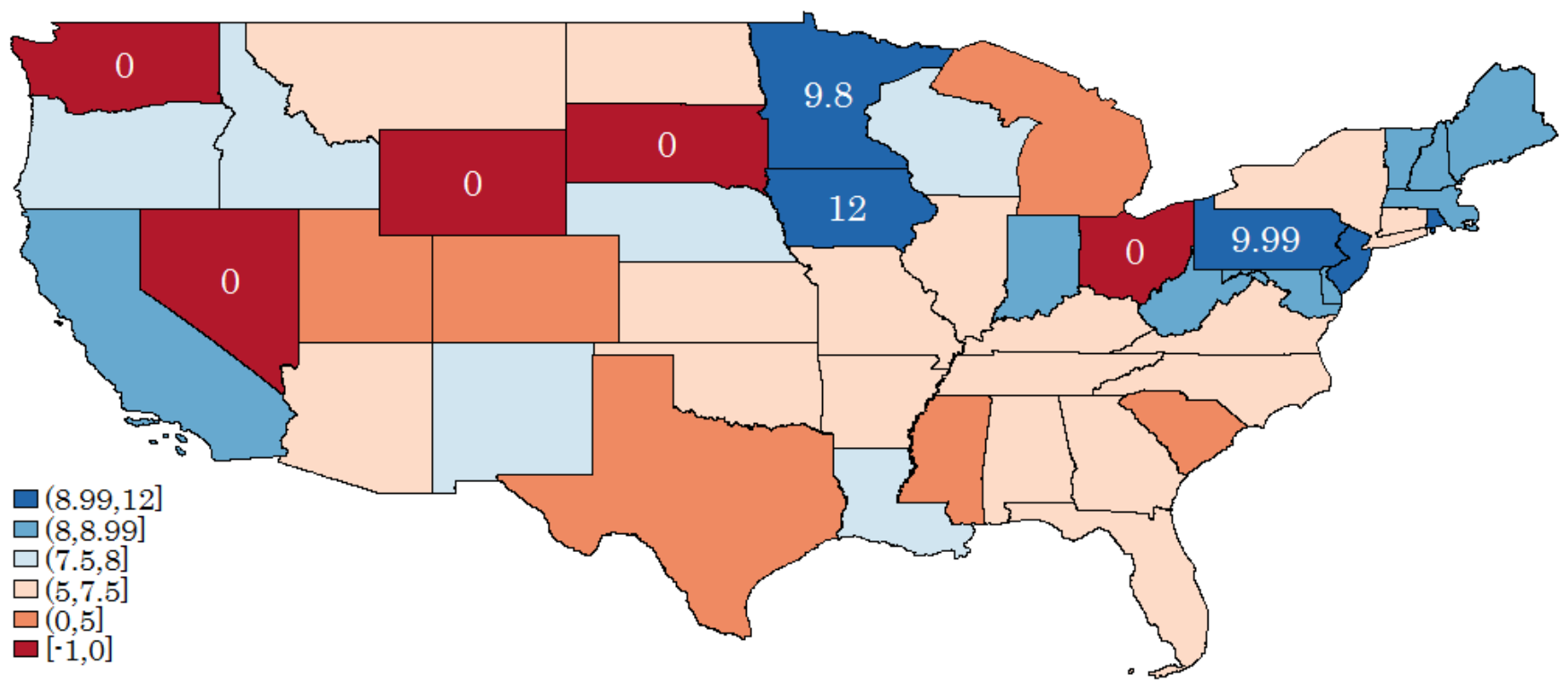




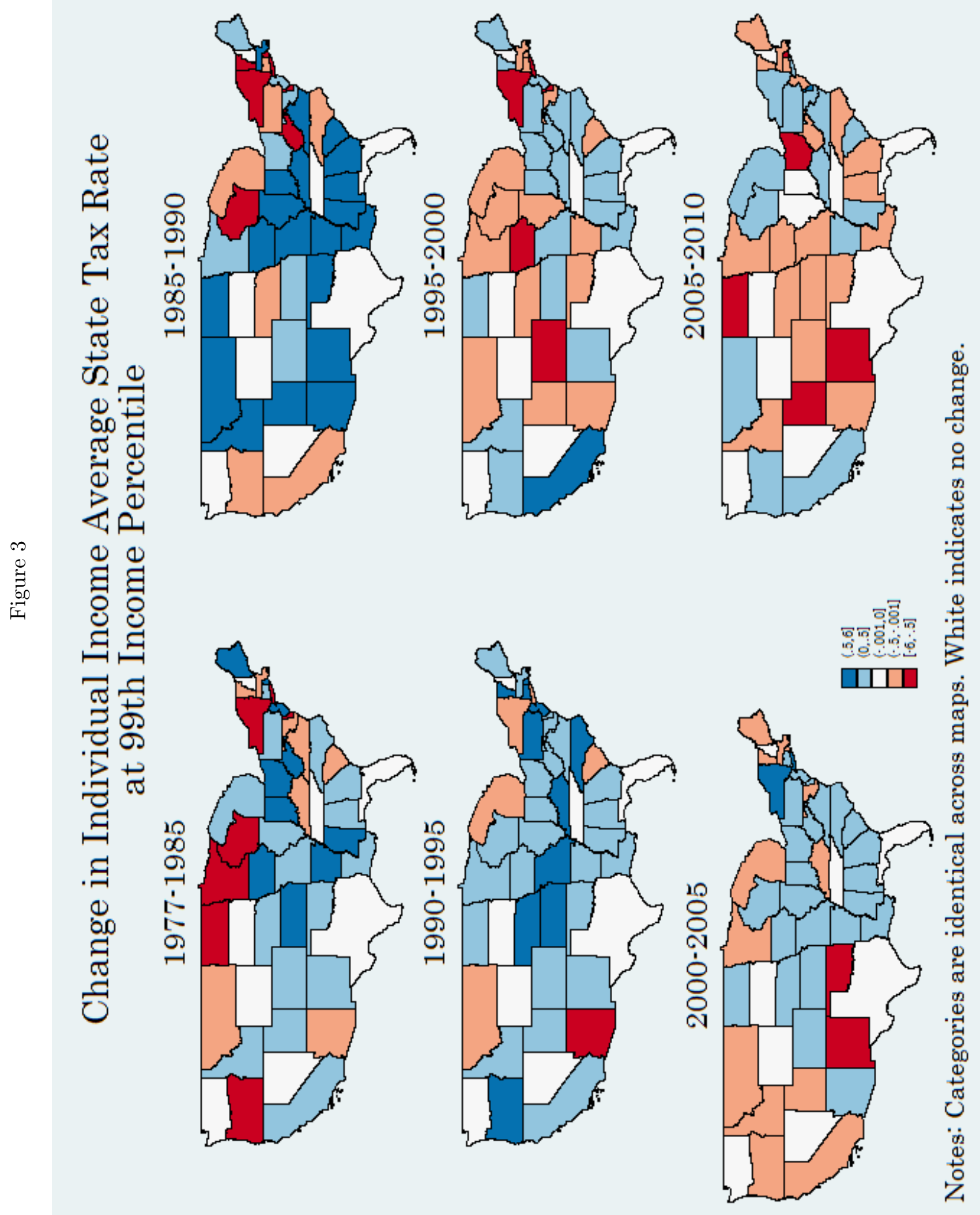




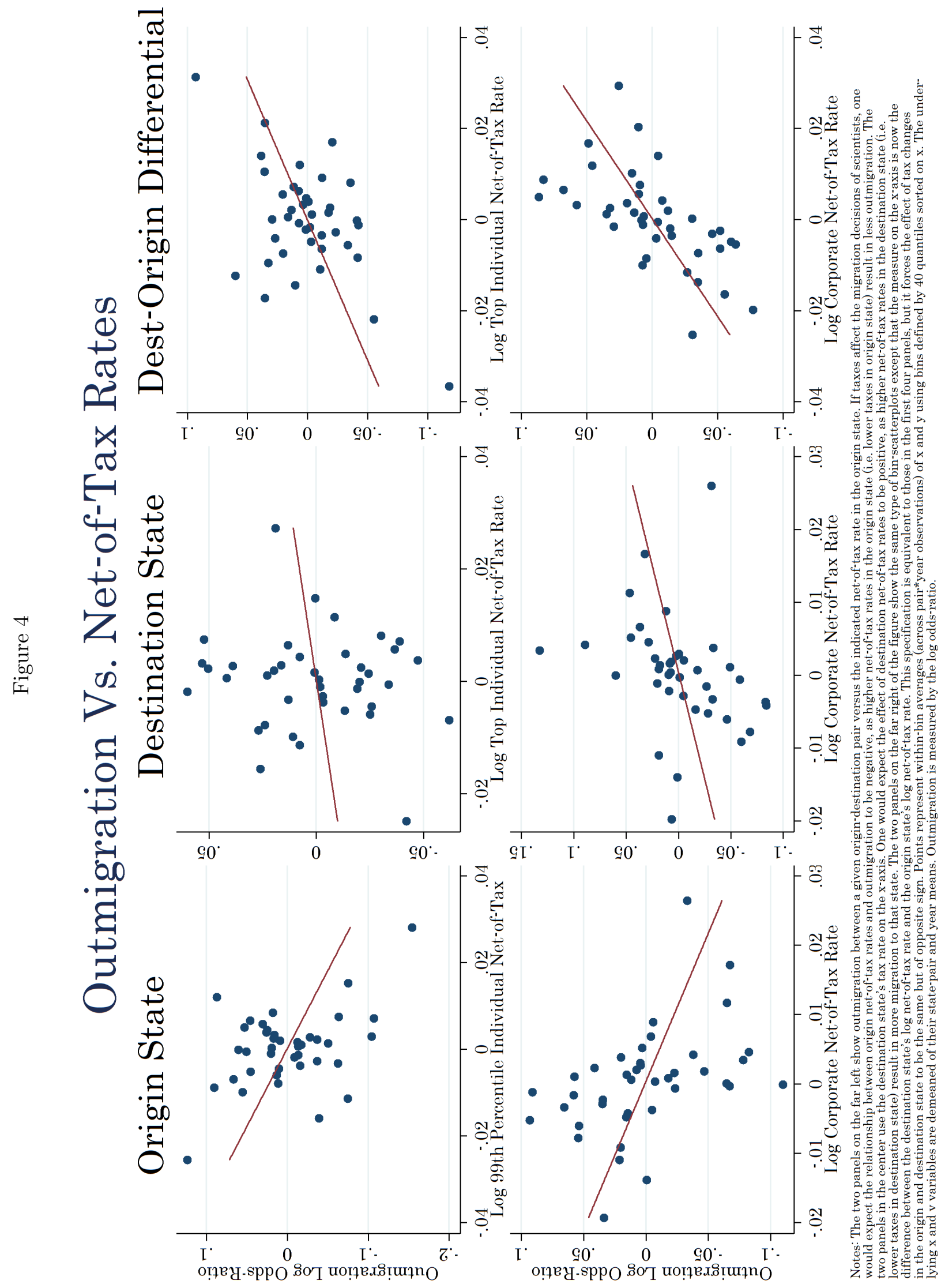



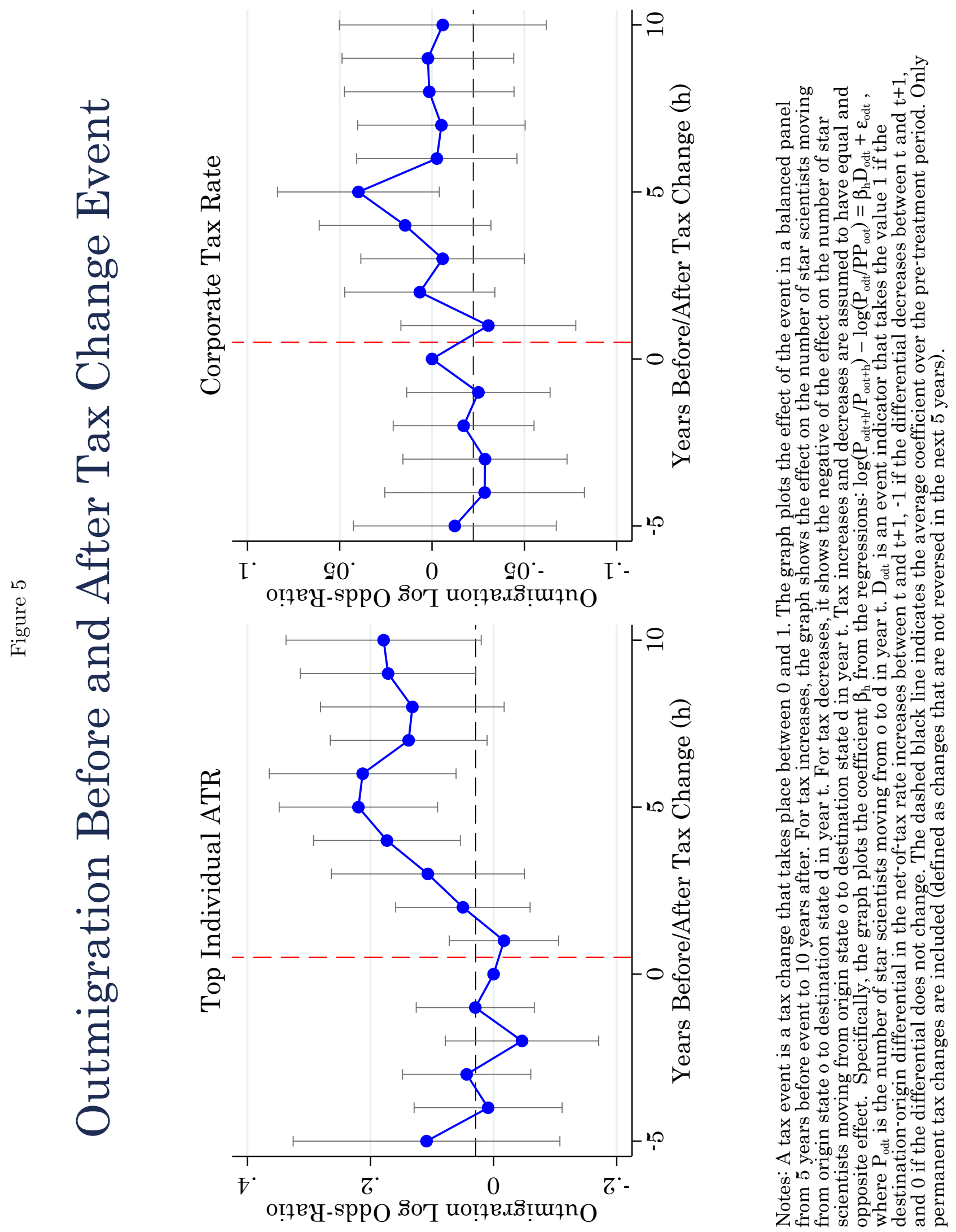
Figure 6. Impulse Response Functions

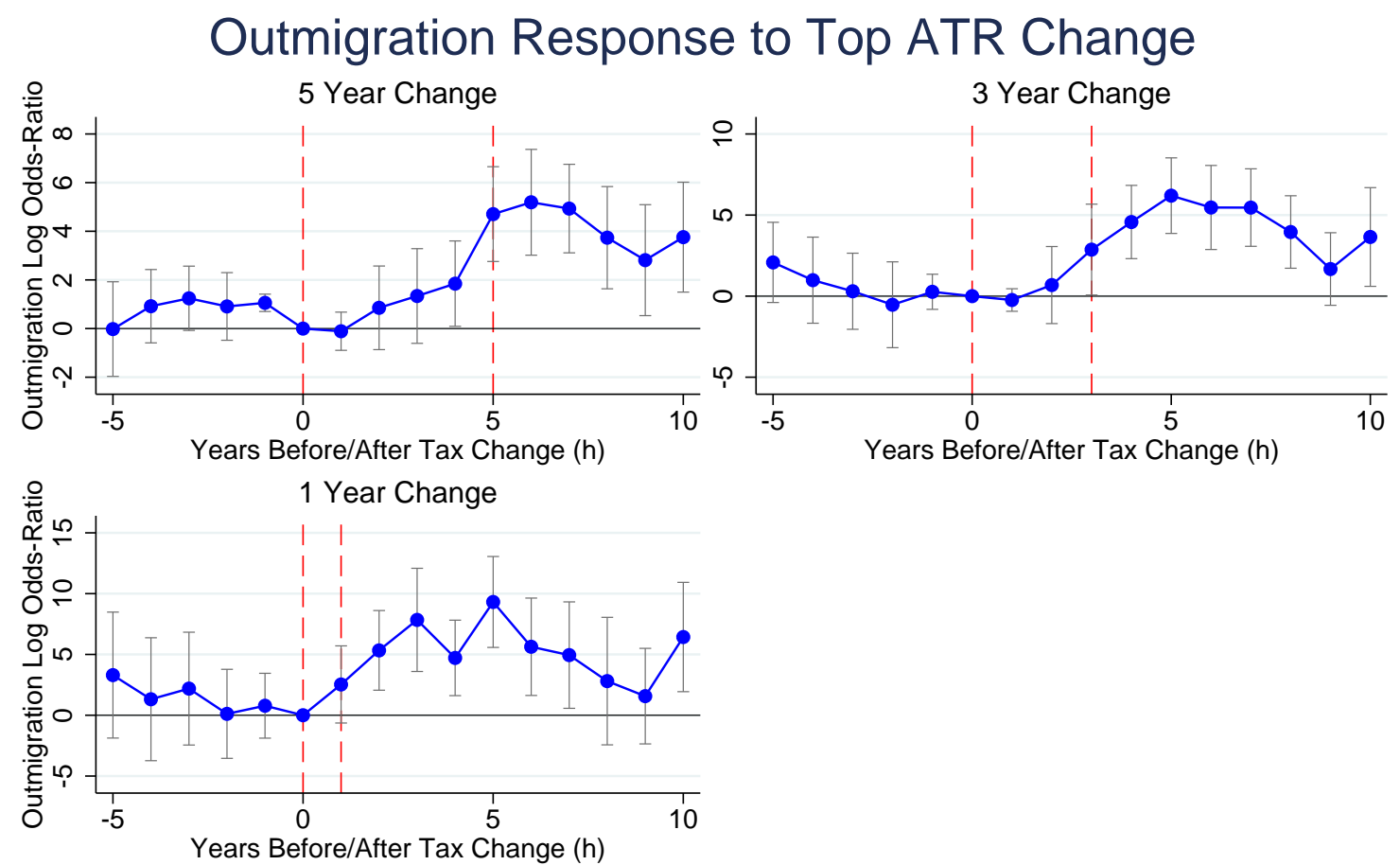

Notes: All regressions use the same sample, a balanced panel from 5 years before event to 10 years after. Graph plots ${ }^{n}$ from regression: $\ln P_{\text {odt }}$ in $\ln P_{\text {odt }}={ }^{h}\left(n_{\text {odt }+x} \quad n_{\text {odt }}\right)+F_{\text {odt }}+$ odt where $\ln P$ is the log odds-ratio of outmigration and $\mathrm{n}_{\text {odt }}$ is the destination-origin differential in the net-of-tax rate in year $t$, and $x$ is 1,3 , or 5 . $F_{\text {odt }}$ is a year fixed effect specific to the region(o) ${ }^{\star}$ region(d) pair.

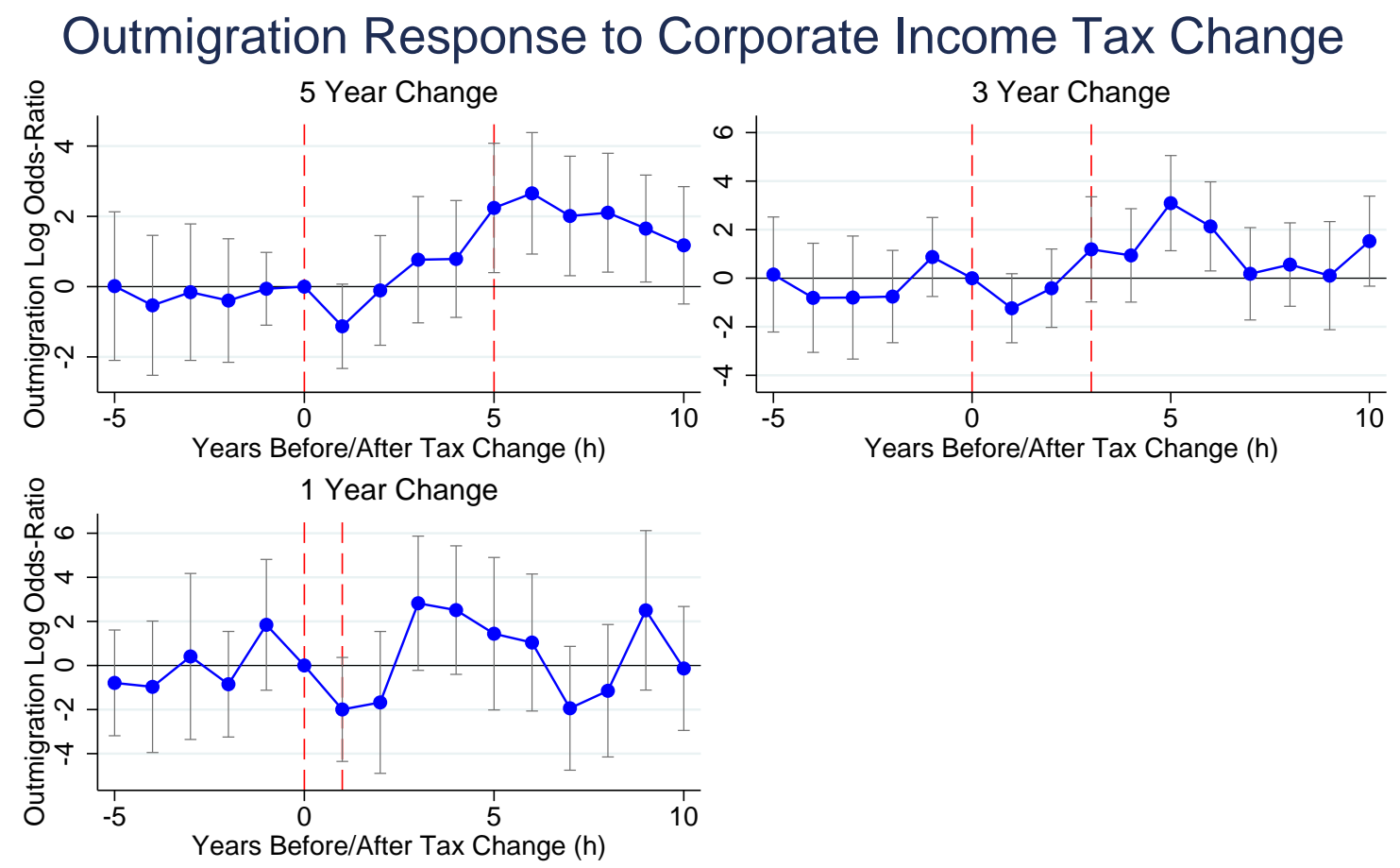

Notes: All regressions use the same sample, a balanced panel from 5 years before event to 10 years after. Graph plots ${ }^{n}$ from regression: $\operatorname{In} P_{\text {odth }} \ln P_{\text {odt }}={ }_{h}\left(n_{\text {odt }} \quad n_{\text {odt }}\right)+F_{\text {odt }}+$ odt, where $\ln P$ is the log odds-ratio of outmigration and $\mathrm{n}_{\text {odt }}$ is the destination-origin differential in the net-of-tax rate in year $t$, and $x$ is 1,3 , or 5 . $F_{\text {odt }}$ is a year fixed effect specific to the region(o) ${ }^{*}$ region(d) pair. 
Figure 7

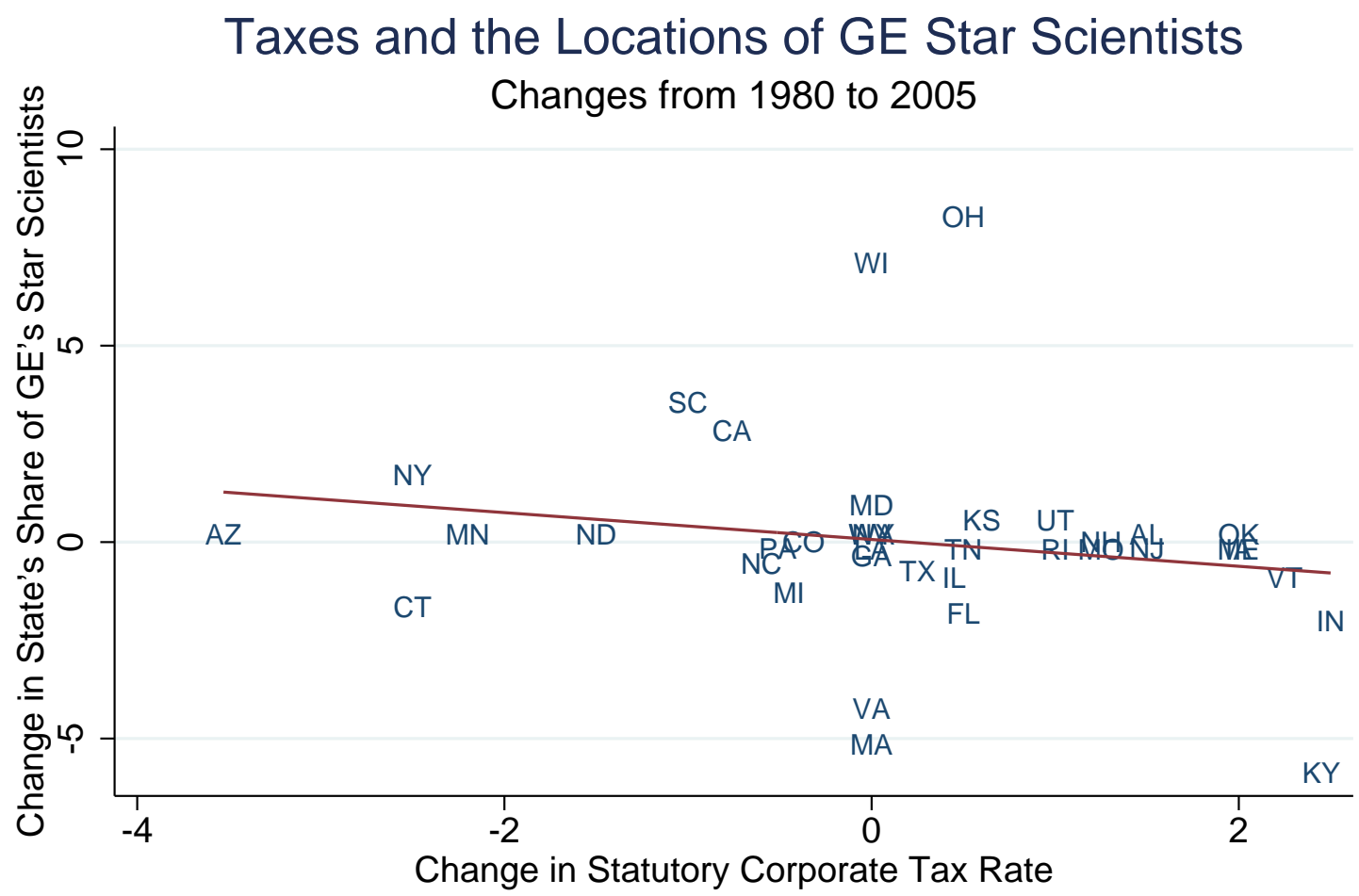

Excluding states with fewer than two GE star scientists in both 1980 and 2005. Changes are in percentage points. 


\title{
The Effect of State Taxes on the Geographical Location of Top Earners: Evidence from Star Scientists
}

\author{
By ENRICO MORETTI AND DANIEL J. WiLSON
}

\section{Online Appendix}

In Section 2.2, we described the general construction of our tax variables. Here we provide further detail.

We obtain business tax and credit rates by state and year for corporate income taxes, investment tax credits, and research and development tax credits from Chirinko \& Wilson (2008), Wilson (2009), and Moretti \& Wilson (2014). We use the "effective" state corporate income tax rate, which adjusts the statutory tax rate for deductibility of state taxes on federal corporate tax returns and, in some states, vice versa. It is a function of the state statutory tax rate, the federal statutory tax rate, and the share of federal taxes that are deductible from state corporate income for each state. (See Chirinko \& Wilson 2008 for further details.)

To construct the average and marginal individual income tax rates for a hypothetical taxpayer, at a specified income level, in each state and year, we used the National Bureau of Economic Research (NBER) Internet TaxSim calculator. We first obtained data, for each year from 1977 to 2010 , on the $95^{\text {th }}, 99^{\text {th }}$, and $99.9^{\text {th }}$ percentiles of the national income distribution (separately for salary and capital gains) from the World Top Incomes Database (Alvaredo, Atkinson, Piketty \& Saez 2013) and data on the $50^{\text {th }}$ percentile from the Congressional Budget Office (CBO). These nominal income levels then became inputs - as primary wage earnings and long-term capital gains - into the NBER's Internet TaxSim calculator. Other inputs were the following assumptions: The taxpayer was a married joint filer, less than 65 years old, had zero dependent exemptions, zero childcare expenses, no other sources of income, and zero itemized deductions other than the deduction for state income tax payments (which is calculated by TaxSim). In other words, aside from primary wage earnings and long-term capital gains, all other inputs into TaxSim were 0 . We used the stata taxsim9.ado interface (available at http://users.nber.org/ taxsim/taxsimcalc9/index.html) to run the Internet TaxSim program (a Fortran program).

The Internet TaxSim is a program that calculates federal and state tax variables for a hypothetical taxpayer from a given state in a given year. The program is coded based on information from federal and state tax forms and "summaries published by the Commerce Clearing House, the Advisory Commission on Intergovernmental Relations (ACIR), and the Tax 
Foundation" (Feenberg and Coutts, 1993). As described at www.nber.org/ taxsim, "[a]lthough state tax regimes differ significantly from one another, most share the basic structure of the federal tax. That is, deductions and exemptions are subtracted from adjusted gross income to obtain taxable income. A schedule converts taxable income to income before credits, from which a variety of credits, some refundable, are subtracted." These specifics of state tax codes, along with a similar tax schedule from the federal tax code, are coded into the TaxSim program.

TaxSim returns the following variables (inter alia) for each state and year: federal income tax liability, federal adjusted gross income (AGI), federal marginal tax rate, state income tax liability, state adjusted gross income, and the state marginal tax rate. Note that these federal tax variables can differ by state because of the fact that state tax payments are deductible from ordinary federal AGI for determining federal taxable income, though state taxes are not deductible for the alternative minimum tax (AMT). We calculate the average tax rate (ATR) for an individual in each state*year as the sum of state and federal tax liability divided by gross income.

As mentioned in the paper, we also constructed an alternative measure of the individual income ATR based on (1) data from a large sample of actual federal tax returns from the IRS Statistics on Income (SOI) that are housed at the NBER and (2) the NBER's non-public internal TaxSim program, which is more detailed than the public Internet TaxSim. ${ }^{1}$ These yearly SOI samples are not public but are available for use by NBER research affiliates. For this measure, we started with the same income levels for primary wage earnings and long-term capital gains as described above. For each year from 1977 to 2010 and each income level $\left(50^{\text {th }}, 95^{\text {th }}, 99^{\text {th }}\right.$, and $99.9^{\text {th }}$ percentiles of national income distribution), we then had a subsample of the full SOI sample of federal tax returns extracted for taxpayers with total wage and long-term capital gains income within $+/$ - $1 \%$ of that income level. This resulted in subsamples with roughly 150 to 750 tax returns. For each subsample, the average value was calculated for each variable that is used as an input into the TaxSim programs. These inputs include the number of dependent exemptions, rental and other income, charitable donations, mortgage interest payments, and various other credits and deductions.

Because these tax returns do not identify the state of residence of the taxpayer, one cannot generate these averages/inputs by state. However, there are two state-specific adjustments that we make in order to generate 50 state-specific versions of each yearly income-threshold vector of inputs. First, following Bakija and Gentry (2014), we apply a state-specific multiplier to the

\footnotetext{
${ }^{1}$ We thank Dan Feenberg at the NBER for extracting subsamples, for relevant income levels, from the SOI taxpayer samples and using these to calculate average values of each tax input variable used by TaxSim.
} 
national average property tax deduction. The numerator of this multiplier is calculated as the total statewide property tax revenues divided by state personal income. Property tax revenues data come from the Census Bureau's Survey of State and Loca Government Finances; personal income data come from the BEA. The denominator is the population-weighted average of this ratio across the 50 states. Thus, the multiplier measures the effective property tax rate for the average individual in the state relative to the effective property tax rate for the average individual in the nation. The multiplier for state $s$ is multiplied by the national average property tax deduction (for a given income threshold and year) to obtain an estimate of the average property tax deduction for the hypothetical taxpayer in state $s$.

The second state-specific adjustment is done internally by the TaxSim program. For a given state, the program calculates the state income tax liability based on the inputs described above (i.e., the national averages for each input variable and the state-specific property tax deduction estimate). This state income tax liability is then used as the input into the TaxSim program for the state income tax deduction. In some states, federal tax payments are deductible on the state tax return. In these cases, the program iterates between the state and federal calculations until they converge. The TaxSim program outputs estimates of AGI and state and federal tax liabilities, from which we calculate the ATR as the sum of state and federal tax liabilities divided by gross income.

This alternative approach of using averages of tax input variables based on actual samples of tax returns, rather than simply assuming zeros for various itemized deductions and for income other than wage earnings and long-term capital gains, and using the more detailed internal NBER TaxSim program, rather than the Internet TaxSim program, likely yields more accurate measures of the ATR. However, the approach requires access to the NBER's non-public SOI tax return samples and NBER's non-public internal TaxSim program, which generally is only available to NBER affiliates. Thus, for the sake of replicability, we opted to use ATR constructed as described above, involving only publicly available data and the public version of TaxSim, for the results in the paper. We note, however, that virtually all of the results in the paper are quite similar using this alternative measure of the ATR.

\section{References}

Bakija, Jon M., and William M. Gentry. "Capital Gains Taxes and Realizations: Evidence from a Long Panel of State-Level Data.” Unpublished Manuscript, Williams College.

Chirinko, Robert, and Daniel J. Wilson. "State Investment Tax Incentives: A Zero-Sum Game?" Journal of Public Economics 92(12), Dec. 2008, pp. 2362-2384. 
Moretti, E, and D. Wilson (2014) "State Incentives for Innovation, Star Scientists and Jobs: Evidence from Biotech", The Journal of Urban Economics, forthcoming

Feenberg, Daniel Richard, and Elizabeth Coutts, An Introduction to the TAXSIM Model, Journal of Policy Analysis and Management vol 12 no 1, Winter 1993, pages 189-194.

Wilson, Daniel J. (2009). "Beggar Thy Neighbor? The In-State, Out-of-State, and Aggregate Effects of R\&D Tax Credits.” Review of Economics and Statistics 91(2), 431-436. 
Table Appendix 1: Summary Statistics over 51 states-

Star Population, 99th Perc. ATR, and Corp. Income Tax

\begin{tabular}{|c|c|c|c|c|c|c|}
\hline & $\begin{array}{c}\text { Pop Star } 95 \\
(1) \\
2006 \text { value }\end{array}$ & $\begin{array}{c}\text { Pop } \begin{array}{l}\text { Star } 95 \\
(2)\end{array} \\
\text { 1977-2006\%-change }\end{array}$ & $\begin{array}{c}\text { 99th Perc. ATR } \\
\text { (3) } \\
2006 \text { value }\end{array}$ & $\begin{array}{c}\text { 99th Perc. ATR } \\
(4) \\
1977-2006 \% \text {-change }\end{array}$ & $\begin{array}{c}\text { CIT } \\
(5) \\
2006 \text { value }\end{array}$ & $\begin{array}{c}\text { CIT } \\
(6) \\
1977-2006 \% \text {-change }\end{array}$ \\
\hline Alabama & 26.0000 & -0.5667 & 0.2899 & -0.1421 & 0.0650 & 0.3000 \\
\hline Alaska & 0.0000 & -1.0000 & 0.2541 & -0.3094 & 0.0940 & 0.0000 \\
\hline Arizona & 267.0000 & 1.3421 & 0.2947 & -0.1708 & 0.0697 & -0.3362 \\
\hline Arkansas & 10.0000 & 0.0000 & 0.3171 & -0.1036 & 0.0650 & 0.0833 \\
\hline California & 3869.0000 & 1.8852 & 0.3348 & -0.1048 & 0.0884 & -0.0178 \\
\hline Colorado & 192.0000 & 0.3617 & 0.2989 & -0.1500 & 0.0463 & -0.0740 \\
\hline Connecticut & 290.0000 & -0.1667 & 0.3031 & -0.0349 & 0.0750 & -0.2500 \\
\hline Delaware & 77.0000 & -0.4539 & 0.3093 & -0.1924 & 0.0870 & 0.0000 \\
\hline $\mathrm{DC}$ & 7.0000 & -0.3000 & 0.3359 & -0.1090 & 0.0998 & 0.0081 \\
\hline Florida & 238.0000 & 0.1174 & 0.2541 & -0.1833 & 0.0550 & 0.1000 \\
\hline Georgia & 174.0000 & 1.2308 & 0.3122 & -0.1313 & 0.0600 & 0.0000 \\
\hline Hawaii & 10.0000 & 0.4286 & 0.3270 & -0.1280 & 0.0640 & -0.0054 \\
\hline Idaho & 219.0000 & 20.9000 & 0.3281 & -0.1073 & 0.0760 & 0.1692 \\
\hline Illinois & 419.0000 & -0.5117 & 0.2838 & -0.1536 & 0.0730 & 0.8250 \\
\hline Indiana & 129.0000 & -0.4921 & 0.2879 & -0.1264 & 0.0850 & 0.4167 \\
\hline Iowa & 82.0000 & 0.1549 & 0.3160 & -0.1196 & 0.1200 & 0.2000 \\
\hline Louisiana & 24.0000 & -0.6800 & 0.2946 & -0.1087 & 0.0800 & 0.0000 \\
\hline Maine & 14.0000 & 0.0769 & 0.3326 & -0.0961 & 0.0893 & 0.2757 \\
\hline Maryland & 154.0000 & -0.2261 & 0.3003 & -0.1518 & 0.0700 & 0.0000 \\
\hline Massachusetts & 645.0000 & 0.2697 & 0.3058 & -0.1613 & 0.0950 & 0.0000 \\
\hline Michigan & 470.0000 & -0.1826 & 0.2925 & -0.1711 & 0.0190 & -0.1915 \\
\hline Minnesota & 593.0000 & 2.1711 & 0.3264 & -0.1377 & 0.0980 & -0.1833 \\
\hline Mississippi & 12.0000 & -0.0769 & 0.3013 & -0.1022 & 0.0500 & 0.2500 \\
\hline Missouri & 99.0000 & -0.3694 & 0.3093 & -0.0907 & 0.0625 & 0.2500 \\
\hline Montana & 5.0000 & -0.2857 & 0.3171 & -0.1336 & 0.0675 & 0.0000 \\
\hline Nebraska & 31.0000 & -0.1389 & 0.3229 & -0.1145 & 0.0781 & 0.5778 \\
\hline Nevada & 44.0000 & 2.1429 & 0.2541 & -0.1833 & 0.0000 & -1.0000 \\
\hline New Hampshire & 66.0000 & 0.9412 & 0.2541 & -0.1833 & 0.0925 & 0.1563 \\
\hline New Jersey & 605.0000 & -0.4271 & 0.3073 & -0.0792 & 0.0900 & 0.2000 \\
\hline New Mexico & 40.0000 & 1.2222 & 0.3015 & -0.1464 & 0.0760 & 0.5200 \\
\hline New York & 1265.0000 & 0.2199 & 0.3200 & -0.1843 & 0.0750 & -0.2500 \\
\hline North Carolina & 327.0000 & 1.5349 & 0.3301 & -0.1027 & 0.0690 & 0.1500 \\
\hline North Dakota & 5.0000 & 0.2500 & 0.2943 & -0.1826 & 0.0700 & 0.1667 \\
\hline Ohio & 398.0000 & -0.4033 & 0.3141 & -0.0643 & 0.0850 & 0.0625 \\
\hline Rhode Island & 33.0000 & 0.1000 & 0.3212 & -0.1230 & 0.0900 & 0.1250 \\
\hline South Carolina & 59.0000 & 0.0727 & 0.3170 & -0.1350 & 0.0500 & -0.1667 \\
\hline South Dakota & 2.0000 & 0.0000 & 0.2541 & -0.1833 & 0.0000 & -1.0000 \\
\hline Tennessee & 91.0000 & 0.0706 & 0.2541 & -0.1833 & 0.0650 & 0.0833 \\
\hline Texas & 956.0000 & 1.0297 & 0.2541 & -0.1833 & 0.0450 & 0.0588 \\
\hline Utah & 84.0000 & 0.7500 & 0.3122 & -0.1156 & 0.0500 & 0.2500 \\
\hline Vermont & 163.0000 & 7.5789 & 0.3230 & -0.1380 & 0.0975 & 0.3000 \\
\hline Virginia & 95.0000 & -0.2857 & 0.3092 & -0.1381 & 0.0600 & 0.0000 \\
\hline Washington & 535.0000 & 4.4592 & 0.2541 & -0.1833 & 0.0000 & -1.0000 \\
\hline West Virginia & 4.0000 & -0.8750 & 0.3156 & -0.1051 & 0.0900 & 0.5000 \\
\hline Wisconsin & 216.0000 & 0.0588 & 0.3162 & -0.1666 & 0.0790 & 0.0000 \\
\hline Wyoming & 3.0000 & -0.4000 & 0.2541 & -0.1833 & 0.0000 & -1.0000 \\
\hline
\end{tabular}


Table Appendix 2: CIT Regressed on Annual Stock Return of Top Patenters

\begin{tabular}{|c|c|c|c|c|c|c|}
\hline & $\begin{array}{c}\text { No Lags } \\
\text { No State FEs }\end{array}$ & $\begin{array}{c}\text { No Lags } \\
\text { Year, State FEs }\end{array}$ & $\begin{array}{c}\text { 1-year Lag } \\
\text { No State FEs }\end{array}$ & $\begin{array}{c}\text { 1-year Lag } \\
\text { Year, State FEs }\end{array}$ & $\begin{array}{l}1-4 \text { years Lag } \\
\text { No State FEs }\end{array}$ & $\begin{array}{c}1-4 \text { years Lag } \\
\text { Year, State FEs }\end{array}$ \\
\hline Annual Stock Return Growth & $\begin{array}{l}-0.0002 \\
(0.0009)\end{array}$ & $\begin{array}{c}0.0002 \\
(0.0002)\end{array}$ & $\begin{array}{c}-0.0002 \\
(0.0009)\end{array}$ & $\begin{array}{c}0.0002 \\
(0.0002)\end{array}$ & $\begin{array}{l}-0.0002 \\
(0.0009)\end{array}$ & $\begin{array}{c}0.0001 \\
(0.0002)\end{array}$ \\
\hline Annual Stock Return Growth- 1 year lag & & & $\begin{array}{l}-0.0002 \\
(0.0009)\end{array}$ & $\begin{array}{c}0.0000 \\
(0.0002)\end{array}$ & $\begin{array}{l}-0.0002 \\
(0.0009)\end{array}$ & $\begin{array}{c}0.0000 \\
(0.0002)\end{array}$ \\
\hline Annual Stock Return Growth- 2 year lag & & & & & $\begin{array}{l}-0.0002 \\
(0.0009)\end{array}$ & $\begin{array}{c}0.0001 \\
(0.0002)\end{array}$ \\
\hline Annual Stock Return Growth- 3 year lag & & & & & $\begin{array}{c}-0.0002 \\
(0.0009)\end{array}$ & $\begin{array}{c}0.0000 \\
(0.0002)\end{array}$ \\
\hline Annual Stock Return Growth- 4 year lag & & & & & $\begin{array}{l}-0.0003 \\
(0.0009)\end{array}$ & $\begin{array}{c}0.0000 \\
(0.0002)\end{array}$ \\
\hline Joint Sig. p-value & & & .7988 & .9202 & .9934 & .9964 \\
\hline
\end{tabular}

Each column is a separate regression. Sample consists of 1527 observations over 51 states and 30 years. All regressions include year fixed effects.

Table Appendix 3: ATR Regressed on Annual Stock Return of Top Patenters

\begin{tabular}{|c|c|c|c|c|c|c|}
\hline & $\begin{array}{c}\text { No Lags } \\
\text { No State FEs }\end{array}$ & $\begin{array}{c}\text { No Lags } \\
\text { Year, State FEs }\end{array}$ & $\begin{array}{c}\text { 1-year Lag } \\
\text { No State FEs }\end{array}$ & $\begin{array}{c}\text { 1-year Lag } \\
\text { Year, State FEs }\end{array}$ & $\begin{array}{l}\text { 1-4 years Lag } \\
\text { No State FEs }\end{array}$ & $\begin{array}{c}1-4 \text { years Lag } \\
\text { Year, State FEs }\end{array}$ \\
\hline Annual Stock Return Growth & $\begin{array}{c}0.0008 \\
(0.0007)\end{array}$ & $\begin{array}{c}0.0000 \\
(0.0002)\end{array}$ & $\begin{array}{c}0.0009 \\
(0.0007)\end{array}$ & $\begin{array}{c}0.0000 \\
(0.0002)\end{array}$ & $\begin{array}{c}0.0008 \\
(0.0007)\end{array}$ & $\begin{array}{c}0.0000 \\
(0.0002)\end{array}$ \\
\hline Annual Stock Return Growth- 1 year lag & & & $\begin{array}{c}0.0007 \\
(0.0007)\end{array}$ & $\begin{array}{l}-0.0000 \\
(0.0002)\end{array}$ & $\begin{array}{c}0.0007 \\
(0.0007)\end{array}$ & $\begin{array}{l}-0.0000 \\
(0.0002)\end{array}$ \\
\hline Annual Stock Return Growth- 2 year lag & & & & & $\begin{array}{c}0.0008 \\
(0.0007)\end{array}$ & $\begin{array}{c}0.0000 \\
(0.0002)\end{array}$ \\
\hline Annual Stock Return Growth- 3 year lag & & & & & $\begin{array}{c}0.0009 \\
(0.0007)\end{array}$ & $\begin{array}{c}0.0001 \\
(0.0002)\end{array}$ \\
\hline Annual Stock Return Growth- 4 year lag & & & & & $\begin{array}{c}0.0009 \\
(0.0007)\end{array}$ & $\begin{array}{c}0.0002 \\
(0.0002)\end{array}$ \\
\hline Joint Sig. p-value & & & .3078 & .9845 & .2787 & .7465 \\
\hline
\end{tabular}

${ }^{*} p<0.10,{ }^{* *} p<0.05,{ }^{* * *} p<0.01$

Each column is a separate regression. Sample consists of 1527 observations over 51 states and 30 years. All regressions include year fixed effects. 
Table Appendix 4: ITC Regressed on Annual Stock Return of Top Patenters

\begin{tabular}{|c|c|c|c|c|c|c|}
\hline & $\begin{array}{c}\text { No Lags } \\
\text { No State FEs }\end{array}$ & $\begin{array}{c}\text { No Lags } \\
\text { Year, State FEs }\end{array}$ & $\begin{array}{c}\text { 1-year Lag } \\
\text { No State FEs }\end{array}$ & $\begin{array}{c}\text { 1-year Lag } \\
\text { Year, State FEs }\end{array}$ & $\begin{array}{l}\text { 1-4 years Lag } \\
\text { No State FEs }\end{array}$ & $\begin{array}{c}\text { 1-4 years Lag } \\
\text { Year, State FEs }\end{array}$ \\
\hline Annual Stock Return Growth & $\begin{array}{c}0.0002 \\
(0.0007)\end{array}$ & $\begin{array}{c}0.0005 \\
(0.0005)\end{array}$ & $\begin{array}{c}0.0002 \\
(0.0007)\end{array}$ & $\begin{array}{c}0.0006 \\
(0.0005)\end{array}$ & $\begin{array}{c}0.0002 \\
(0.0007)\end{array}$ & $\begin{array}{c}0.0008 \\
(0.0005)\end{array}$ \\
\hline Annual Stock Return Growth- 1 year lag & & & $\begin{array}{c}0.0000 \\
(0.0007)\end{array}$ & $\begin{array}{c}0.0005 \\
(0.0005)\end{array}$ & $\begin{array}{c}-0.0000 \\
(0.0008)\end{array}$ & $\begin{array}{c}0.0007 \\
(0.0005)\end{array}$ \\
\hline Annual Stock Return Growth- 2 year lag & & & & & $\begin{array}{c}0.0000 \\
(0.0008)\end{array}$ & $\begin{array}{c}0.0006 \\
(0.0005)\end{array}$ \\
\hline Annual Stock Return Growth- 3 year lag & & & & & $\begin{array}{c}-0.0001 \\
(0.0008)\end{array}$ & $\begin{array}{c}0.0006 \\
(0.0005)\end{array}$ \\
\hline Annual Stock Return Growth- 4 year lag & & & & & $\begin{array}{l}-0.0004 \\
(0.0008)\end{array}$ & $\begin{array}{c}0.0002 \\
(0.0005)\end{array}$ \\
\hline Joint Sig. p-value & & & .9811 & .3425 & .9898 & .3562 \\
\hline
\end{tabular}

Each column is a separate regression. Sample consists of 1527 observations over 51 states and 30 years. All regressions include year fixed effects.

Table Appendix 5: RD Regressed on Annual Stock Return of Top Patenters

\begin{tabular}{|c|c|c|c|c|c|c|}
\hline & $\begin{array}{c}\text { No Lags } \\
\text { No State FEs }\end{array}$ & $\begin{array}{c}\text { No Lags } \\
\text { Year, State FEs }\end{array}$ & $\begin{array}{c}\text { 1-year Lag } \\
\text { No State FEs }\end{array}$ & $\begin{array}{c}\text { 1-year Lag } \\
\text { Year, State FEs }\end{array}$ & $\begin{array}{l}1-4 \text { years Lag } \\
\text { No State FEs }\end{array}$ & $\begin{array}{c}\text { 1-4 years Lag } \\
\text { Year, State FEs }\end{array}$ \\
\hline Annual Stock Return Growth & $\begin{array}{c}0.0008 \\
(0.0014)\end{array}$ & $\begin{array}{c}0.0011 \\
(0.0011)\end{array}$ & $\begin{array}{c}0.0008 \\
(0.0014)\end{array}$ & $\begin{array}{c}0.0012 \\
(0.0011)\end{array}$ & $\begin{array}{c}0.0008 \\
(0.0015)\end{array}$ & $\begin{array}{c}0.0012 \\
(0.0011)\end{array}$ \\
\hline Annual Stock Return Growth- 1 year lag & & & $\begin{array}{c}0.0004 \\
(0.0014)\end{array}$ & $\begin{array}{c}0.0007 \\
(0.0011)\end{array}$ & $\begin{array}{c}0.0004 \\
(0.0015)\end{array}$ & $\begin{array}{c}0.0007 \\
(0.0011)\end{array}$ \\
\hline Annual Stock Return Growth- 2 year lag & & & & & $\begin{array}{c}0.0001 \\
(0.0015)\end{array}$ & $\begin{array}{c}0.0005 \\
(0.0011)\end{array}$ \\
\hline Annual Stock Return Growth- 3 year lag & & & & & $\begin{array}{c}0.0000 \\
(0.0015)\end{array}$ & $\begin{array}{c}0.0004 \\
(0.0011)\end{array}$ \\
\hline Annual Stock Return Growth- 4 year lag & & & & & $\begin{array}{c}0.0000 \\
(0.0015) \\
\end{array}$ & $\begin{array}{c}0.0003 \\
(0.0011) \\
\end{array}$ \\
\hline Joint Sig. p-value & & & .7771 & .5395 & .9993 & .9469 \\
\hline
\end{tabular}

${ }^{*} p<0.10,{ }^{* *} p<0.05,{ }^{* * *} p<0.01$

Each column is a separate regression. Sample consists of 1527 observations over 51 states and 30 years. All regressions include year fixed effects. 
Table Appendix 6: The Effect of Net-of-Tax Rates on Outmigration of Star Scientists: Baseline Models

\begin{tabular}{|c|c|c|c|c|c|c|c|c|}
\hline MTR, 99th Perc. (1 - mtr) & $\begin{array}{c}(1) \\
1.5886^{*} \\
(0.8318)\end{array}$ & $\begin{array}{c}(2) \\
2.4464^{* * *} \\
(0.5660)\end{array}$ & $\begin{array}{c}(3) \\
2.3671^{* * *} \\
(0.5851)\end{array}$ & $\begin{array}{c}(4) \\
1.7007^{* * *} \\
(0.5240)\end{array}$ & $\begin{array}{c}(5) \\
2.3202^{* * *} \\
(0.5774)\end{array}$ & $\begin{array}{c}(6) \\
2.3621^{* * *} \\
(0.5533)\end{array}$ & $\begin{array}{c}(7) \\
1.6966^{* * *} \\
(0.6045)\end{array}$ & $\begin{array}{c}(8) \\
3.0825^{* * *} \\
(0.9437)\end{array}$ \\
\hline State CIT Rate (1 - cit) & $\begin{array}{c}-3.5571^{* * *} \\
(0.9292)\end{array}$ & $\begin{array}{l}1.7468^{* *} \\
(0.6957)\end{array}$ & $\begin{array}{l}1.6077^{* *} \\
(0.6914)\end{array}$ & $\begin{array}{l}1.3334^{* *} \\
(0.6011)\end{array}$ & $\begin{array}{c}0.9661 \\
(0.7297)\end{array}$ & $\begin{array}{l}1.6550^{* *} \\
(0.6456)\end{array}$ & $\begin{array}{c}1.8861^{* * *} \\
(0.6410)\end{array}$ & $\begin{array}{c}1.6137 \\
(1.1929)\end{array}$ \\
\hline State ITC $(1+$ itc $)$ & $\begin{array}{c}5.1639^{* * *} \\
(1.4461)\end{array}$ & $\begin{array}{c}1.7425^{* * *} \\
(0.4532)\end{array}$ & $\begin{array}{c}1.6678^{* * *} \\
(0.5352)\end{array}$ & $\begin{array}{c}1.6131^{* * *} \\
(0.5646)\end{array}$ & $\begin{array}{c}1.7213^{* * *} \\
(0.4949)\end{array}$ & $\begin{array}{c}1.6738^{* * *} \\
(0.5685)\end{array}$ & $\begin{array}{c}2.2907^{* * *} \\
(0.7532)\end{array}$ & $\begin{array}{l}1.4562^{*} \\
(0.7579)\end{array}$ \\
\hline R\&D Credit $(1+$ cred $)$ & $\begin{array}{c}3.2494^{* * *} \\
(0.6970)\end{array}$ & $\begin{array}{l}0.3407^{*} \\
(0.1974)\end{array}$ & $\begin{array}{l}0.3580^{*} \\
(0.2145)\end{array}$ & $\begin{array}{l}-0.0291 \\
(0.2135)\end{array}$ & $\begin{array}{c}0.0780 \\
(0.2099)\end{array}$ & $\begin{array}{l}0.3937^{*} \\
(0.2251)\end{array}$ & $\begin{array}{c}1.0259^{* * *} \\
(0.2789)\end{array}$ & $\begin{array}{l}-0.4188 \\
(0.3355)\end{array}$ \\
\hline Origin, Destination State FE & No & Yes & No & No & No & No & No & No \\
\hline Origin*Destination Pair FE & No & No & Yes & Yes & Yes & Yes & Yes & Yes \\
\hline Origin Region*Year FE & No & No & No & Yes & No & No & No & No \\
\hline Destination Region*Year FE & No & No & No & No & Yes & No & No & No \\
\hline $\begin{array}{l}\text { Origin \& Destination Pair } \\
\text { Region*Year FE }\end{array}$ & No & No & No & No & No & Yes & No & No \\
\hline Origin State*Year FE & No & No & No & No & No & No & Yes & No \\
\hline Destination State*Year FE & No & No & No & No & No & No & No & Yes \\
\hline
\end{tabular}

Notes: Each entry is from a separate regression. Coefficients are estimates of $\eta$ or $\eta^{\prime}$ from equation (3). Standard errors in parentheses, with three-way clustering by origin-state*year, destination-state*year, and state-pair. All regressions include year fixed effects, and have 15247 observations. ${ }^{*} p<0.10,{ }^{* *} p<0.05,{ }^{* * *} p<0.01$ 
Table Appendix 7: Asymmetric Effects for Origin and Destination Taxes

\begin{tabular}{|c|c|c|}
\hline MTR, 99th Perc., Origin (1 - mtr) & $\begin{array}{c}(1) \\
-3.2053^{* * *} \\
(0.9538)\end{array}$ & $\begin{array}{c}(2) \\
-2.5043^{* * *} \\
(0.8470)\end{array}$ \\
\hline MTR, 99th Perc., Dest. (1 - mtr) & $\begin{array}{l}1.4591^{* *} \\
(0.6724)\end{array}$ & $\begin{array}{c}2.2080^{* * *} \\
(0.7055)\end{array}$ \\
\hline State CIT Rate, Origin (1 - cit) & $\begin{array}{c}-1.7581 \\
(1.1944)\end{array}$ & $\begin{array}{l}-2.0172^{*} \\
(1.1061)\end{array}$ \\
\hline State CIT Rate, Dest. (1 - cit) & $\begin{array}{l}1.4096^{*} \\
(0.7712)\end{array}$ & $\begin{array}{c}1.2425 \\
(0.7669)\end{array}$ \\
\hline State ITC, Origin $(1+$ itc $)$ & $\begin{array}{c}-1.4770^{* *} \\
(0.7464)\end{array}$ & $\begin{array}{r}-1.2906^{*} \\
(0.7170)\end{array}$ \\
\hline State ITC, Dest. $(1+$ itc $)$ & $\begin{array}{l}1.8780^{* *} \\
(0.7325)\end{array}$ & $\begin{array}{c}2.0809^{* *} \\
(0.8361)\end{array}$ \\
\hline R\&D Credit, Origin $(1+$ cred $)$ & $\begin{array}{c}0.2497 \\
(0.3330)\end{array}$ & $\begin{array}{c}0.4044 \\
(0.3298)\end{array}$ \\
\hline R\&D Credit, Dest. $(1+$ cred $)$ & $\begin{array}{c}0.9562^{* * *} \\
(0.2955)\end{array}$ & $\begin{array}{c}1.1790^{* * *} \\
(0.3317)\end{array}$ \\
\hline Origin*Destination Pair FE & Yes & Yes \\
\hline $\begin{array}{l}\text { Origin \& Destination Pair } \\
\text { Region*Year FE }\end{array}$ & No & Yes \\
\hline
\end{tabular}

Notes: Each column is from a separate regression. Standard errors

in parentheses, with three-way clustering by origin-state*year,

destination-state*year, and state-pair. All regressions include year fixed

effects, and have 15247 observations. ${ }^{*} p<0.10,{ }^{* *} p<0.05,{ }^{* * *} p<0.01$ 
Table Appendix 8: Number of State Pairs with no flow, 1977-2006

\begin{tabular}{lcc}
\hline \hline & State Pairs & Average \\
\hline 1977 & 2178.00 & 210.49 \\
1978 & 2150.00 & 208.92 \\
1979 & 2171.00 & 203.82 \\
1980 & 2235.00 & 155.39 \\
1981 & 2219.00 & 151.98 \\
1982 & 2235.00 & 147.18 \\
1983 & 2170.00 & 155.68 \\
1984 & 2194.00 & 165.06 \\
1985 & 2153.00 & 182.20 \\
1986 & 2150.00 & 188.59 \\
1987 & 2110.00 & 219.88 \\
1988 & 2140.00 & 199.25 \\
1989 & 2097.00 & 220.45 \\
1990 & 2045.00 & 244.92 \\
1991 & 2066.00 & 262.49 \\
1992 & 2016.00 & 295.65 \\
1993 & 1994.00 & 330.78 \\
1994 & 1934.00 & 392.65 \\
1995 & 1941.00 & 324.35 \\
1996 & 1972.00 & 355.69 \\
1997 & 1918.00 & 410.31 \\
1998 & 1928.00 & 376.80 \\
1999 & 1900.00 & 428.69 \\
2000 & 1877.00 & 407.41 \\
2001 & 1894.00 & 431.61 \\
2002 & 1889.00 & 444.51 \\
2003 & 1932.00 & 394.06 \\
2004 & 1948.00 & 376.88 \\
2005 & 1948.00 & 353.82 \\
2006 & 2037.00 & 280.54 \\
\hline \hline Notes: First column shows the number \\
of origin-destination-year cells \\
that have zero scientist flows. \\
Second column shows the average \\
(across states) number of star \\
scientists in that year. \\
\hline
\end{tabular}


Table Appendix 9: Number of Years with no Migration Flow, by state-pair

\section{Destination State}

\section{Origin}

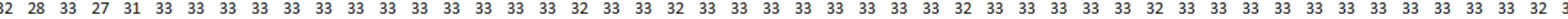

AR

$A Z$

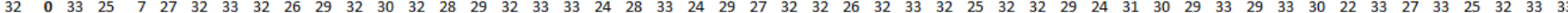

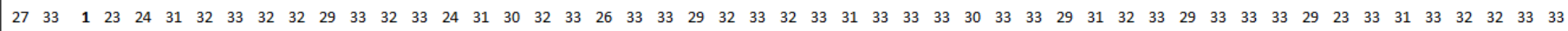

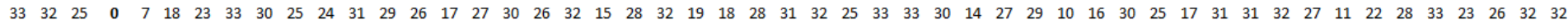

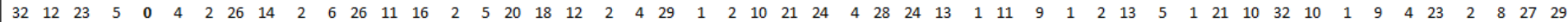

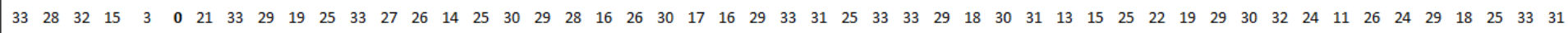

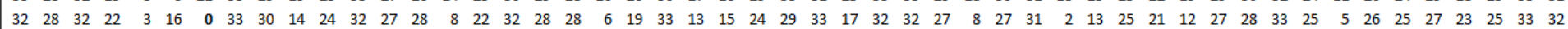

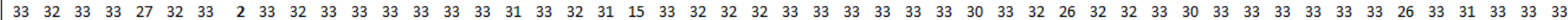

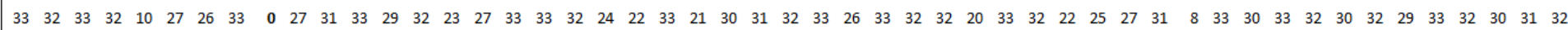

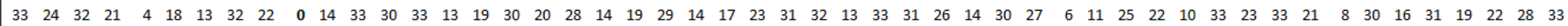

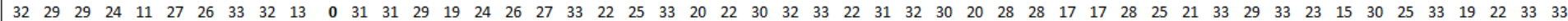

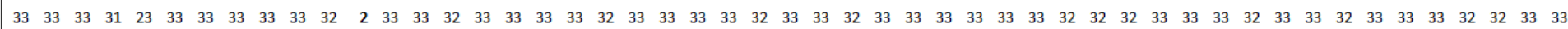

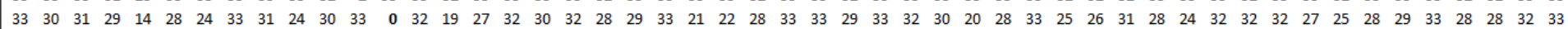

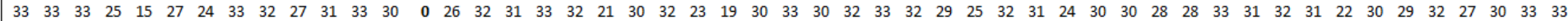

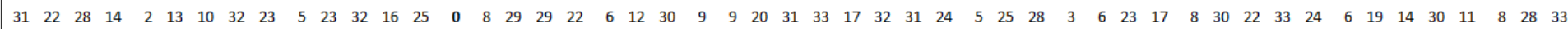

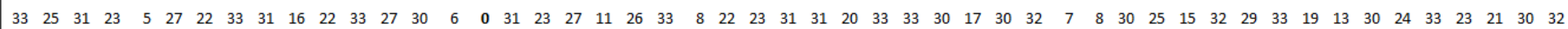

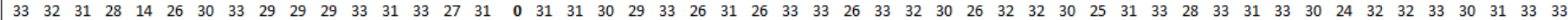

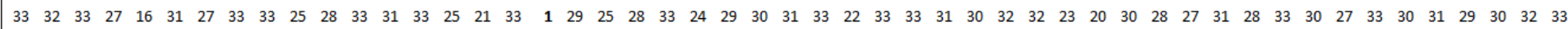

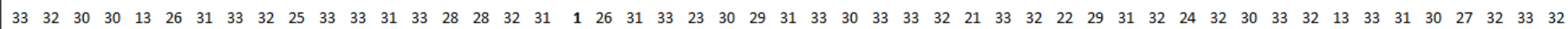

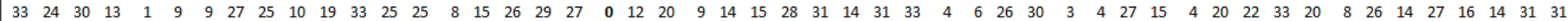

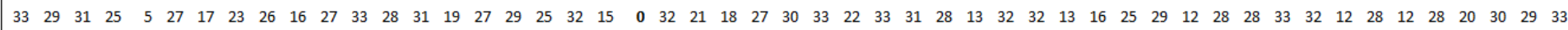

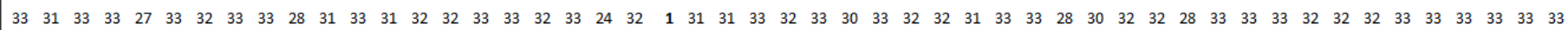

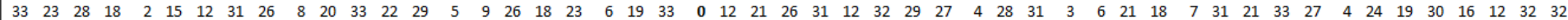

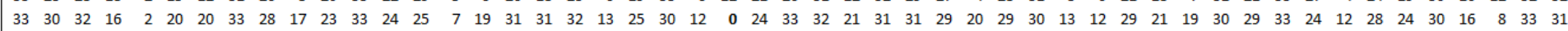

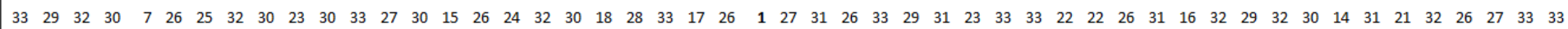

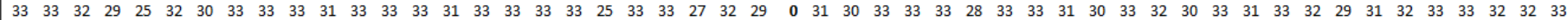

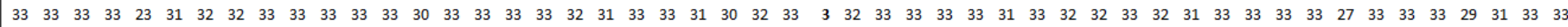

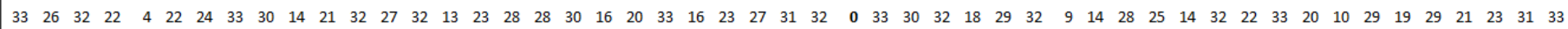

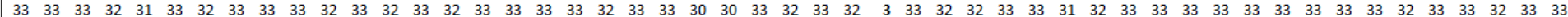

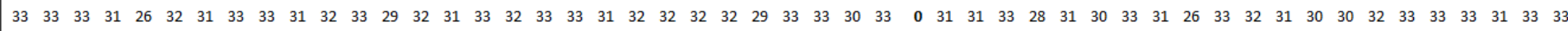

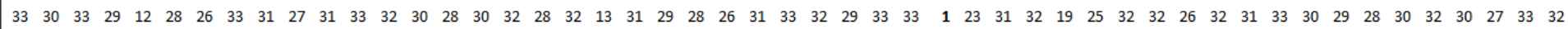

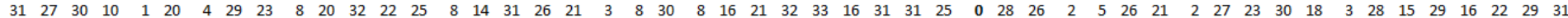

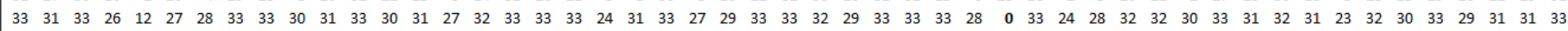

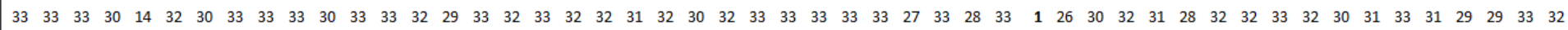

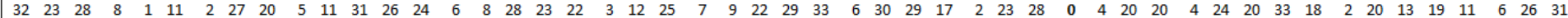

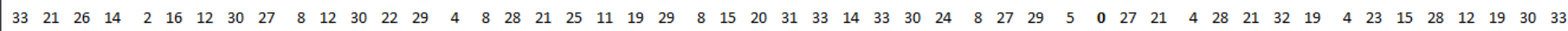

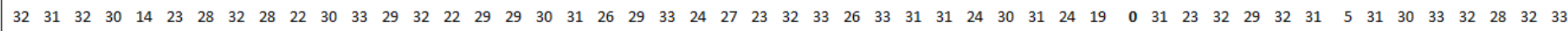

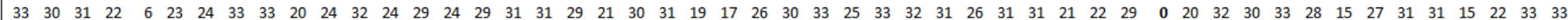

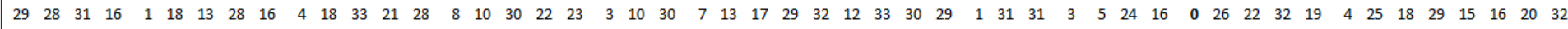

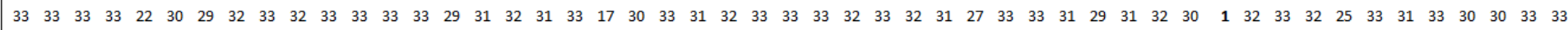

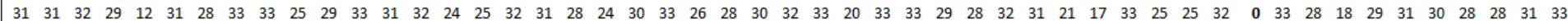

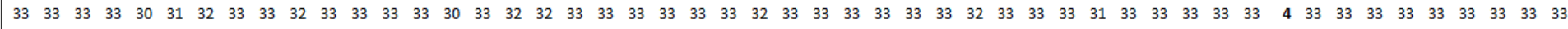

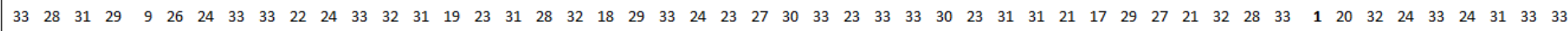

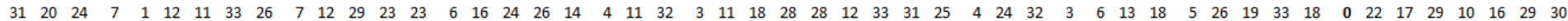

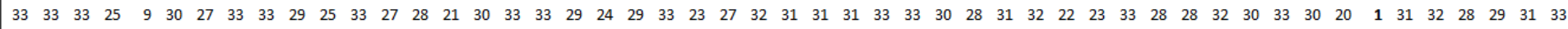

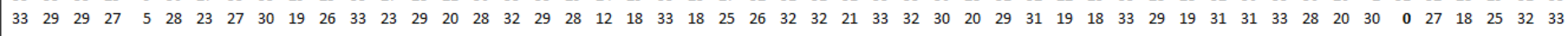

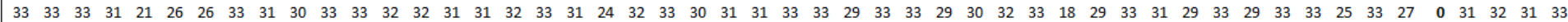

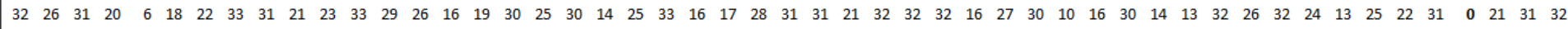

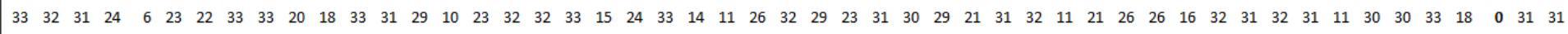

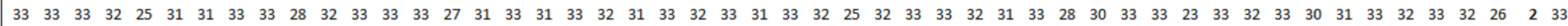

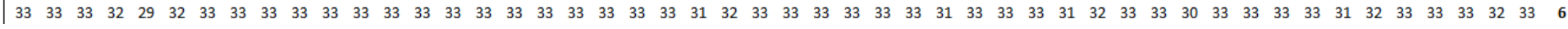

Table Appendix 10: Linear Probability Estimates

\begin{tabular}{lc}
\hline \hline & $(1)$ \\
\hline ATR, 99th Perc. (1 - atr) & 0.0054 \\
& $(0.0559)$ \\
State CIT Rate $(1-$ cit $)$ & -0.1053 \\
& $(0.0774)$ \\
State ITC $(1+$ itc $)$ & -0.0039 \\
& $(0.0295)$ \\
R\&D Credit $(1+$ cred $)$ & -0.0067 \\
& $(0.0164)$ \\
\hline Joint Significance (p-value) & .7120000000000001 \\
\hline Origin*Destination Pair FE & Yes
\end{tabular}

Notes: Each column is from a separate regression.

Standard errors from Driscoll-Kraay estimator based

on maximum 6 years lag in parentheses. Regression includes year fixed effects, and have 84150 observations.

${ }^{*} p<0.10,{ }^{* *} p<0.05,{ }^{* * *} p<0.01$ 
Table Appendix 11:

The Effect of Net-of-Tax Rates on Outmigration of Star Scientists: Estimates based on Alternative Definitions of Stars

Table Panel A: The Effect of Net-of-Tax Rates on Outmigration of Star Scientists: Baseline Models

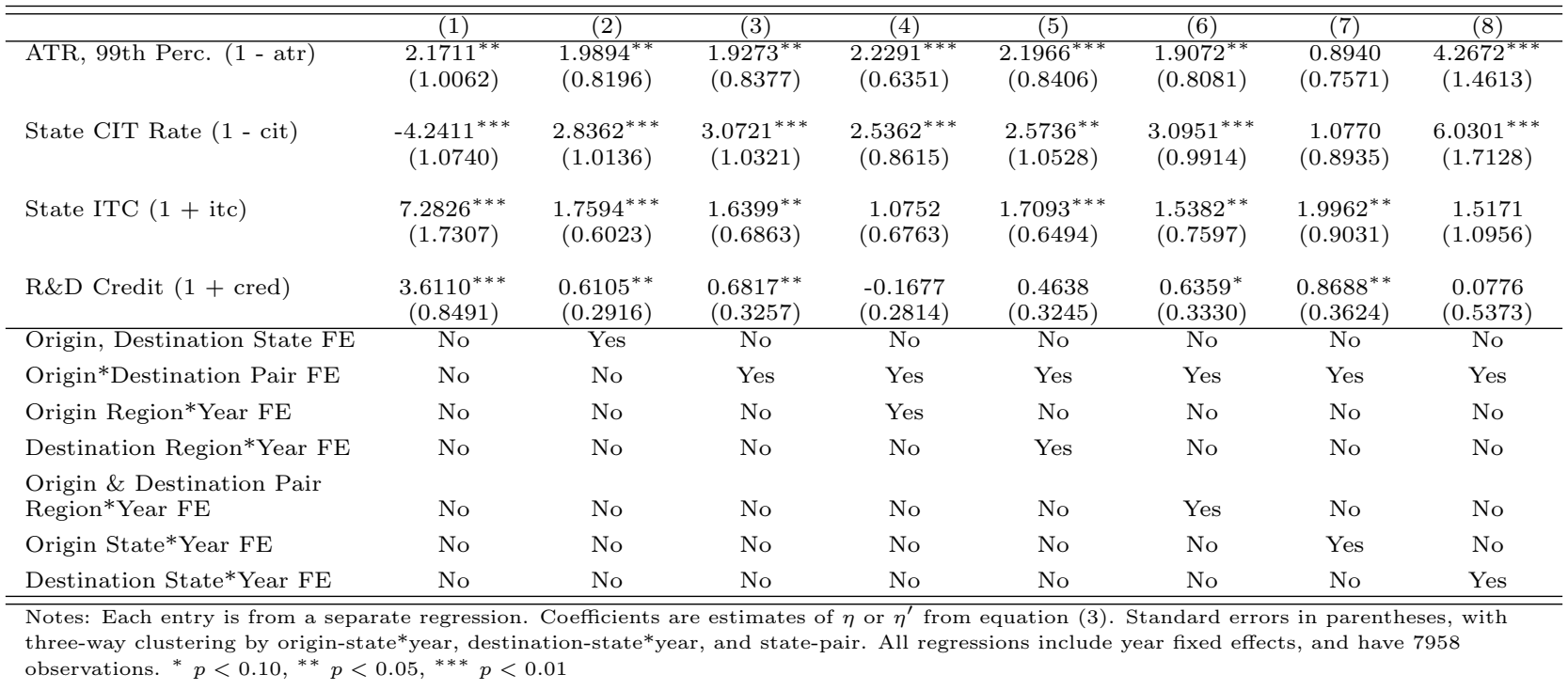

Table Panel B: The Effect of Net-of-Tax Rates on Outmigration of Star Scientists: Baseline Models

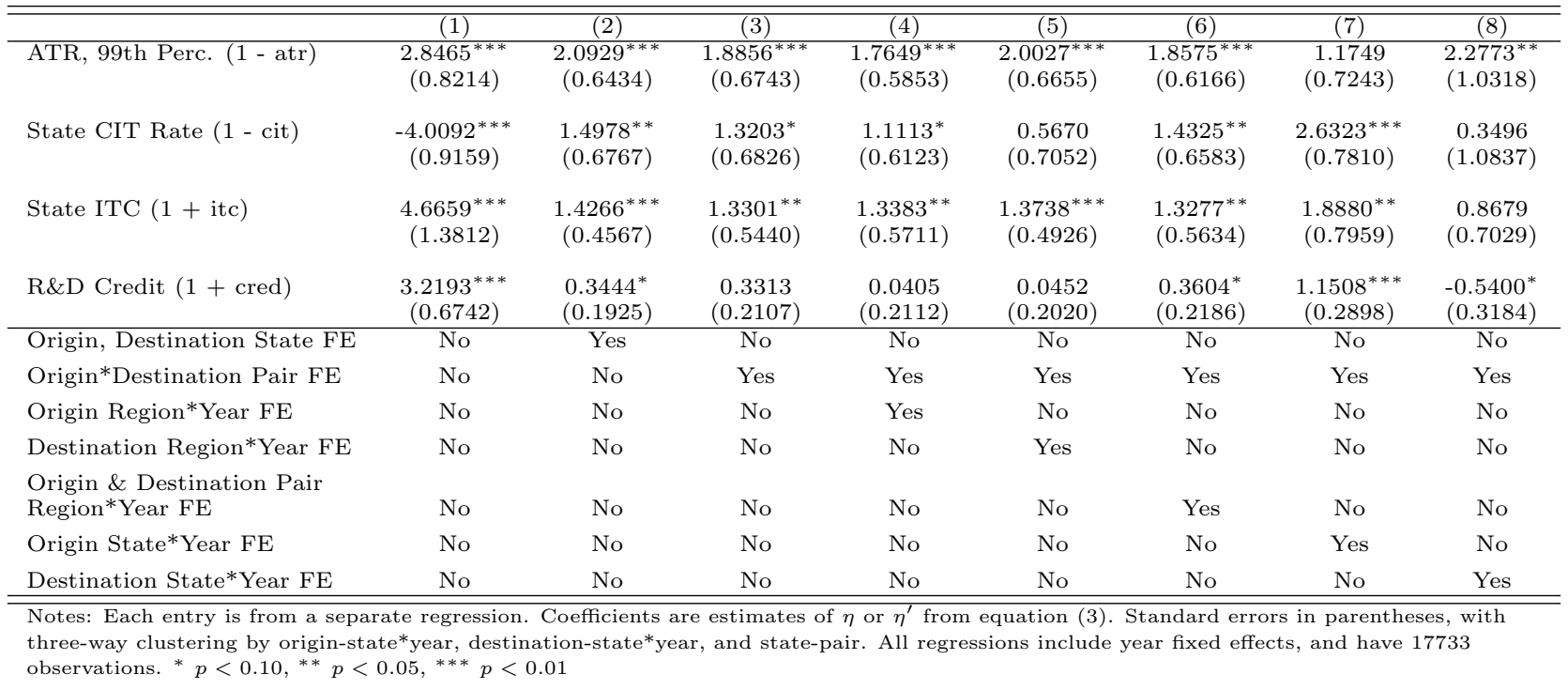


Table Appendix 12: The Effect of Net-of-tax Rates on Outmigration of Star Scientists: Estimates based on Definition of Stars that depend on Patent Citations

\begin{tabular}{|c|c|c|c|c|c|c|c|c|}
\hline ATR, 99th Perc. (1 - atr) & $\begin{array}{c}(1) \\
2.6186^{* * *} \\
(0.8520)\end{array}$ & $\begin{array}{c}(2) \\
2.2226^{* * *} \\
(0.6415)\end{array}$ & $\begin{array}{c}(3) \\
2.0234^{* * *} \\
(0.6678)\end{array}$ & $\begin{array}{c}(4) \\
1.9504^{* * *} \\
(0.5584)\end{array}$ & $\begin{array}{c}(5) \\
2.1599^{* * *} \\
(0.6693)\end{array}$ & $\begin{array}{c}(6) \\
2.0327^{* * *} \\
(0.6276)\end{array}$ & $\begin{array}{c}(7) \\
0.9862 \\
(0.6339)\end{array}$ & $\begin{array}{c}(8) \\
3.1391^{* * *} \\
(1.0993)\end{array}$ \\
\hline State CIT Rate (1 - cit) & $\begin{array}{c}-3.7902^{* * *} \\
(0.9604)\end{array}$ & $\begin{array}{c}2.0080^{* * *} \\
(0.7683)\end{array}$ & $\begin{array}{l}1.8599^{* *} \\
(0.7771)\end{array}$ & $\begin{array}{l}1.2626^{*} \\
(0.6605)\end{array}$ & $\begin{array}{c}1.2745 \\
(0.8029)\end{array}$ & $\begin{array}{c}1.9042^{* * *} \\
(0.7347)\end{array}$ & $\begin{array}{l}1.5694^{* *} \\
(0.6929)\end{array}$ & $\begin{array}{c}2.8082^{* *} \\
(1.2983)\end{array}$ \\
\hline State ITC $(1+$ itc $)$ & $\begin{array}{c}6.0377^{* * *} \\
(1.5297)\end{array}$ & $\begin{array}{c}1.9363^{* * *} \\
(0.4946)\end{array}$ & $\begin{array}{c}1.7948^{* * *} \\
(0.5725)\end{array}$ & $\begin{array}{c}1.6790^{* * *} \\
(0.5839)\end{array}$ & $\begin{array}{c}1.8019^{* * *} \\
(0.5280)\end{array}$ & $\begin{array}{c}1.7928^{* * *} \\
(0.6110)\end{array}$ & $\begin{array}{c}2.5816^{* * *} \\
(0.7971)\end{array}$ & $\begin{array}{l}1.5959^{*} \\
(0.8193)\end{array}$ \\
\hline R\&D Credit $(1+$ cred $)$ & $\begin{array}{c}3.5257^{* * *} \\
(0.7304)\end{array}$ & $\begin{array}{l}0.3718^{*} \\
(0.2133)\end{array}$ & $\begin{array}{l}0.3856^{*} \\
(0.2305)\end{array}$ & $\begin{array}{l}-0.1036 \\
(0.2221)\end{array}$ & $\begin{array}{c}0.0997 \\
(0.2239)\end{array}$ & $\begin{array}{l}0.4202^{*} \\
(0.2396)\end{array}$ & $\begin{array}{c}0.9224^{* * *} \\
(0.2926)\end{array}$ & $\begin{array}{l}-0.3593 \\
(0.3509)\end{array}$ \\
\hline Origin, Destination State FE & No & Yes & No & No & No & No & No & No \\
\hline Origin*Destination Pair FE & No & No & Yes & Yes & Yes & Yes & Yes & Yes \\
\hline Origin Region*Year FE & No & No & No & Yes & No & No & No & No \\
\hline Destination Region*Year FE & No & No & No & No & Yes & No & No & No \\
\hline $\begin{array}{l}\text { Origin \& Destination Pair } \\
\text { Region*Year FE }\end{array}$ & No & No & No & No & No & Yes & No & No \\
\hline Destination State*Year FE & No & No & No & No & No & No & No & Yes \\
\hline
\end{tabular}


Table Appendix 13: The Effect of Net-of-Tax Rates on Outmigration of Star Scientists: Estimates based on Alternative Levels of Personal Income

Table Panel A: Tax Variables Included Simultaneously, Star 95th Percentile

\begin{tabular}{|c|c|c|c|c|c|c|c|c|}
\hline ATR, 95th Perc. $(1$ - atr $)$ & $\begin{array}{c}(1) \\
5.0161^{\text {*** }} \\
(0.8339)\end{array}$ & $\begin{array}{c}(2) \\
4.6004^{* * *} \\
(0.7307)\end{array}$ & $\begin{array}{c}(3) \\
4.5323^{* * *} \\
(0.7617)\end{array}$ & $\begin{array}{c}(4) \\
4.2035^{* * *} \\
(0.6509)\end{array}$ & $\begin{array}{c}(5) \\
4.7227^{* * *} \\
(0.7591)\end{array}$ & $\begin{array}{c}(6) \\
4.5654^{* * *} \\
(0.6990)\end{array}$ & $\begin{array}{c}(7) \\
1.9361^{* * *} \\
(0.6672)\end{array}$ & $\begin{array}{c}(8) \\
7.0223^{* * *} \\
(1.1684)\end{array}$ \\
\hline State CIT Rate (1 - cit) & $\begin{array}{c}-4.6332^{* * *} \\
(0.9332)\end{array}$ & $\begin{array}{l}1.4632^{* *} \\
(0.6705)\end{array}$ & $\begin{array}{l}1.3548^{* *} \\
(0.6678)\end{array}$ & $\begin{array}{l}0.9650^{*} \\
(0.5768)\end{array}$ & $\begin{array}{c}0.6218 \\
(0.6939)\end{array}$ & $\begin{array}{l}1.3997^{* *} \\
(0.6200)\end{array}$ & $\begin{array}{c}1.8682^{* * *} \\
(0.6425)\end{array}$ & $\begin{array}{l}1.1545 \\
(1.0598)\end{array}$ \\
\hline State ITC $(1+$ itc $)$ & $\begin{array}{c}6.4883^{* * *} \\
(1.4511)\end{array}$ & $\begin{array}{c}2.2648^{* * *} \\
(0.4777)\end{array}$ & $\begin{array}{c}2.1822^{* * *} \\
(0.5582)\end{array}$ & $\begin{array}{c}2.1447^{* * *} \\
(0.5685)\end{array}$ & $\begin{array}{c}2.2990^{* * *} \\
(0.5173)\end{array}$ & $\begin{array}{c}2.1927^{* * *} \\
(0.5906)\end{array}$ & $\begin{array}{c}2.4894^{* * *} \\
(0.7702)\end{array}$ & $\begin{array}{c}2.2902^{* * *} \\
(0.7875)\end{array}$ \\
\hline R\&D Credit $(1+$ cred $)$ & $\begin{array}{c}3.2264^{* * *} \\
(0.7130)\end{array}$ & $\begin{array}{c}0.3004 \\
(0.2007)\end{array}$ & $\begin{array}{c}0.3309 \\
(0.2184)\end{array}$ & $\begin{array}{l}-0.0723 \\
(0.2186)\end{array}$ & $\begin{array}{c}0.0315 \\
(0.2090)\end{array}$ & $\begin{array}{c}0.3668 \\
(0.2287)\end{array}$ & $\begin{array}{c}1.0148^{* * *} \\
(0.2908)\end{array}$ & $\begin{array}{l}-0.4608 \\
(0.3201)\end{array}$ \\
\hline Origin, Destination State FE & No & Yes & No & No & No & No & No & No \\
\hline Origin*Destination Pair FE & No & No & Yes & Yes & Yes & Yes & Yes & Yes \\
\hline Origin Region*Year FE & No & No & No & Yes & No & No & No & No \\
\hline Destination Region*Year FE & No & No & No & No & Yes & No & No & No \\
\hline $\begin{array}{l}\text { Origin \& Destination Pair } \\
\text { Region*Year FE }\end{array}$ & No & No & No & No & No & Yes & No & No \\
\hline Origin State*Year FE & No & No & No & No & No & No & Yes & No \\
\hline Destination State*Year FE & No & No & No & No & No & No & No & Yes \\
\hline
\end{tabular}

Standard errors in parentheses

Each entry is from a separate regression. Coefficients are estimates of $\eta$ or $\eta^{\prime}$ from equation (3).

Standard errors in parentheses, with three-way clustering by origin-state*year, destination-state*year, and state-pair.

All regressions include year fixed effects, and have 15247 observations.

${ }^{*} p<0.10,{ }^{* *} p<0.05,{ }^{* * *} p<0.01$

Table Panel B: Tax Variables Included Simultaneously, Star 95th Percentile

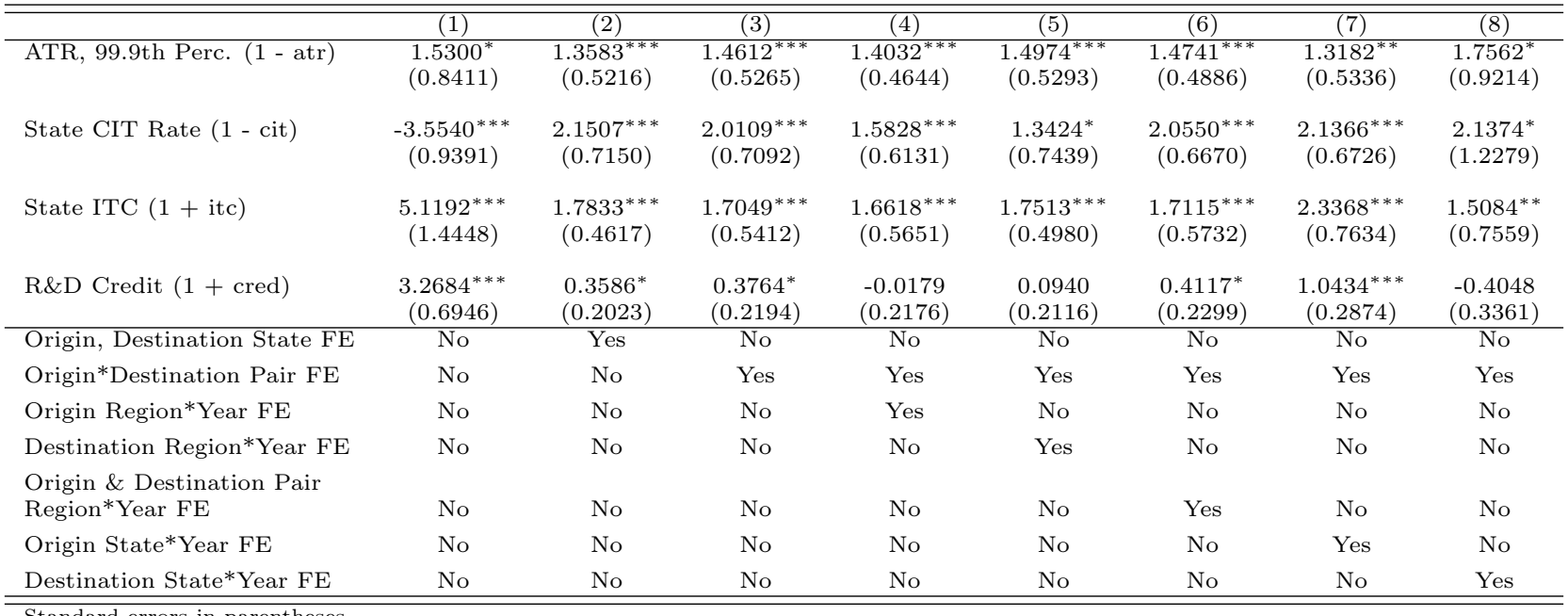

Standard errors in parentheses

Each entry is from a separate regression. Coefficients are estimates of $\eta$ or $\eta^{\prime}$ from equation (3).

Standard errors in parentheses, with three-way clustering by origin-state*year, destination-state*year, and state-pair.

All regressions include year fixed effects, and have 15247 observations.

${ }^{*} p<0.10,{ }^{* *} p<0.05,{ }^{* * *} p<0.01$ 


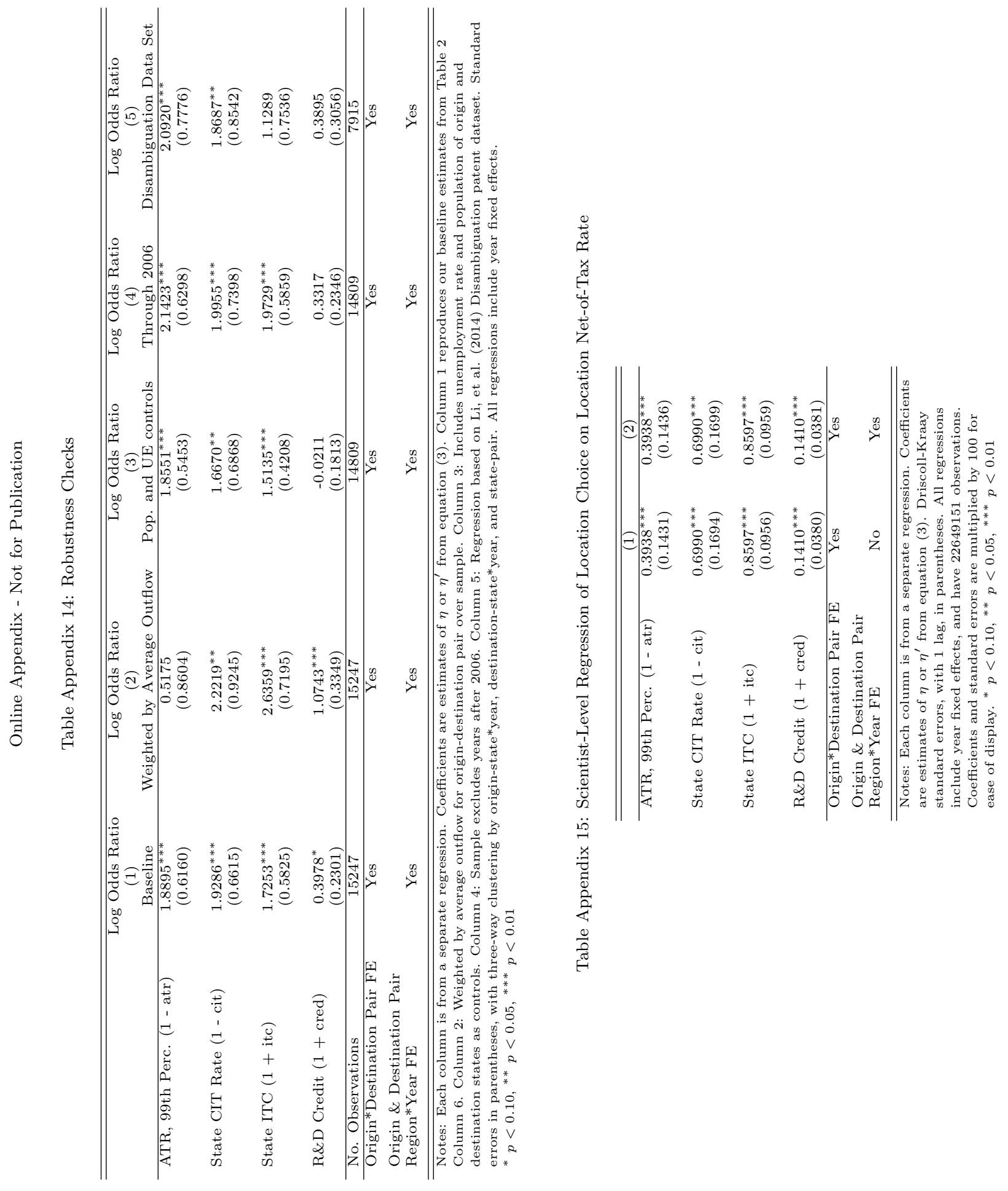




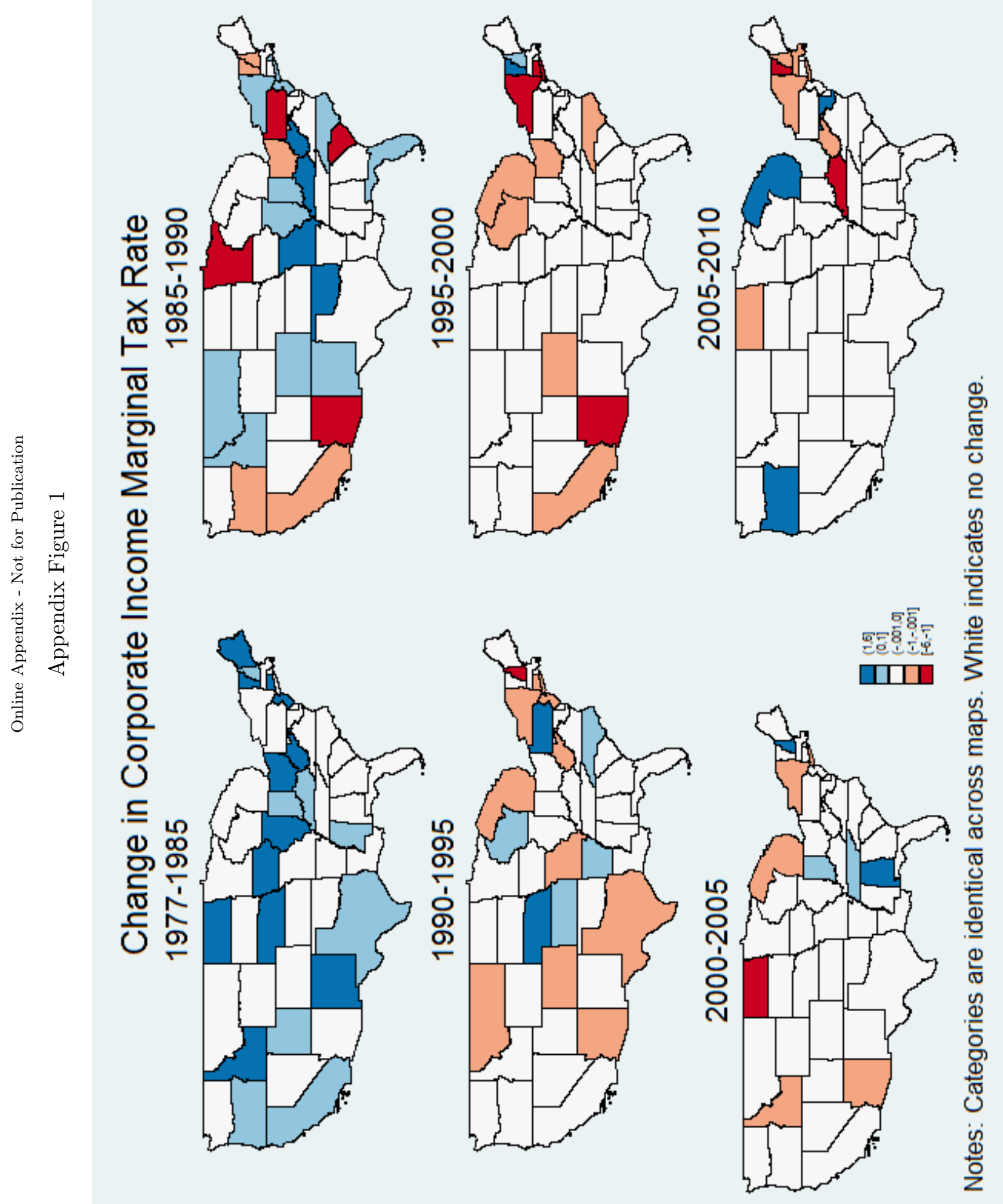




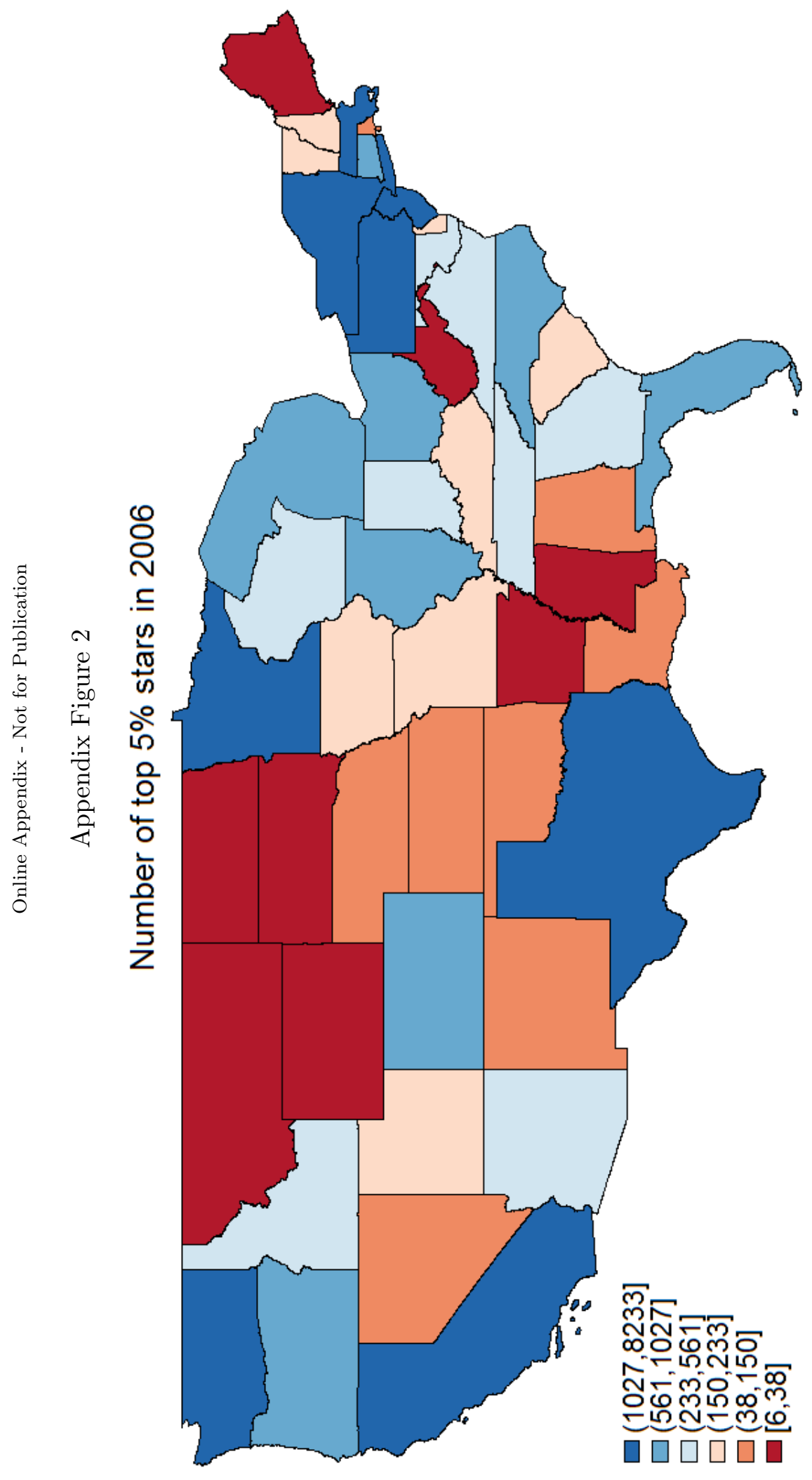




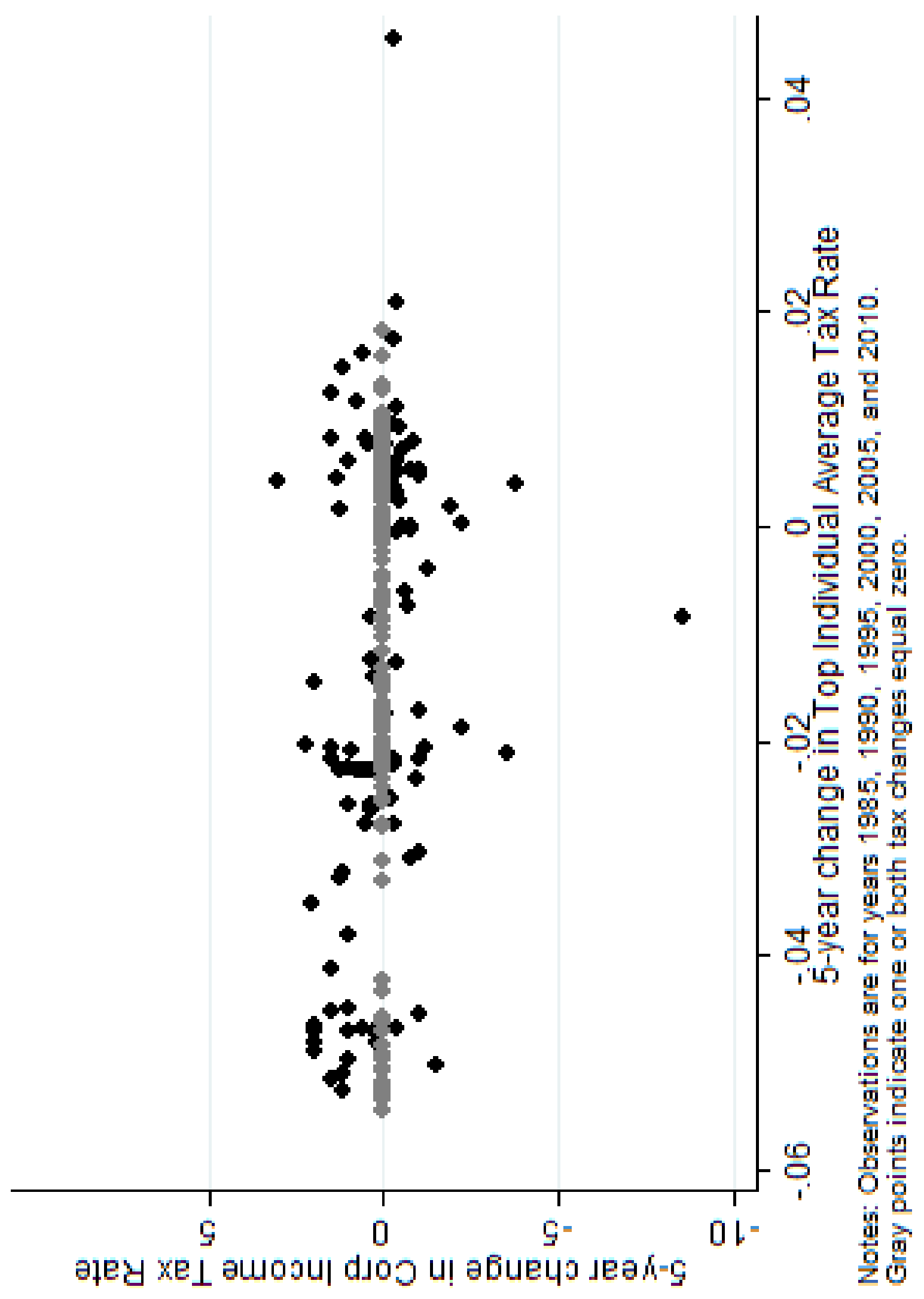


Appendix Figure 4

\section{Example of Downward Bias}
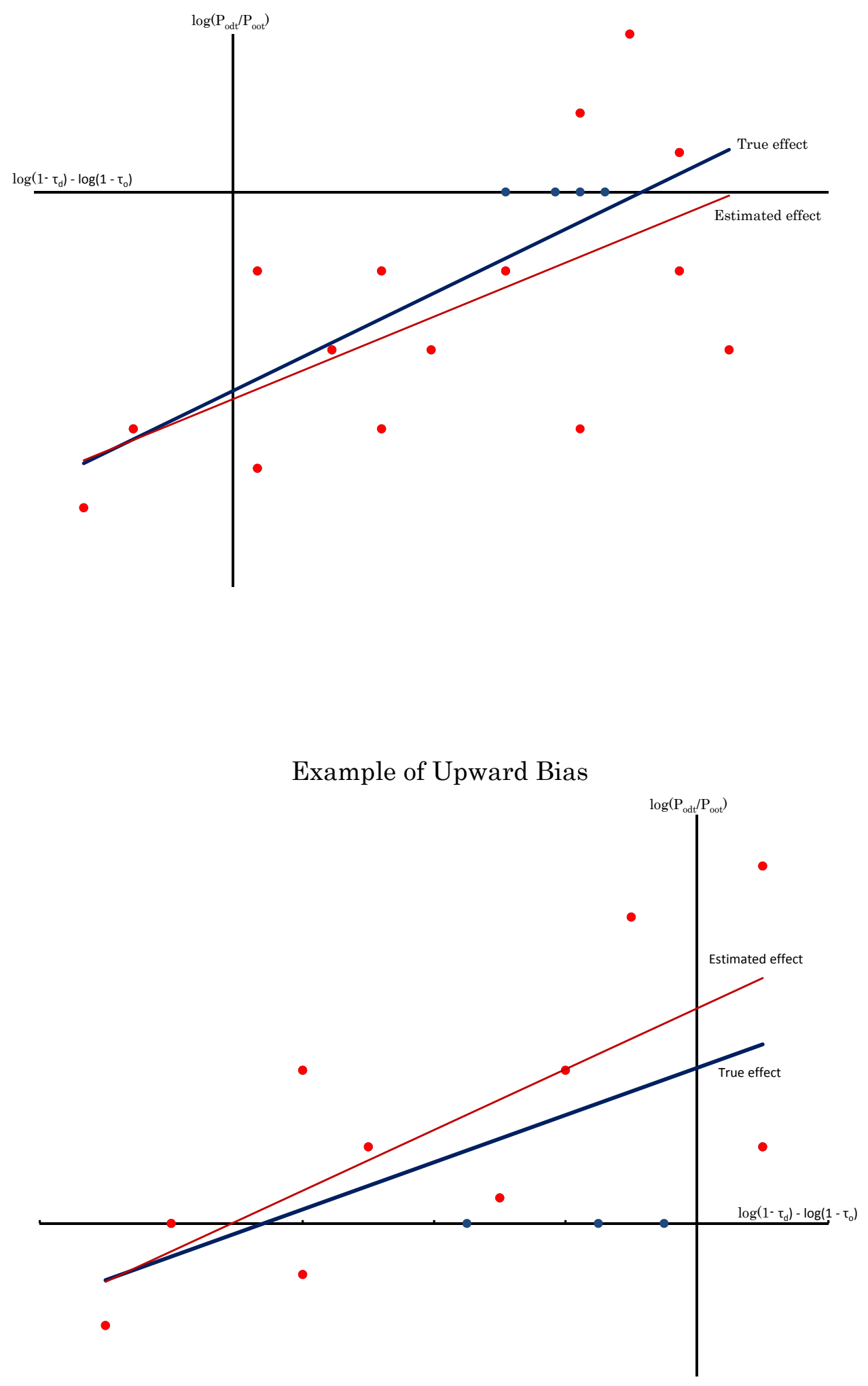

Notes: Each panel shows a hypothetical dataset. Each dot represents an origin-destination-year cell. The three blue points on the x-axis are not observed. The blue line has slope equal to the true effect of tax differentials on mobility. The blue line has the same slope in both panels. The slope of the red line is the estimated effect in the truncated sample. 


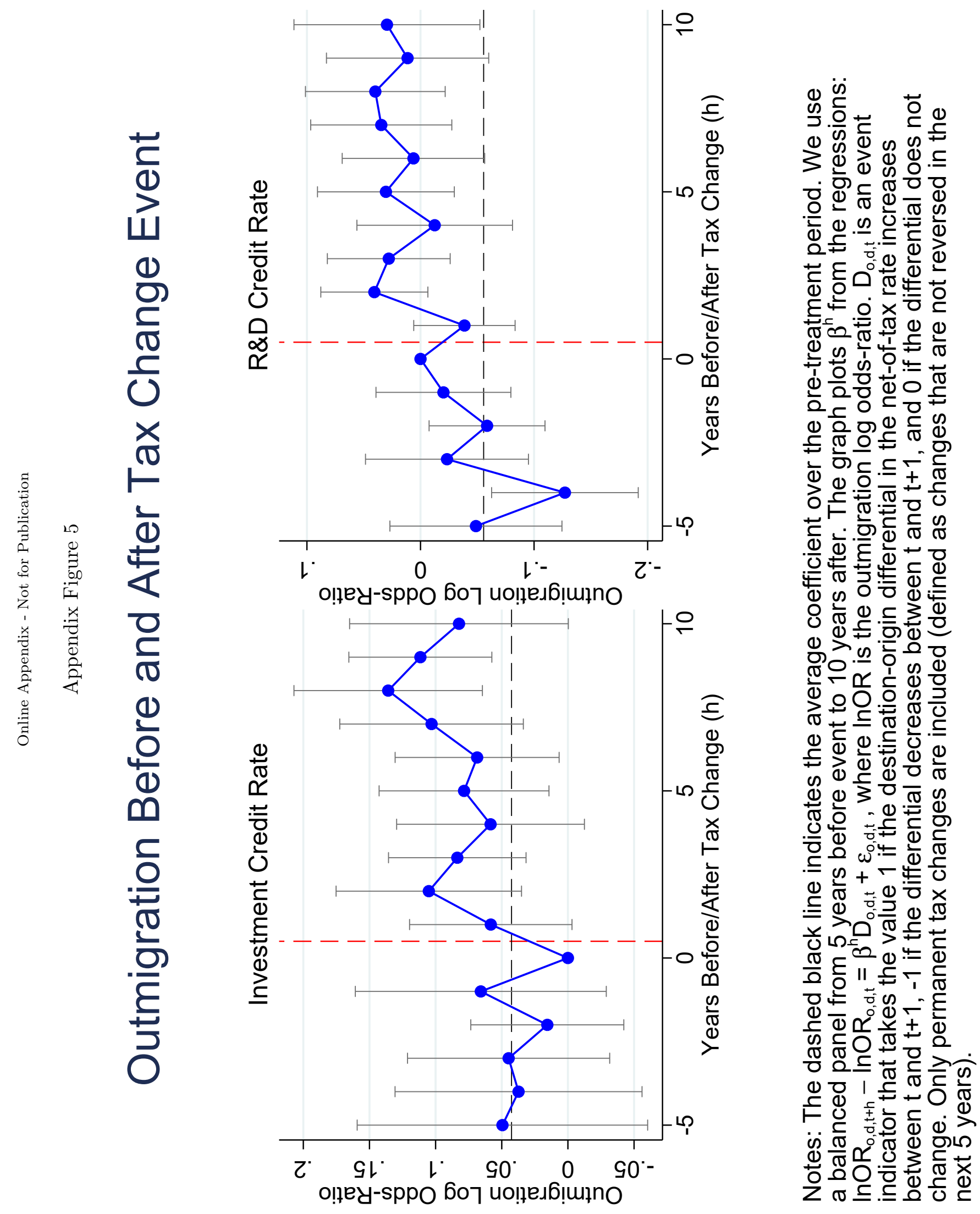




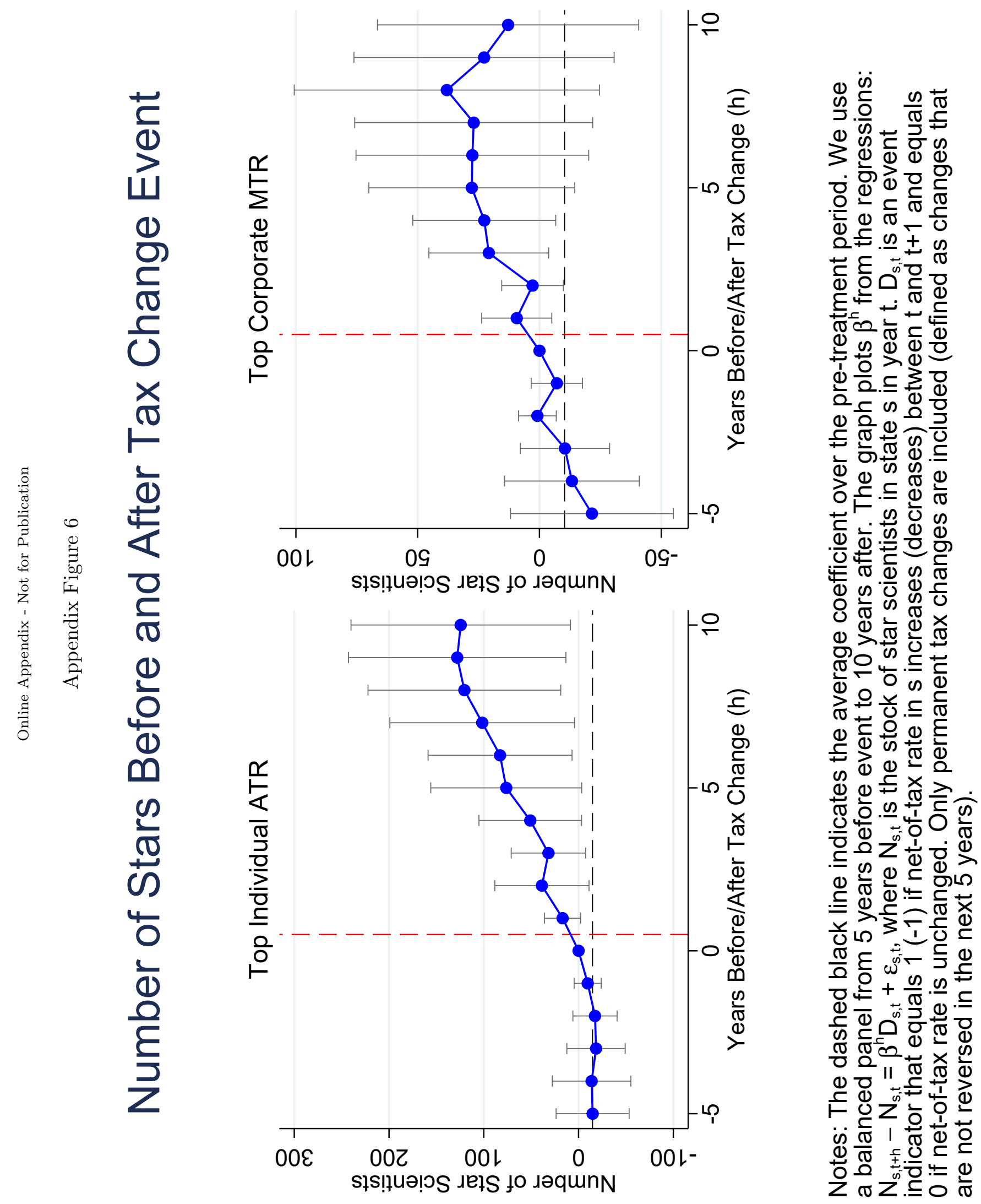




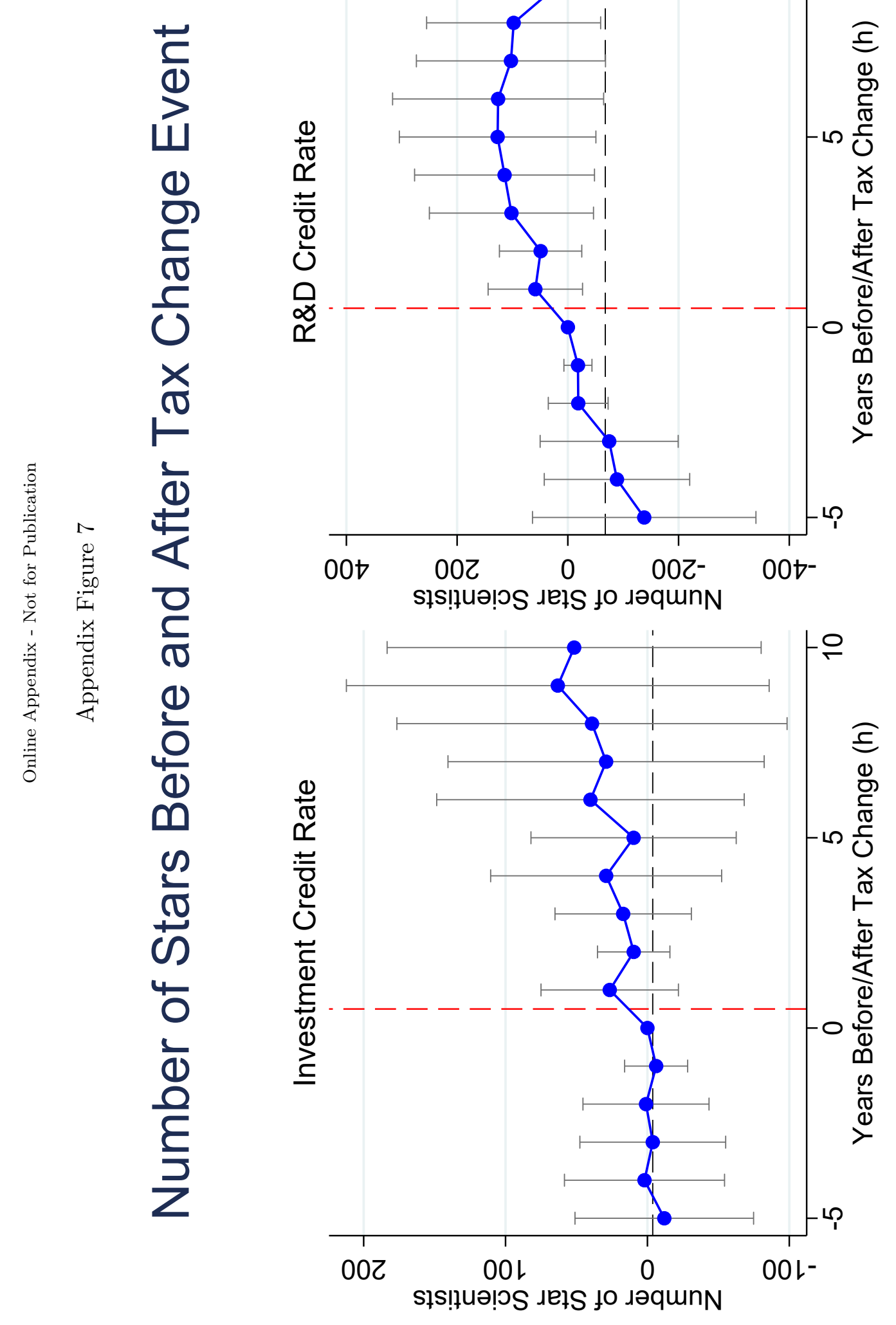

Ф)

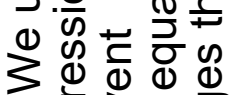

就壾

은 등

क बे

드.

प्रे

证

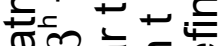

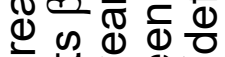

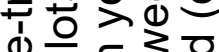

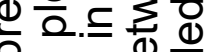

응

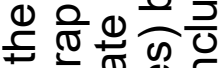

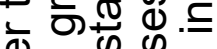

(ब) 0 क 0

ठ․․ \匚

둥

ब㐫舟

正索 $\frac{2}{0}$ 的

क क

元 以

0 交

历ㅇㅇㄴ.

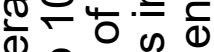

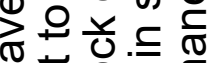

(1) के

Ð0 잉

क)

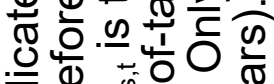

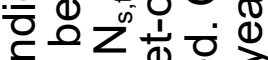

$\because \omega \Phi \stackrel{0}{\omega}$

(1) 준

品

는

$\frac{\pi}{0} \varepsilon \omega^{5}-\subseteq \Phi$

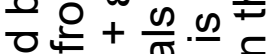

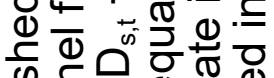

क

중

Q

トU二⿺辶

iं $\frac{1}{\pi}$ ।

बत्र

乙。 
Appendix Figure 8. Impulse Response Functions

\section{Outmigration Response to Investment Credit Change}
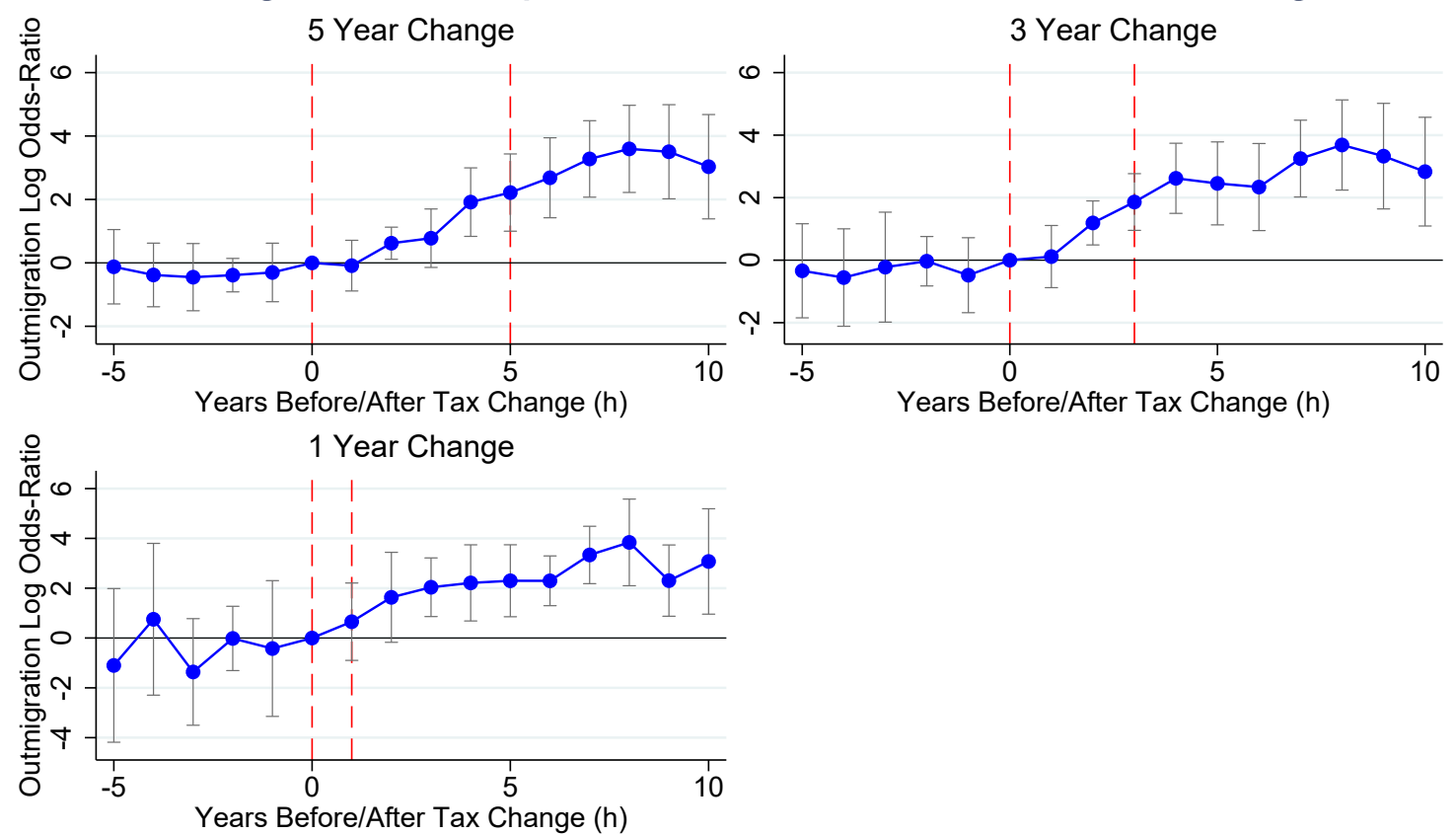

Notes: All regressions use the same sample, a balanced panel from 5 years before event to 10 years after. Graph plots $\beta^{\mathrm{h}}$ from regression: $\ln \mathrm{P}_{\text {odt }+\mathrm{h}}-\ln \mathrm{P}_{\text {odt }}=\beta^{\mathrm{h}}\left(\nabla \mathrm{n}_{\text {odt }+x}-\nabla \mathrm{n}_{\text {odt }}\right)+\mathrm{F}_{\text {odt }}+\varepsilon_{\text {odt }}$, where $\ln P$ is the log odds-ratio of outmigration and $\nabla \mathrm{n}_{\text {odt }}$ is the destination-origin differential in the net-of-tax rate in year $t$, and $x$ is 1,3 , or $5 . F_{\text {odt }}$ is a year fixed effect specific to the region(o)*region(d) pair.

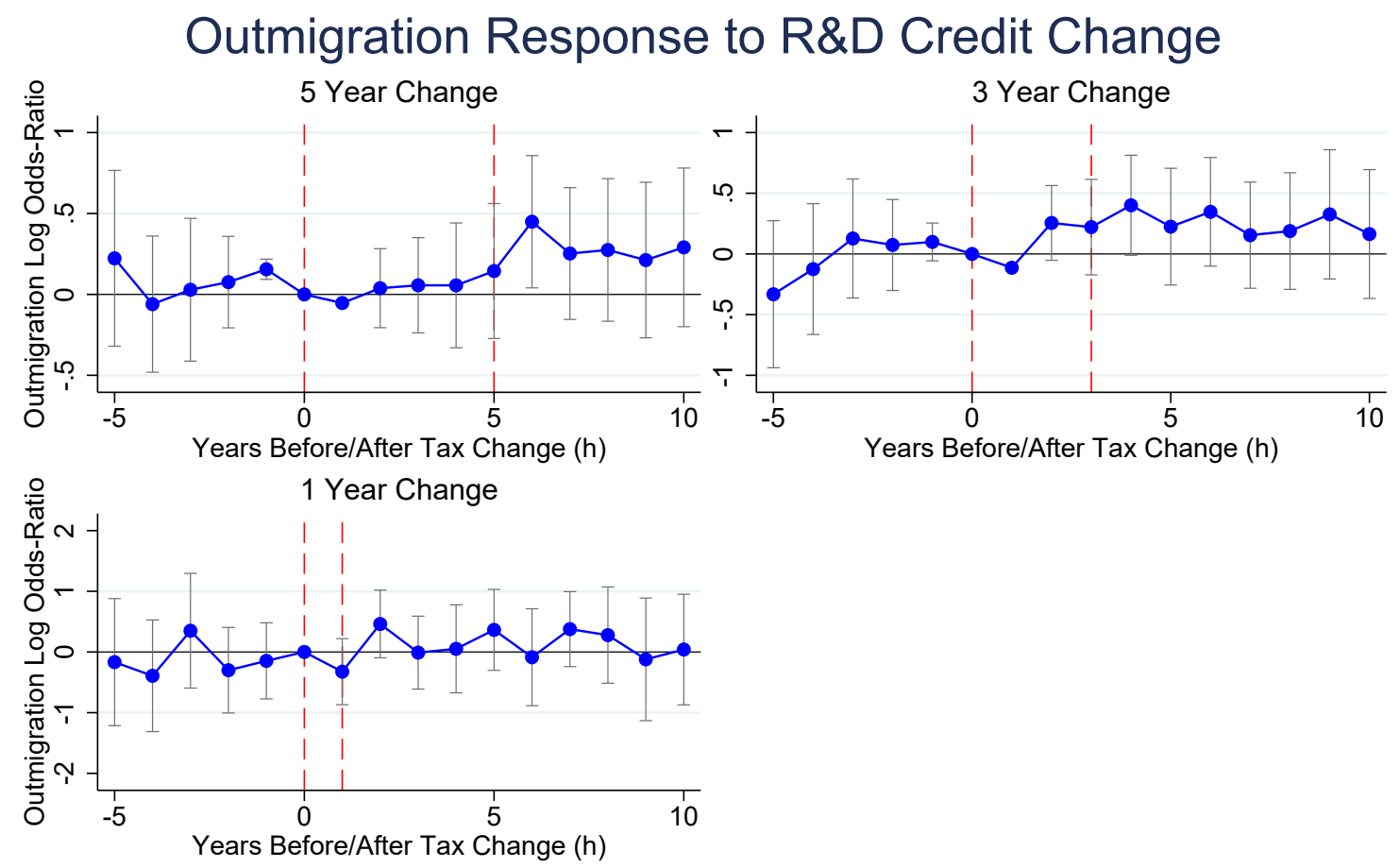

Notes: All regressions use the same sample, a balanced panel from 5 years before event to 10 years after. Graph plots $\beta^{h}$ from regression: $\ln P_{\text {odt }+h}-\ln P_{\text {odt }}=\beta^{h}\left(\nabla n_{\text {odt }+x}-\nabla n_{\text {odt }}\right)+F_{\text {odt }}+\varepsilon_{\text {odt }}$, where $\ln P$ is the log odds-ratio of outmigration and $\nabla n_{\text {odt }}$ is the destination-origin differential in the net-of-tax rate in year $t$, and $x$ is 1,3 , or 5 . $F_{\text {odt }}$ is a year fixed effect specific to the region(o) $)^{*}$ region(d) pair. 